\title{
The Bahamas: Financial Sector Stability Assessment
}

This Financial Sector Stability Assessment on The Bahamas was prepared by a staff team of the International Monetary Fund as background documentation for the periodic consultation with the member country. It is based on the information available at the time it was completed on January 18, 2013. The views expressed in this document are those of the staff team and do not necessarily reflect the views of the government of The Bahamas or the Executive Board of the IMF.

The policy of publication of staff reports and other documents by the IMF allows for the deletion of market-sensitive information.

Copies of this report are available to the public from

International Monetary Fund • Publication Services

$70019^{\text {th }}$ Street, N.W. • Washington, D.C. 20431

Telephone: (202) 623-7430 • Telefax: (202) 623-7201

E-mail: publications@imf.org Internet: http://www.imf.org

\section{International Monetary Fund Washington, D.C.}




\title{
INTERNATIONAL MONETARY FUND
}

\section{THE BAHAMAS}

\section{Financial System Stability Assessment}

\section{Prepared by the Monetary and Capital Markets and Western Hemisphere Department Departments}

\author{
Approved by José Viñals and Saul Lizondo
}

January 18, 2013

This report is based on the work of an IMF Financial Sector Assessment Program (FSAP) mission to The Bahamas during July 17-31, 2012. The team comprised Elie Canetti (mission chief), Elena Loukoianova (deputy mission chief), Ivailo Arsov, Gamal El-Masry, Kalin Tintchev, Laura Valderrama, and Rodolfo Wehrhahn (all IMF), and consultants Richard Britton, Michael Deasy, Vern McKinley, José Tuya, and Christina Urias. Mr. Canetti also participated in the Article IV discussions during October 28-November 2, 2012, including the concluding meeting.

- The Bahamian financial system faces no obvious near-term threats to financial stability. The onshore banking system is well capitalized, liquid, and profitable. Credit risk, particularly for mortgages, will need to be monitored closely in view of existing high non-performing loan (NPL) rates and ongoing economic uncertainties. Stress tests show that the onshore banks can withstand severe shocks to solvency and liquidity.

- The offshore financial sector is very large, with total offshore bank assets equivalent to 75 times GDP at end-2011, although this mainly reflects large treasury operations of global banks intermediated through the system. Interconnections are predominantly between offshore banks and their foreign parents, and strict firewalls protect the domestic economy and financial system from the offshore sector. A lack of detailed data prevented a more complete assessment of this sector, including stress testing or the calculation of financial soundness indicators.

- Financial system oversight has improved greatly over the last decade and the authorities continue to act with resolve on a wide variety of fronts to institute further improvements. However, further strengthening is needed to ensure the financial system remains robust well into the future, particularly in insurance and securities where relatively new legislation is in place, and in pensions, where governing legislation is pending. The offshore sector is supervised on the same principles as the onshore sector, but the vast majority of assets are held in branches and therefore not subject to local capital requirements.

- The crisis management and financial safety net framework has not been tested and is in need of modernization.

The main author of this report is Elie Canetti, with contributions from the members of the team. 
Glossary

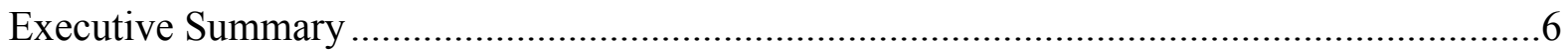

I. Macro-Financial Performance and Structure of the Financial System................................10

A. Macro-Financial Context …………………………..........................................10

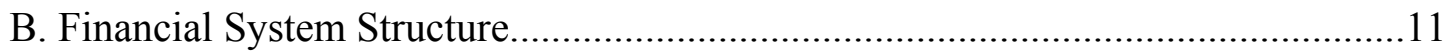

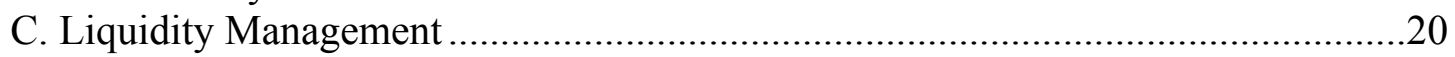

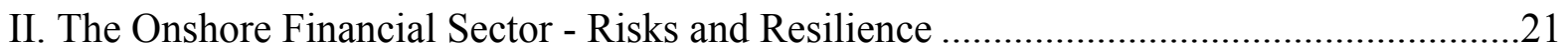

A. Banking Sector ..............................................................................................2

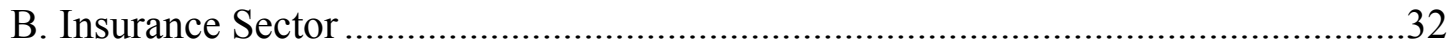

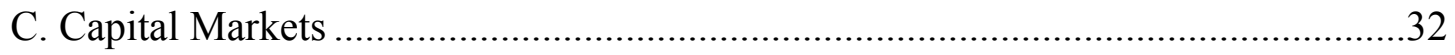

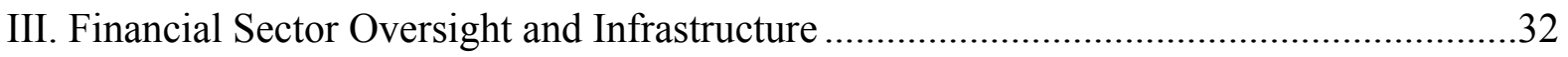

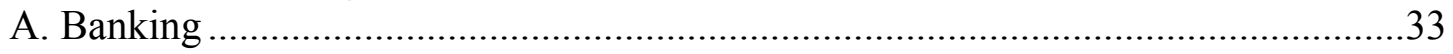

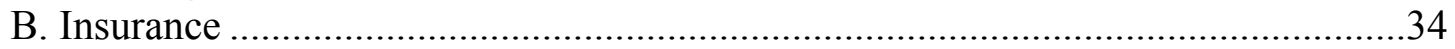

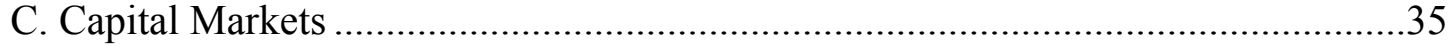

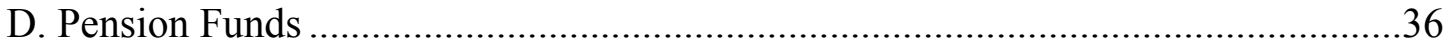

E. Payments and Securities Settlement Systems........................................................36

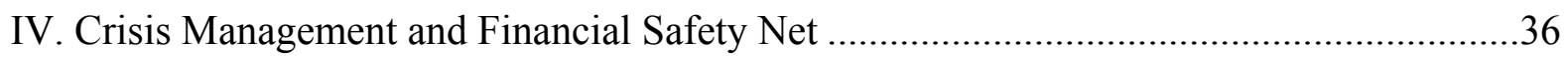

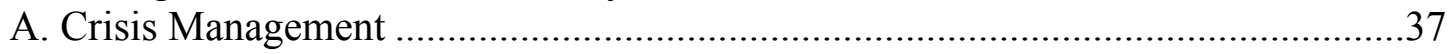

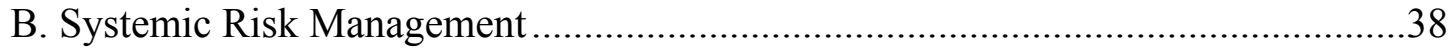

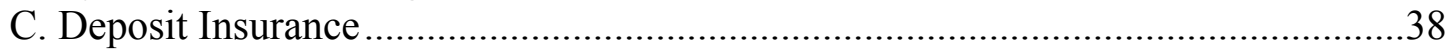

D. Receivership, Resolution, and Liquidation..............................................................39

Tables

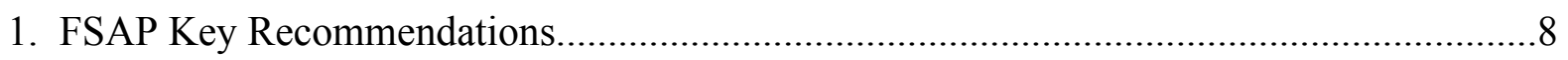

2. Status of Implementation of 2004 OFC Key Recommendations........................................

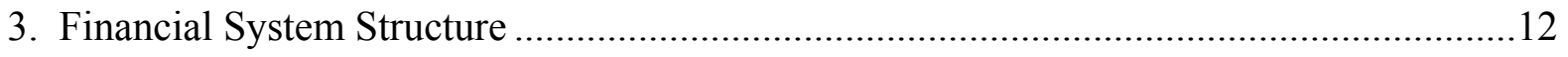

4. Economic Contribution of Banks and Trust Companies ...................................................13

5. Largest Offshore Entities ........................................................................................

6. Summary Stress Test Results: Sensitivity Tests ……………...........................................30

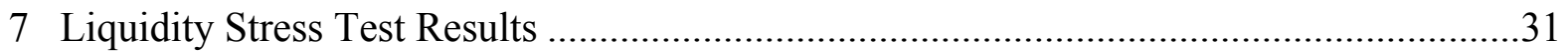

Figures

1. Onshore Banking System Annual Credit Growth...............................................................

2. Assets and Liabilities of the Onshore Commercial Banks................................................15

3. Government securities Investor Base and Maturity Profile.................................................17

4. Investment Funds Licensed or Registered and Assets Under Management ........................18

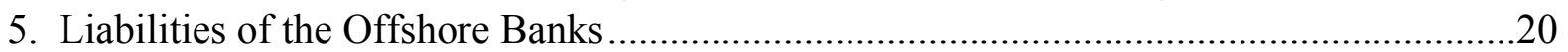


6. Performance of Onshore Commercial Banks ....................................................................22

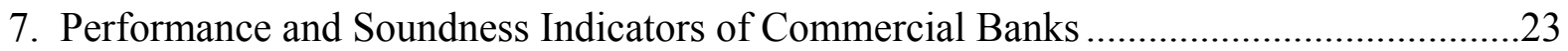

8. Selected Peer Countries: Capital and Return ................................................................24

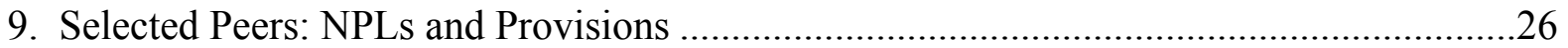

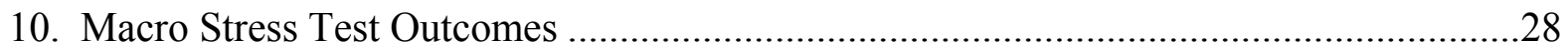

Boxes

1. CLICO Bahamas Liquidation Update and Recommendations ...........................................18

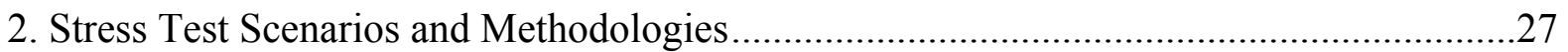

3. Deposit Insurance Corporation (DIC) Operational Recommendations .................................40

Appendices

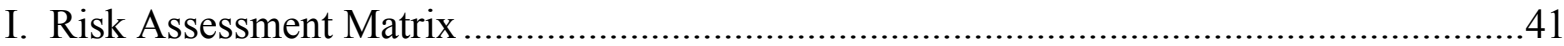

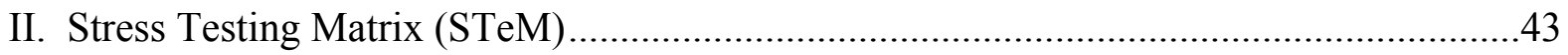

Appendix Tables

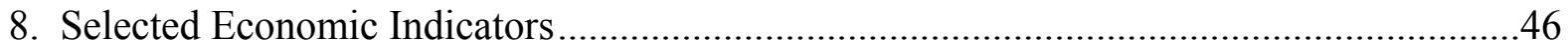

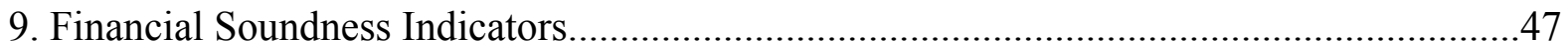

Annexes

Observance of Financial Sector Standards and Codes - Summary Assessments.....................48

I. Basel Core Principles for Effective Banking Supervision................................................49

II. Observance of the IAIS Insurance Core Principles......................................................58

III. Implementation of the IOSCO Objectives and Principles of Securities Regulation .........68

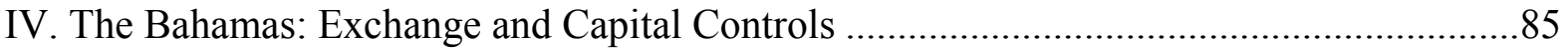

Annex Tables

1. Summary Compliance with the Basel Core Principles-ROSCs ........................................53

2. Recommended Action Plan to Improve Compliance with the Basel Core Principles .........55

3. Summary of Observance of the Insurance Core Principles ..............................................59

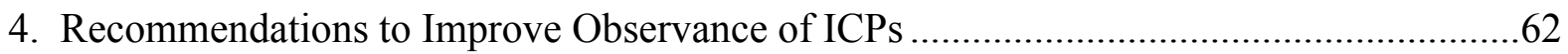

5. Summary Implementation of the IOSCO Principles ……………………......................75

6. Recommended Action Plan to Improve Implementation of the IOSCO Principles...........81 


\section{GLOSSARY}

AML/CFT Anti-Money Laundering and Combating the Financing of Terrorism

AUM

B\$

$\mathrm{BACH}$

BCBS

BCP

BIA

BICA

BISX

bps

BSD

BTCRA

BU

CAIR

CAR

CARTAC

CBBA

CBL

CBoB

$\mathrm{CCB}$

CEL

CEO

CFATF

CFO

CLF

CRA

DIC

ELA

FAQ

FATF

FCSPA

FDI

FIU

FX

FSAP

FSSA

GDP

GFSR

IAASB

IAIS

IASB

IBNRs

ICB
Assets Under Management

Bahamian dollar

The Bahamas Automated Clearing House

Basel Committee on Banking Supervision

Basel Core Principles

The Bahamas Insurance Association

The Bahamas Institute of Chartered Accountants

Bahamas International Securities Exchange

Basis points

Bank Supervision Department

Banks and Trust Companies Regulation Act

Bottom-Up

The Caribbean Association of Insurance Regulators

Capital Adequacy Ratio

Caribbean Regional Technical Assistance Centre

Central Bank of Bahamas Act

CLICO Bahamas Limited

Central Bank of The Bahamas

Compliance Commission of The Bahamas

CLICO Enterprises Limited

Chief Executive Officer

Caribbean Financial Action Task Force

Chief Financial Officer

Colonial Life Financial

Credit Rating Agencies

Deposit Insurance Corporation

Emergency Liquidity Assistance

Frequently Asked Questions

Financial Action Task Force

Financial and Corporate Service Providers Act

Foreign Direct Investment

Financial Intelligence Unit

Foreign Exchange

Financial Sector Assessment Program

Financial System Stability Assessment

Gross Domestic Product

Group of Financial Services Regulators

International Auditing and Assurance Standards Board

International Association of Insurance Supervisors

International Accounting Standards Board

Incurred But Not Reported Claims

Insurance Commission of The Bahamas 


$\begin{array}{ll}\text { ICP } & \text { Insurance Compliance Principle } \\ \text { IFA } & \text { Investment Funds Act 2003 } \\ \text { IFAC } & \text { International Federation of Accountants } \\ \text { IFR } & \text { Investment Funds Regulations } \\ \text { IFRS } & \text { International Financial Reporting Standards } \\ \text { IMF } & \text { International Monetary Fund } \\ \text { IOSCO } & \text { International Organization of Securities Commissions } \\ \text { ISA } & \text { International Standards on Auditing } \\ \text { IT } & \text { Information Technology } \\ \text { MCR } & \text { Minimum Capital Requirement } \\ \text { MMoU } & \text { Multilateral Memorandum of Understanding } \\ \text { MoF } & \text { Ministry of Finance } \\ \text { MoU } & \text { Memorandum of Understanding } \\ \text { NFCMP } & \text { National Financial Crisis Management Plan } \\ \text { NIB } & \text { National Insurance Board } \\ \text { NICB } & \text { National Insurance Crime Bureau } \\ \text { NPL } & \text { Nonperforming Loans } \\ \text { OECD } & \text { Organization for Economic Cooperation and Development } \\ \text { OFC } & \text { Offshore Financial Center } \\ \text { OTC } & \text { Over-the-Counter } \\ \text { PDA } & \text { Protection of Depositors Act } \\ \text { PSA } & \text { Payment Systems Act } \\ \text { QRS } & \text { Quarterly Financial Reporting Ssystem } \\ \text { RAM } & \text { Risk Assessment Matrix } \\ \text { RBS } & \text { Risk-Based Supervision } \\ \text { RFF } & \text { Recognized Foreign Funds } \\ \text { ROA } & \text { Return on Assets } \\ \text { ROE } & \text { Return on Equity } \\ \text { RTGS } & \text { Real-Time Gross Settlement } \\ \text { SCB } & \text { Securities Commission of The Bahamas } \\ \text { SIA } & \text { Securities Industry Act 2011 } \\ \text { SIFI } & \text { Systemically Important Financial Institution } \\ \text { SIR } & \text { Securities Industry Regulations } \\ \text { SMART } & \text { Specific Mandate Alternative Regulatory Test } \\ \text { SRO } & \text { Self Regulatory Organization } \\ \text { SRSC } & \text { Systemic Risk Surveillance Committee } \\ \text { STeM } & \text { Stress Testing Matrix } \\ \text { TD } & \text { Top-down } \\ \text { WEO } & \text { World Economic Outlook } \\ \text { WPC } & \text { Wellington Preserve Corporation } \\ & \end{array}$




\section{EXECUTIVE SUMMARY}

1. The Bahamian financial system weathered the aftermath of the U.S. financial crisis well. This was thanks to very high capitalization and profitability in the domestic banking system, and an improved regulatory framework. However, vulnerabilities exist: the domestic economy is highly dependent on tourism, which could be disrupted by a weakening of the U.S. economy; a prolonged increase in oil prices; or a large-scale hurricane, especially one that destroyed key infrastructure. On the policy front, the main risk stems from the increase in public debt, which has led to recent ratings agency downgrades. Although a fixed exchange rate with the U.S. dollar has been in place since 1970, capital controls afford considerable scope for monetary policy independence.

2. The Bahamian financial system is exceptionally large, reflecting the country's role as a major offshore financial center (OFC). The financial system had total gross assets equivalent to 96 times GDP at end-2011, with total assets of the offshore banking sector equivalent to 75 times GDP. The offshore sector consists mostly of branches or subsidiaries of global financial institutions and pursues a variety of business models. Large treasury operations of global banks intermediated through the Bahamian offshore system are responsible for a significant portion of the sector's balance sheet. The onshore commercial banking sector is well insulated from the offshore sector, and mainly conducts traditional banking activities.

\section{The onshore financial sector is resilient but challenges remain:}

- $\quad$ There is no obvious near-term threat to bank stability, since banks are very well capitalized (both in terms of quantity and quality of capital), profitable, and are not reliant on wholesale funding. High nonperforming loan (NPL) ratios remain the key challenge, particularly on mortgages, which account for over half of NPLs. The authorities remain vigilant about the potential impact on bank capital and have substantially improved credit risk monitoring. Requirements and practices on provisioning and asset impairments are in compliance with international standards. Stress tests confirm that the commercial banks can withstand severe shocks to solvency and liquidity, though banks are heterogeneous in their performance. Contagion risks are contained due to extremely limited interlinkages among onshore commercial banks.

- $\quad$ The insurance sector in The Bahamas is relatively small and has stagnated as confidence was severely affected by the failure of CLICO Bahamas, an insurance company. CLICO is being liquidated, but the liquidation needs to be accelerated.

4. The offshore sector, though large, has a limited impact on the real economy given strict firewalls between the onshore and offshore sectors. Connections between onshore and offshore banks are largely confined to intra-group links and are minimal, with 
only about $1 / 2$ percent of domestic banking sector assets and liabilities with offshore counterparties. Risks in the offshore sector are mitigated by the fact that the vast majority of assets are held by branches of foreign institutions for which solvency risk does not apply at the level of the jurisdiction. In addition, liquidity risks are muted by the fact that the main business models do not entail third-party funding. Nonetheless, a lack of detailed data prevented a more complete assessment of this sector, including stress testing or the calculation of financial soundness indicators.

5. Oversight of the financial system has greatly improved since the 2004 OFC assessment, but there is room for improvement in a range of areas, as recognized by the authorities. Supervisory authorities have implemented or are in the process of implementing a risk-based approach, which may require supporting regulatory changes. Supervision of the offshore sector follows the same principles as the onshore sector, although this sector is dominated by branches that are hence not subject to local capital requirements. Licensing and supervision of offshore entities is supported by effective information sharing with home supervisors and participation in regulatory colleges. Banking supervision is strong. In the securities area, the new Security Industry Act has dealt effectively with most of the issues identified in the 2004 OFC assessment but the current Investment Funds Act 2003 (IFA) and its regulations need to be updated to give the SCB the additional powers required to meet current IOSCO standards. Insurance supervision has significantly improved in recent years but several supervisory and regulatory changes are required to bring regulation in line with international standards.

6. The authorities made a formal commitment to undergo an Anti-Money Laundering and Combating the Financing of Terrorism (AML/CFT) assessment within 18 months after the FSAP mission. The assessment will judge compliance with new Financial Action Task Force (FATF) standards in the context of the Caribbean Financial Action Task Force's (CFATF) next round of evaluations.

7. The current framework for financial crisis management and resolution requires strengthening. To address this, the authorities are developing a National Financial Crisis Management Plan (NFCMP). The mission recommended a variety of additional reforms to improve the capacity to respond to systemic financial shocks. 


\section{Table 1. The Bahamas: FSAP Key Recommendations}

\begin{tabular}{|c|c|}
\hline Recommendations and Authority Responsible for Implementation & Timeframe \\
\hline \multicolumn{2}{|l|}{ Banking sector } \\
\hline Recruit additional staff with particular emphasis on specialists. [CBoB] & Near term \\
\hline Amend legislation so that if Governor is removed, reasons would be publicly disclosed. [CBoB] & Near term \\
\hline $\begin{array}{l}\text { Implement, as planned, draft guidance on bank responsibilities for managing operational, } \\
\text { interest rate, and market risk. [CBoB] }\end{array}$ & Near term \\
\hline Develop guidelines on the scope and methods of consolidated supervision. [CBoB] & Near term \\
\hline \multicolumn{2}{|l|}{ Insurance and Pensions } \\
\hline Introduce a standard methodology for the valuation of long term insurer liabilities. [ICB] & Near term \\
\hline $\begin{array}{l}\text { Implement fully the } 3 \text { year plan towards risk-based supervision (RBS). In particular, onsite } \\
\text { comprehensive examinations should be initiated without delay. [ICB] }\end{array}$ & Medium term \\
\hline Develop support for consumer complaint handling. Consider establishing ombudsman. [ICB] & Medium term \\
\hline $\begin{array}{l}\text { Amend legislation to specifically require intermediaries to establish a premium payment trust } \\
\text { account separate from the intermediary's account. [ICB] }\end{array}$ & Near term \\
\hline $\begin{array}{l}\text { Introduce staggered terms for Insurance Commission of The Bahamas (ICB) Board and publish } \\
\text { reasons for removal of Board members or the Superintendent. [Government] }\end{array}$ & Near term \\
\hline $\begin{array}{l}\text { Develop regulations for appropriate group supervision, corporate governance and risk } \\
\text { management standards, processes and procedures and conduct onsite reviews in accordance } \\
\text { with Insurance Core Principle (ICP) } 23 \text {. [ICB] }\end{array}$ & Near term \\
\hline Promulgate regulation for new pension fund legislation without delay. [Government] & Near term \\
\hline \multicolumn{2}{|l|}{ Capital Markets } \\
\hline Replace current IFA and its regulations. [Government] & Near term \\
\hline $\begin{array}{l}\text { Delete the exclusion in the Securities Industry Act } 2011 \text { (SIA) which permits selling investment } \\
\text { fund shares to clients without a license as long as that is the only securities business a person } \\
\text { undertakes. [SCB] }\end{array}$ & Near term \\
\hline $\begin{array}{l}\text { Subject all locally resident related parties to full due diligence check in licensing investment } \\
\text { fund. Subject managers/advisers, operators and custodians to ongoing oversight. [SCB] }\end{array}$ & Near term \\
\hline $\begin{array}{l}\text { Consider appointing a public interest oversight body for the auditing profession and The } \\
\text { Bahamas Institute of Chartered Accountants (BICA), possibly giving the role to the Securities } \\
\text { Commission of The Bahamas (SCB). [Government] }\end{array}$ & Near term \\
\hline Develop a plan, possibly as part of the NFCMP, to deal with the failure of a licensee. [SCB] & Near term \\
\hline \multicolumn{2}{|l|}{ Safety Net and Crisis Management } \\
\hline $\begin{array}{l}\text { Prepare crisis management plan draft for Ministry of Finance (MoF). [CBoB and other } \\
\text { regulatory agencies] }\end{array}$ & Near term \\
\hline Implement crisis management plan. [CBoB jointly with other regulatory agencies] & Medium term \\
\hline $\begin{array}{l}\text { Develop a category of 'systemic banks' narrowed to those eligible for solvency support or } \\
\text { extraordinary intervention, consistent with international practice. [CBoB] }\end{array}$ & Near term \\
\hline $\begin{array}{l}\text { Develop a target ratio for Deposit Insurance Corporation (DIC) equity capital and determine } \\
\text { primary and secondary borrowing sources. [CBoB and DIC] }\end{array}$ & Near term \\
\hline
\end{tabular}




\section{Table 2. The Bahamas: Status of Implementation of 2004 OFC Key Recommendations}

\begin{tabular}{|c|c|}
\hline Key Recommendations of the 2004 OFC Assessment & Status \\
\hline \multicolumn{2}{|l|}{ General } \\
\hline Consolidate the reporting lines for the regulatory authorities under the MoF & Implemented \\
\hline $\begin{array}{l}\text { Complete the comprehensive review of the overall regulatory framework to determine } \\
\text { the most efficient structure for the local environment }\end{array}$ & Ongoing \\
\hline $\begin{array}{l}\text { Introduce statutory protection against civil and criminal liability for all staff of, and } \\
\text { official appointees to, the regulatory authorities, while performing their duties in good } \\
\text { faith }\end{array}$ & Implemented \\
\hline \multicolumn{2}{|l|}{ Banking } \\
\hline $\begin{array}{l}\text { Clarify the extent to which the branches and subsidiaries of foreign banks may pass } \\
\text { information to their head office and parent bank for consolidated risk management and } \\
\text { supervisory purposes }\end{array}$ & Implemented \\
\hline $\begin{array}{l}\text { Establish a properly resourced policy unit within the Bank Supervision Department } \\
\text { (BSD) and address the issues on which action is required }\end{array}$ & Implemented \\
\hline \multicolumn{2}{|l|}{ Securities } \\
\hline $\begin{array}{l}\text { Narrow the powers of the minister to dismiss members of the Securities Commission } \\
\text { so that just cause is the grounds for dismissal }\end{array}$ & Implemented \\
\hline $\begin{array}{l}\text { Complete the work on the draft mutual funds law and on the amendments to the } \\
\text { securities legislation and present to parliament as soon as possible }\end{array}$ & Implemented \\
\hline $\begin{array}{l}\text { Establish a clear policy with respect to the confidentiality declaration required from } \\
\text { overseas regulators in order to permit efficient exchanges of information in line with } \\
\text { the practice adopted by the CBoB }\end{array}$ & $\begin{array}{l}\text { Implemented } \\
\text { This and related issues resolved by } \\
\text { the SIA }\end{array}$ \\
\hline \multicolumn{2}{|l|}{$A M L / C F T$} \\
\hline Ratify all the relevant international conventions & Implemented $^{1}$ \\
\hline $\begin{array}{l}\text { Enact legislation to criminalize and make other provisions in relation to the financing of } \\
\text { terrorism }\end{array}$ & $\begin{array}{l}\text { Implemented } \\
\text { The Anti-Terrorism Act was } \\
\text { enacted in } 2004\end{array}$ \\
\hline $\begin{array}{l}\text { Rationalize the legal framework with respect to money laundering in order to reduce } \\
\text { the number of highly prescriptive requirements and to permit financial institutions to } \\
\text { develop a risk-based approach }\end{array}$ & Implemented \\
\hline $\begin{array}{l}\text { Reduce the number of exceptions to the high level principle of requiring financial } \\
\text { institutions to identify their customers }\end{array}$ & Implemented \\
\hline $\begin{array}{l}\text { Extend the time permitted to financial institutions to undertake the process of customer } \\
\text { identification on pre- } 2000 \text { Bahamian dollar accounts, and consider introducing a risk- } \\
\text { based approach to resolving the outstanding accounts }\end{array}$ & Implemented \\
\hline $\begin{array}{l}\text { Revise the provisions relating to the obligation to identify beneficial } \\
\text { owners/beneficiaries of corporate entities, trusts, partnerships, etc., to ensure that the } \\
\text { legal requirements present no exceptions }\end{array}$ & Implemented \\
\hline $\begin{array}{l}\text { Review the list of countries and institutions that underpin the "eligible introducer" } \\
\text { provisions to ensure that they do not weaken the customer identification requirements }\end{array}$ & Implemented \\
\hline \multicolumn{2}{|c|}{$\begin{array}{l}{ }^{1} \text { The following United Nations (UN) Conventions have been ratified: (i) the International Convention for the Suppression of } \\
\text { the Financing of Terrorism (October, 2005); (ii) UN Convention against Transnational Organized Crime (September, 2008); } \\
\text { (iii) Protocol Against the Smuggling of Migrants by Land, Sea and Air, supplementing the UN Convention Against } \\
\text { Transnational Organized Crime and the Protocol to Prevent, Suppress and Punish Trafficking in Persons, especially Women } \\
\text { and Children, supplementing the UN Convention Against Transnational Organized Crime (September, 2008); (iv) Protocol } \\
\text { Against the Illicit Manufacturing of and Trafficking in Firearms, Their Parts and Components and Ammunition, supplementing } \\
\text { the UN Convention Against Transnational Organized Crime (September, 2008); and (v) the Inter-American Convention on } \\
\text { Mutual Legal Assistance in Criminal Matters (2009). }\end{array}$} \\
\hline
\end{tabular}




\section{Macro-Financial Performance and Structure of the Financial System}

\section{A. Macro-Financial Context}

8. The Bahamian economy has continued its recovery from the first wave of the global financial crisis. The economy has gradually picked up after a 5 percent decline in output in 2009 and GDP is expected to grow at about 2.5 percent in 2012, thanks to a rebound in tourism and large investment projects (see Appendix Table 8). The external current account deficit is expected to widen further during 2012-14, mainly reflecting considerable foreign direct investment (FDI)-related imports, notably in connection with the US $\$ 3.5$ billion Baha Mar project. However, reserves remained reasonably strong at US\$829 million at end-2012. ${ }^{1}$

\section{Downside risks center in the tourism sector, on which the economy is highly} dependent. Tourism is vulnerable to a weakening of the U.S. economy; a prolonged increase in oil prices; or a large-scale hurricane, especially one that destroyed key infrastructure. The recent increase in central government debt, which is expected to reach 54 percent of GDP by the end of FY 2012/13, constitutes a further potential source of risk, although the government has expressed its commitment to fiscal consolidation.

10. Monetary policy is centered on a fixed exchange rate with the U.S. dollar, while capital controls afford considerable scope for policy independence. ${ }^{2}$ After holding the discount rate steady for six years, the Central Bank of the Bahamas (CBoB) lowered it by 75 basis points to 4.5 percent in June 2011 - against a background of subdued price pressures and an adequate reserves position — with a view to providing additional support to the struggling recovery. ${ }^{3}$

11. Domestic credit growth has weakened in recent years. It fell to 1 percent in 2011 from a peak of 14.3 percent in 2006 (Figure 1), reflecting the impact of the recession. The composition has shifted towards credit to the public sector, as the government expanded securities issuance to fund its fiscal needs. Holdings of government securities and loans to the public sector have increased to 14 percent of total bank assets in 2011 from 7 percent in 2006. More than 80 percent of total public debt is domestic and it is largely held to maturity by commercial banks, public corporations, and pension funds.

\footnotetext{
${ }^{1}$ Equivalent to two months of imports of goods and services. Gross international reserves covered 100.4 percent of reserve money at end-2011, well above the required legal minimum of 50 percent.

${ }^{2}$ The Bahamian dollar (B\$) has been set at parity with the U.S. dollar since 1970. See Annex IV for a detailed description of exchange and capital controls in The Bahamas.

${ }^{3}$ Reserve requirements have been unchanged for decades and the $\mathrm{CBoB}$ has not used direct credit controls on banks since August 2004.
} 
Figure 1. The Bahamas: Onshore Banking System Annual Credit Growth

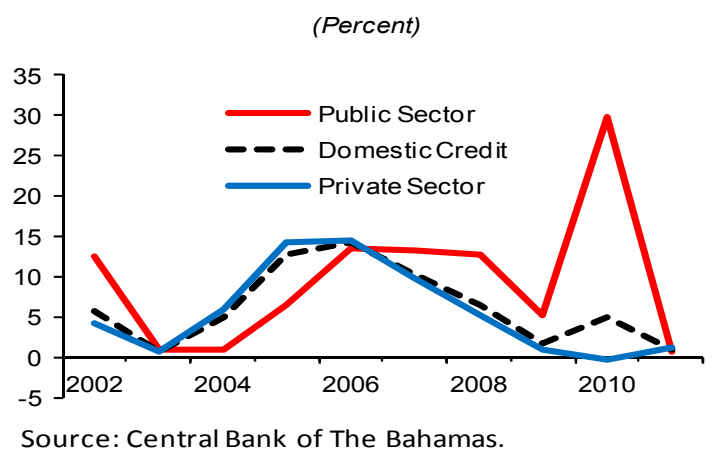

B. Financial System Structure

12. The Bahamian financial system is large, reflecting the country's longstanding status as a major OFC (Table 3). ${ }^{4}$ Total gross assets in the system were equivalent to 96 times GDP at end-2011. The Bahamas has one securities exchange with 19 issuers and capitalization of around 35 percent of GDP. There is no derivatives market. At end-2011, there were 271 banks and trust companies with active licenses, of which 155 were restricted (mainly nominee trust companies). ${ }^{5}$ Banks licensed in The Bahamas held US\$595 billion in assets, with offshore banks accounting for 98 percent of the total. The overwhelming majority of assets are located outside The Bahamas, although some 80 percent of the assets of the onshore commercial banks are domestic.

13. The economic contribution of the financial sector to the economy is significant. It is responsible for about 15 percent of GDP and some 9 percent of tax receipts, although the banking sector directly accounts for only 2.5 percent of overall employment. ${ }^{6}$ Most of the contribution comes from the onshore sector, despite its relatively small size in terms of assets. Offshore banking contributes less than 3 percent of GDP, employs only about

\footnotetext{
${ }^{4}$ Based on the BIS International Banking Statistics (as of December 2011), The Bahamas is the fourth largest OFC by assets after the Cayman Islands, Hong Kong SAR, and Singapore.

${ }^{5}$ There is a multiplicity of types of licenses for banking institutions. 8 Authorized Dealers (commercial banks) carry on business in The Bahamas and deal in Bahamian dollars. 83 Non-Resident Banks operating under public licenses are mainly subsidiaries and branches of international banks and carry on offshore activities only, including trust services, wealth management and group treasury activities. 4 Restricted License Banks carry on business only with specified persons. 10 Authorized Agents have only a limited presence in The Bahamas and are managed by a resident bank in The Bahamas. 6 Non-Active banks are in the course of voluntary wind-up.

${ }^{6}$ The main sources of government revenues from the financial sector are stamp taxes, license and registration fees and work permit fees for non-Bahamian residents.
} 
Table 3. The Bahamas: Financial System Structure

\begin{tabular}{|c|c|c|c|c|c|c|c|c|}
\hline & \multirow[t]{2}{*}{ Number } & \multicolumn{3}{|c|}{$\begin{array}{l}\text { Assets } 5 / \\
\text { (B\$ billion) }\end{array}$} & \multicolumn{3}{|c|}{$\begin{array}{l}\text { Assets Relative to } 2011 \text { GDP } \\
\text { (Percent) }\end{array}$} & \multirow{2}{*}{$\begin{array}{r}\text { Assets Relative } \\
\text { to Total Financial } \\
\text { System Assets } \\
\text { (Percent) }\end{array}$} \\
\hline & & Domestic & Foreign & Total & Domestic & Foreign & Total & \\
\hline Banks 1/ & 91 & 9.7 & 585.4 & 595.1 & 125 & 7,517 & 7,642 & 79.6 \\
\hline \multicolumn{9}{|l|}{ Of which: } \\
\hline Onshore Commercial Banks & 8 & 9.7 & 2.4 & 12.1 & 125 & 30 & 155 & 1.6 \\
\hline Domestically Owned & 3 & 2.7 & 0.1 & 2.8 & 35 & 1 & 35 & 0.4 \\
\hline Foreign Owned & 5 & 7.0 & 2.3 & 9.3 & 90 & 30 & 120 & 1.3 \\
\hline Subsidiaries & 4 & 6.9 & 2.3 & 9.2 & 89 & 30 & 119 & 1.2 \\
\hline Branches 2/ & 1 & 0.1 & n.a. & 0.1 & 1 & n.a. & 1 & 0.0 \\
\hline Offshore Banks & 83 & -- & 583.0 & 583.0 & -- & 7,486 & 7,486 & 78.0 \\
\hline $\begin{array}{l}\text { Other Local Financial } \\
\text { Institutions } 3 /\end{array}$ & 10 & 0.1 & 2.8 & 2.9 & 1 & 36 & 38 & 0.4 \\
\hline Offshore Public Trusts & 15 &.-- & 59.7 & 59.7 & -- & 767 & 767 & 8.0 \\
\hline Restricted banks and Trusts 4/ & 21 & n.a. & n.a. & n.a. & n.a. & n.a. & n.a. & \\
\hline Nominee Trusts & 134 & n.a. & n.a. & n.a. & n.a. & n.a. & n.a. & \\
\hline Insurers & 100 & 1.3 & 1.2 & 2.5 & 17 & 15 & 32 & 0.3 \\
\hline \multicolumn{9}{|l|}{ Of which: } \\
\hline Domestic Insurers & 72 & 1.3 & -- & 1.3 & 17 & -- & 17 & 0.2 \\
\hline Property and Liability & 11 & 0.4 & -- & 0.4 & 5 & -- & 5 & 0.1 \\
\hline Life and health & 11 & 1 & -- & 1 & 13 & -- & 13 & 0.1 \\
\hline Agents and Brokers & 50 & -- & -- & n.a. & -- & -- & n.a. & \\
\hline External Insurers & 28 & -- & 1.2 & 1.2 & -- & 15 & 15 & 0.2 \\
\hline Captive Insurers & 12 & -- & n.a. & n.a. & -- & n.a. & n.a. & \\
\hline Non-captive Insurers & 7 & -- & n.a. & n.a. & -- & n.a. & n.a. & \\
\hline Insurance Managers & 5 & -- & n.a. & n.a. & -- & n.a. & n.a. & \\
\hline Intermediaries & 4 & -- & n.a. & n.a. & n.a. & n.a. & n.a. & \\
\hline Pension Funds & n.a. & n.a. & n.a. & n.a. & n.a. & n.a. & n.a. & \\
\hline Credit Unions & 10 & 0.3 & -- & 0.3 & 3 & -- & 3 & 0.0 \\
\hline Investment Funds & 713 & -- & 86.8 & 86.8 & -- & 1,114 & 1,114 & 11.6 \\
\hline Others & n.a. & n.a. & n.a. & n.a. & n.a. & n.a. & n.a. & \\
\hline Total 5/ & & 11.4 & 735.9 & 747.3 & 146 & 9,450 & 9,596 & 100.0 \\
\hline \multicolumn{9}{|l|}{ Memo item: } \\
\hline Gross Domestic Product in 2011 & & & & 7.8 & & & & \\
\hline
\end{tabular}

Sources: Bankscope; Central Bank of The Bahamas, Company accounts; The Insurance Commission of The Bahamas; IMF(WEO); IMF staff estimates.

1/ Institutions licensed as a public bank or a public bank and trust in The Bahamas.

2. The foreign branch operating as a commercial bank in The Bahamas has significant foreign assets but because of its business model these foreign assets are reported in the assets of the offshore banks.

$3 /$ Banks and trusts registered as resident financial institutions but that deal mainly with non-residents and savings and loan institutions that deal only in Bahamian dollars.

4/ A restricted bank, bank and trust, or trust is an institution permitted to carry on business only for specified persons usually named in its license.

5/ Assets and number of institutions are at end-2011 or latest available: banks, other local financial institutions and trusts are at end-2011; number of insurance companies at end-2011 and insurance companies' assets at end-2010; credit unions are at end-2010; investment funds' assets under management are at end-2009 and number of funds are at June 2011.

Notes:

--indicates that the entity does not hold the type of assets.

n.a. indicates that data is not available. 
$1 / 2$ percent of the labor force, and contributes less than 1 percent of GDP to government revenues, as it does not operate in the mortgage market that garners most of the stamp taxes (Table 4).

Table 4. The Bahamas: Economic Contribution of Banks and Trust Companies (In B \$ Million)

\begin{tabular}{|c|c|c|c|c|c|c|c|c|c|}
\hline & 2003 & 2004 & 2005 & 2006 & 2007 & 2008 & 2009 & 2010 & 2011 \\
\hline & \multicolumn{9}{|c|}{ Onshore } \\
\hline Employment 1/ & 3,208 & 3,275 & 3,424 & 3,557 & 3,766 & 3,791 & 3,689 & 3,716 & 3,705 \\
\hline Salaries & 129.5 & 133.7 & 142.5 & 151.3 & 167.4 & 182.3 & 163.8 & 171.8 & 171.2 \\
\hline Government Fees & 6.7 & 7.6 & 8.8 & 8.6 & 8.9 & 8.9 & 14.8 & 14.5 & 19.9 \\
\hline Capital Expenditure & 11.9 & 28 & 12.5 & 16.3 & 18.3 & 24.2 & 16.4 & 20.6 & 15.6 \\
\hline \multirow[t]{2}{*}{ Total Expenditure } & 237.2 & 288.9 & 266.2 & 291.9 & 307.7 & 347.9 & 329.2 & 349.7 & 363.6 \\
\hline & \multicolumn{9}{|c|}{ Offshore } \\
\hline Employment 1/ & 1,045 & 1,068 & 1,027 & 1,134 & 1,223 & 1,220 & 1,216 & 1,192 & 1,090 \\
\hline Salaries & 66.4 & 74.2 & 68.6 & 75.7 & 107.3 & 107.9 & 116.9 & 114.8 & 117 \\
\hline Government Fees & 9.7 & 11.3 & 9.2 & 9.6 & 10.4 & 10.7 & 11.2 & 10.7 & 9.0 \\
\hline Capital Expenditure & 3.6 & 6.7 & 5.1 & 10.7 & 9.4 & 9.0 & 4.6 & 4.2 & 6.8 \\
\hline Total Expenditure & 159.6 & 170.5 & 159.7 & 182 & 215.7 & 222.6 & 225 & 232 & 231.7 \\
\hline \multicolumn{10}{|l|}{ Memorandum } \\
\hline Total employment $1 /$ & 154,965 & 158,340 & 161,789 & 165,312 & 168,912 & 172,591 & 176,350 & 180,191 & 184,115 \\
\hline Private consumption & 4,488 & 4,629 & 5,116 & 5,470 & 5,600 & 5,791 & 5,413 & 5,594 & 6,136 \\
\hline Gross private fixed capital & 1,377 & 1,341 & 1,757 & 2,186 & 2,086 & 1,777 & 1,605 & 1,400 & 1,636 \\
\hline General government taxes & 815 & 831 & 925 & 1,094 & 1,197 & 1,267 & 1,130 & 1,109 & 1,282 \\
\hline Nominal GDP & 6,954 & 7,100 & 7,719 & 7,974 & 8,319 & 8,239 & 7,806 & 7,700 & 8,074 \\
\hline
\end{tabular}

Source: The Central Bank of The Bahamas.

$1 /$ Number of employees

14. The domestic (onshore) banking sector and the international (offshore) financial center are effectively segmented. Intra-group lending operations are very modest and offshore entities are prohibited from holding balances in Bahamian dollars except to finance local expenses, cannot invest in domestic securities and have limited exposure to domestic real estate markets given strict capital controls. Any lending facility offered to non-residents and secured by Bahamian dollar assets is subject to explicit authorization by the CBoB. ${ }^{7}$ Onshore commercial banks are allowed to deal in B \$, but their foreign exchange (FX) transactions with residents are restricted within limits established under delegated authority from the central bank. ${ }^{8}$ Intra-group lending between the onshore and offshore sectors consists of a single onshore commercial bank that provides liquidity to two offshore affiliates (in

\footnotetext{
${ }^{7}$ Offshore banks do not conduct business with Bahamian residents, but they can provide mortgages to nonresidents that wish to purchase residential real estate in The Bahamas.

${ }^{8}$ The current limit on net FX open positions for onshore commercial banks is the lower of 5 percent of Tier 1 capital or US\$5 million.
} 
compliance with statutory prudential rules). ${ }^{9}$ Direct ownership links between the offshore and onshore sectors are extremely limited. Commercial banks and other credit institutions need exchange control approval to make loans to residents in foreign currency.

15. Prudential rules apply equally to the onshore and offshore sectors, including on capital adequacy, liquidity, and large exposure ratios. However, capital adequacy rules do not apply to the large majority (by assets) of the offshore sector since well over 90 percent of the assets of the offshore sector are held in branches. All offshore entities must be licensed under regulations that include requirements for verifying that new licensees are subject to home country consolidated supervision and that the home country supervisor concurs with the establishment of the new licensee in The Bahamas. The $\mathrm{CBoB}$ maintains at least annual contact with home regulators of parent institutions and home regulators are invited to inform the $\mathrm{CBoB}$ of any information that should be highlighted to it. Licensees are required to prepare financial reports on a consolidated basis and the $\mathrm{CBoB}$ contacts either the licensee or the overseas regulator should any material concerns arise.

\section{Onshore financial sector}

16. Foreign-owned banks account for over three quarters of the onshore commercial banking sector's assets. Of the eight onshore commercial banks, three are domestically owned while there are four subsidiaries and one branch of foreign banks. The sector is fairly concentrated with the three largest banks holding 68 percent of total assets.

\section{Commercial banks are primarily funded by deposits and equity (71 percent and} 18 percent respectively). Capital and interbank market funding is currently negligible. The share of equity funding has increased since 2003, partly due to conversion of foreign branches into subsidiaries, which resulted in liquidity provision from parents being converted into capital.

\section{The commercial banks engage in traditional banking activities, primarily} providing residential mortgages and consumer finance to Bahamian residents. The share of credit in banks' assets was roughly 75 percent at end-2011, more than 90 percent of which was to the private sector (Figure 2). Domestic residential mortgages accounted for 41 percent of total loans to residents at end-2011. Exposure to the public sector has increased significantly since 2008 to 14 percent of total assets, driven primarily by lending to the central government. In the absence of a secondary market, two-thirds of government securities are held to maturity, mitigating market risks for banks. There is some evidence of rapid credit growth from credit unions and retailers, albeit from a very low base.

\footnotetext{
${ }^{9}$ The onshore entity has a net exposure to these two affiliates that has averaged 5.5 percent of its total assets over Q1 2006 through Q1 2012.
} 


\section{Figure 2. The Bahamas: Assets and Liabilities of the Onshore Commercial Banks}
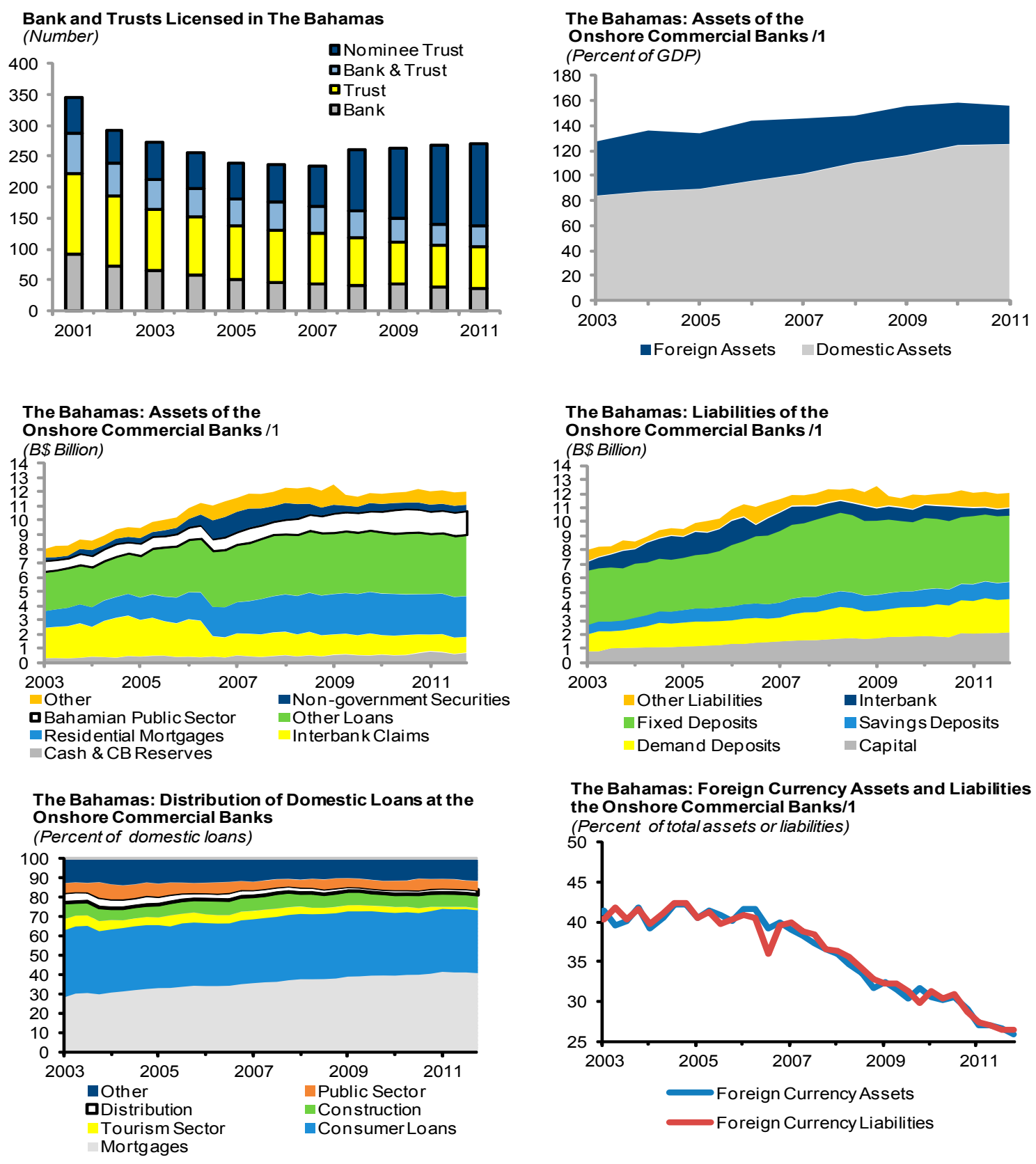

Sources: Central Bank of The Bahamas; IMF staff calculations.

1/Excludes the Bahamian subsidiary of a North American bank registered as an onshore commercial bank because of the subsidiary's specific business model and its large holdings of foreign assets that are funded with foreign liabilities. The subsidiary's domestic assets are relatively small. 
19. There are $\mathbf{1 0}$ other local financial institutions focused primarily on wealth management services to residents and non-residents. These institutions hold $\mathrm{B} \$ 2.9$ billion in assets, 97 percent of which are offshore. Most of the issuers on the stock exchange, the Bahamas International Securities Exchange (BISX), are financial institutions. ${ }^{10}$ Stocks are bought primarily by buy-and-hold investors, with the BISX averaging only two trades per day.

20. There is a small credit union sector with $\mathbf{1 0}$ institutions, $\mathbf{B} \$ \mathbf{2 7 2}$ million in assets and 27,700 members at end-2011. The sector is highly concentrated, with the largest institution accounting for 52 percent of total assets. The Bahamas Cooperative League acts as the credit unions' umbrella association and provides central services to its members. Supervision is by the Department of Cooperative Development within the Ministry of Agriculture and Marine Resources, but will be moved to the $\mathrm{CBoB}$ after the merger, sale or liquidation of three very small and weaker credit unions with a combined shortfall estimated at about $\mathrm{B} \$ 0.5-1.0$ million.

21. The stock of Bahamian government securities has grown substantially since 2007, reaching 45 percent of GDP in 2011. Onshore commercial banks are the largest holders with 32 percent of outstanding volume at end-2011 (Figure 3). Commercial banks have absorbed 58 percent of net issuance since 2007. Foreign private capital markets absorbed another 39 percent as the government issued two large external U.S. dollar bonds in 2008 and 2009. The government securities market has a fairly evenly distributed maturity profile with an exceptionally long average maturity of around 14 years, thus limiting government rollover risk.

\section{Pensions and insurance}

22. The pension system in the Bahamas consists of a social security benefit, a separate plan for public sector employees, occupational pension plans, and individual retirement plans offered by financial firms. Approximately one fourth of the Bahamian workforce participates in occupational pension plans. The assets managed by these funds grew steadily, exceeding B $\$ 1.1$ billion by 2007 , but fell to under $\mathrm{B} \$ 0.7$ billion by 2011 due to the crisis, mainly because of recaptures by unemployed contributors. Private schemes are managed conservatively, with nearly half their assets in public sector securities and bank deposits. Pending the passage of occupational pension legislation, private pension funds are not currently regulated.

\footnotetext{
${ }^{10}$ Two of the onshore commercial bank subsidiaries of foreign banks have partial listings on the BISX, and all three indigenous banks are also listed.
} 


\section{Figure 3. The Bahamas: Government Securities Investor Base and Maturity Profile}
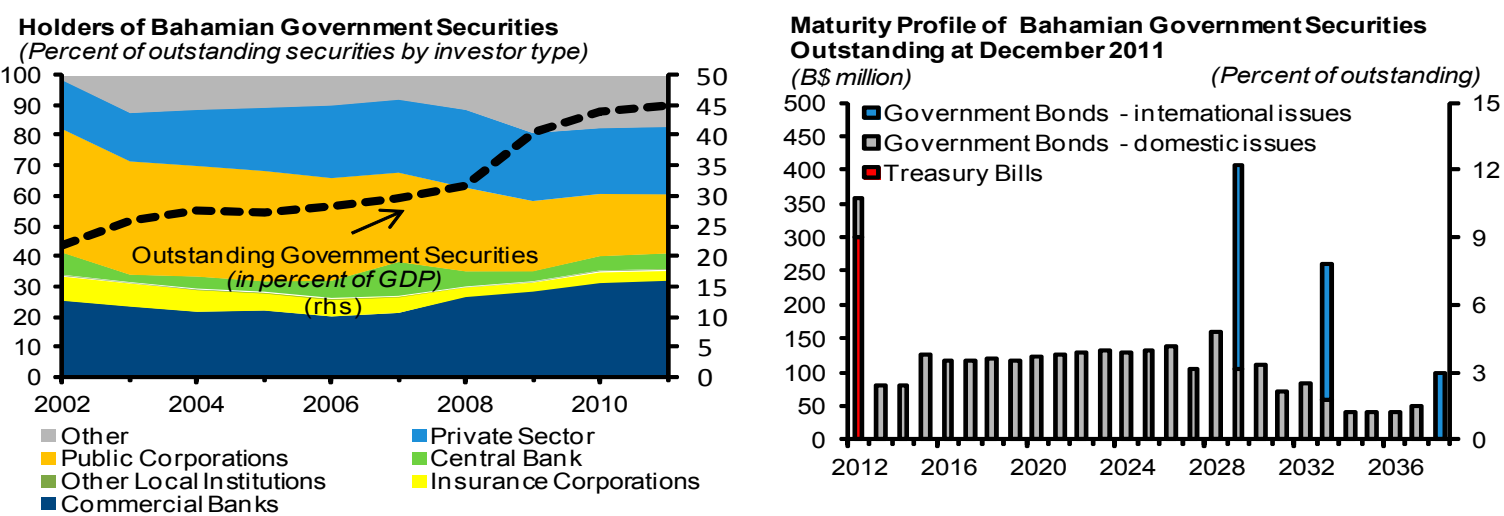

Source: Central Bank of The Bahamas.

23. The insurance sector in The Bahamas, which is primarily domestic, has stagnated, although it has achieved high penetration levels. The sector is dominated by five nonlife insurers and four life insurers writing between eighty to ninety percent of the business. The economic crisis and the low interest rate environment reversed the growth experienced through 2008, with the insurance premium having declined in recent years to around the level of five years ago. With expenditure on insurance already equivalent to over nine percent of GDP, levels characteristic of advanced economies, prospects for further growth are limited. Confidence in the sector has been severely affected by the failure of CLICO (Box 1).

\section{The Bahamas' exposure to hurricanes requires high dependence on}

international reinsurers. The top five nonlife insurers reinsure 60 percent to 80 percent of their risk. More than 90 percent of the reinsurers used are A rated by A.M. Best and belong to the top 25 reinsurers globally. Insurers sell popular long-term products like whole life policies, which have been priced with assumed long-term fixed interest rates of 3 percent to 11 percent that will be difficult to achieve in the current environment, while other savings products include annual return guarantees. Only recently have the products started to be linked to domestic interest rates, implying insurers could be affected by negative spreads.

\section{Investment fund industry}

25. The Bahamas has a large investment fund industry. There are 713 registered or licensed funds, although this has declined from 803 in 2008 due to challenging market conditions and consolidation of some fund operations into foreign jurisdictions (Figure 4). ${ }^{11}$

\footnotetext{
${ }^{11}$ The only category registering an increase in the number of funds was SMART funds, which typically target a small number of investors.
} 
The funds held B $\$ 86.6$ billion of assets under management (AUM) at end-2011, down sharply from $B \$ 298$ billion in 2007 . There are only three fund managers located in The Bahamas, managing twelve funds, with the main business activity in this industry being fund administration.

Figure 4. The Bahamas: Investment Funds Licensed or Registered and Assets Under Management

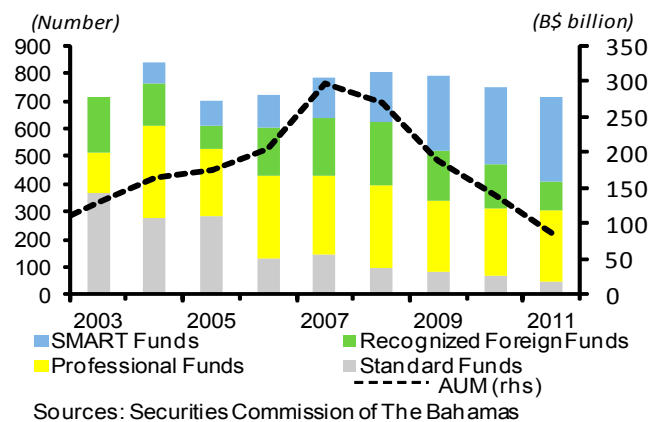

\section{Box 1. CLICO Bahamas Liquidation Update and Recommendations}

CLICO Bahamas Limited (CBL) has been under liquidation since 2009. Actuarial calculations show liabilities of $\mathrm{B} \$ 120$ million with a significant shortfall in the value of the corresponding assets. CBL owns 100 percent of CLICO Enterprises Limited (CEL), a Bahamian-established investment company, and some small non-financial entities. 63 percent of CBL's assets are a B \$73 million loan to CEL. CEL used that money, in turn, to invest in Wellington Preserve Corporation (WPC), a Florida company that held 523 hectares of land in West Palm Beach, of which 238 hectares have been sold, netting B $\$ 10$ million after taxes and fees.

Complex creditors' claims need to be sorted out. Policyholders, banks and two affiliated companies, CLICO Suriname and CLICO Guyana have all filed claims against CBL. In addition, CLICO Trinidad, a Trinidadian insurer fully owned by Colonial Life Financial (CLF) (which is also the ultimate owner of CBL) is alleging a $\mathrm{B} \$ 52$ million claim against CEL and is trying to stop the $\$ 10$ million from going to CBL for the benefit of its policyholders and other creditors. At the same time, CBL holds a guarantee of B $\$ 58$ million for the loan made to CEL from CLF. Discussions are ongoing to offset such guarantee with the $\mathrm{B} \$ 52$ million claim.

The government of The Bahamas has committed to issue a guarantee of $B \$ 30$ million to support policyholders. The government has encouraged policyholders of CBL to maintain their policies in place in the meantime and continue to pay premiums. Currently, $\mathrm{CBL}$ is paying all health insurance related claims and the life claims up to $\mathrm{B} \$ 10$ thousand per policyholder, with any outstanding balance being accrued until the liquidation is finalized.

\section{Concerns and recommendations}

The liquidation of CBL needs to be accelerated. Once the government guarantee is issued, immediate disposal of the life and annuities business should be started to avoid continuing to increase the liabilities as policyholders keep their policies in place due to the seemingly attractive returns. The disposal of the health insurance activity due to its shorter-term character and viability as an ongoing concern should be pursued independently of the life and annuities business. CBL, although still acting as an insurer, needs to update financial statements, which have not been issued since 2009 . 


\section{Offshore financial sector}

26. The Bahamas is host to large global international financial institutions. There are 98 banks and trust companies operating under public licenses in the offshore sector, including 24 euro-currency branches of foreign banks and trust companies and 74 Bahamian incorporated subsidiaries (out of which 56 are foreign-owned). Aggregate assets in the offshore banks amounted to US\$583 billion at end-2011.

27. The business models of large international banks are diverse. Wholesale banking accounts for some 80 percent of assets of the total system. The largest entities act as a booking center for intra-group funding operations, and do not receive deposits or other funding from external third-parties. ${ }^{12}$ Some offshore banks offer overnight sweep accounts for a diversified customer pool outside of The Bahamas. A significant private banking/wealth management industry caters to sophisticated high and ultra-high net worth individuals domiciled globally, and its revenues stem from fee-based income, with the risks of asset deterioration borne by clients rather than by the financial institutions. Finally, some offshore banks undertake investment banking activity, assisting foreign affiliates of the parent company's customers to raise working capital, often acting as a booking center for Latin American offshore business operations. The offshore sector is highly concentrated and branches account for the lion's share of its assets (Table 5). Nine branches of global banks headquartered in Europe, the United States, and Brazil collectively account for over 90 percent of the offshore sector. These do not operate under the host country's regulations on capital, since there is no required delegated capital situated in the branches.

\section{Table 5. The Bahamas: Largest Offshore Entities (In US\$ million)}

\begin{tabular}{llr}
\hline Type & Business Model & Assets, March 2012 \\
\hline Branch & Wholesale Banking & 282,002 \\
Branch & Wholesale Banking & 85,015 \\
Branch & Investment Banking & 43,239 \\
Branch & Private Banking/Wealth Management & 29,527 \\
Branch & Investment Banking & 13,256 \\
& & 453,039 \\
Top five entities & & 504,821 \\
Largest fifteen entities & & \\
\hline
\end{tabular}

Source: CBoB and IMF Staff estimates.

28. Offshore banks are primarily funded by intragroup cross-border funding, as well as non-resident deposits (Figure 5). The former is due to some large international

\footnotetext{
${ }^{12}$ Liquidity management is centralized at the regional/global level and managed from outside the jurisdiction.
} 
banks operating a central treasury model, that is, the parent located in one jurisdiction grants its branches and subsidiaries in third jurisdictions access to the parent's global pool of liquidity via The Bahamas. Such operations are located in The Bahamas for a variety of reasons, including local expertise, administrative ease, exchange control in the home jurisdiction, and in some cases, tax advantages. ${ }^{13}$

\section{Figure 5. The Bahamas: Liabilities of the Offshore Banks}

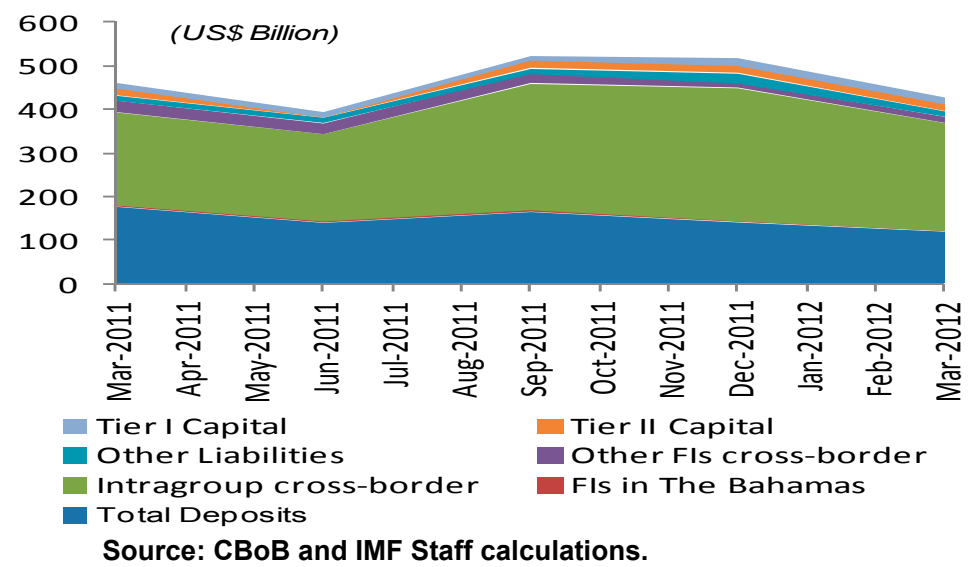

29. Despite sustained challenges to global banking from the financial crisis, offshore banking in The Bahamas proved resilient. A 15.1 percent contraction in balance sheets and a 10 percent decline in fiduciary assets in 2009 were due to lower market valuations and the sale of business lines as part of broader balance sheet deleveraging by global parents, but the trend was reversed as total assets picked up by 12.6 percent in 2011. The views expressed by the industry for its prospects are mixed. While heightened regulatory uncertainty due to ongoing global initiatives may lead to outflows from international financial centers, concerns over tax hikes on wealthy investors in other jurisdictions and heightened political risk in Europe could increase the attractiveness of The Bahamas as a global hub for international financial services.

\section{Liquidity Management}

30. Despite commercial banks' holdings of substantial amounts of excess liquidity, the interbank market is inactive. The lack of high yielding domestic instruments and strict controls on foreign currency net open positions limit banks' ability to take risky positions, leading them primarily to park excess liquidity in non-remunerated deposits at the $\mathrm{CBoB}$.

\footnotetext{
${ }^{13}$ Such tax advantages do not apply for institutions whose parents are in jurisdictions that apply taxes on a consolidated global basis.
} 
Banks have stopped actively bidding for fixed term deposits, and the consequent softening in deposit rates has led to a widening of interest margins since 2010.

\section{Lower deposit rates have not fed into inflation amid subdued economic} conditions and given the U.S. dollar peg. Given the current depressed state of demand, an autonomous surge in imports (as opposed to a pickup related to inward investment flows) appears unlikely. The CBoB monitors monthly how excess reserves may affect banks' behavior and feed into macroeconomic aggregates. Nonetheless, the CBoB should step up efforts to forecast developments in excess reserves to prepare for a future period in which such reserves could translate into import surges, necessitating pre-emptive corrective action.

\section{The ONShORE FinANCIAL SECTOR - Risks AND RESILIENCE}

\section{A. Banking Sector}

32. The Bahamian onshore banking system is profitable, has an extremely strong and high-quality capital base and high liquidity, and virtually no exposure to crossborder funding or FX risk. (Appendix Table 8) ${ }^{14}$ Commercial banks are subject to a target capital adequacy ratio (CAR) of 17 percent and a trigger CAR of 14 percent, much higher than international norms. Failure to meet the thresholds triggers supervisory intervention. ${ }^{15}$ At end-2011, the actual aggregate CAR was at about 28 percent, well above the CBoB's required ratios, with Tier 1 capitalization at 25 percent. ${ }^{16}$ All banks reported CARs above the regulatory target of 17 percent at end-2011. Banks are somewhat heterogeneous though with one commercial bank's CAR around 50 percent, while most were clustered around 20 percent (Figure 6). The ratio of liquid assets to total assets was around 20 percent at end2011.

33. Banks remain profitable, although profitability has moderated, mainly due to increased provisioning expenses that have doubled since 2008 (Figure 7). Banks benefit from high net interest income that remained steady at around $51 / 2$ percent during 2007-11 despite the recession, and return on assets (ROA) is at the top of the range of Caribbean peers. Return on equity (ROE), at 17 percent since mid-2007, is more in line with Caribbean peers and broader international norms due to the high level of capital (Figure 8).

\footnotetext{
${ }^{14}$ A lack of bank specific balance sheet data prevents the computation of FSIs on offshore banks.

${ }^{15}$ A breach of the 17 percent target ratio results in discussions with the $\mathrm{CBoB}$ to develop a plan to restore capital, while a breach of the 14 percent trigger ratio would result in the $\mathrm{CBoB}$ taking enforcement actions on the bank to restrict lending/asset growth until capital is restored.

${ }^{16}$ A couple of banks have some preference share capital but the CBoB has instructed them to phase this out in anticipation of the adoption of Basel III.
} 
Figure 6. The Bahamas: Performance of Onshore Commercial Banks

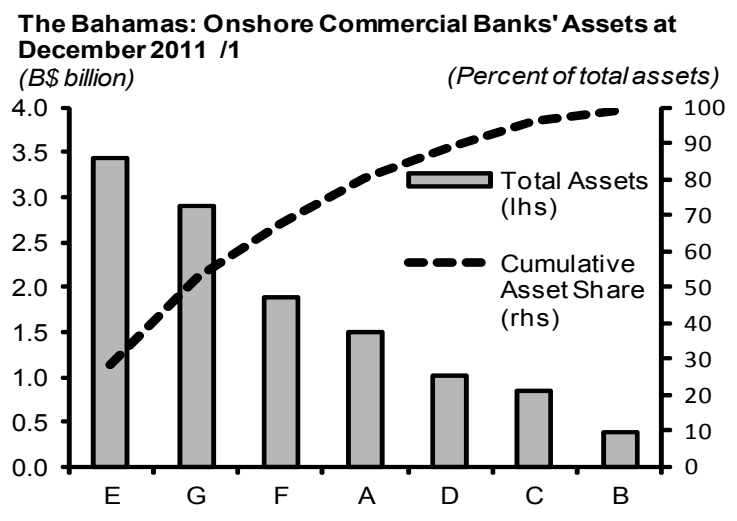

The Bahamas: Onshore Commercial Banks' Assets at December $2011 / 1$

(Percent of resident loans)

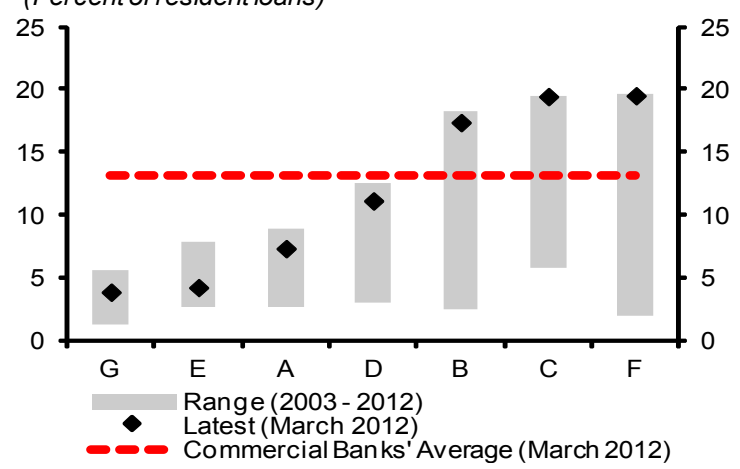

The Bahamas: Onshore Commercial Banks' Assets Return on Assets /1

(Percent of average assets)

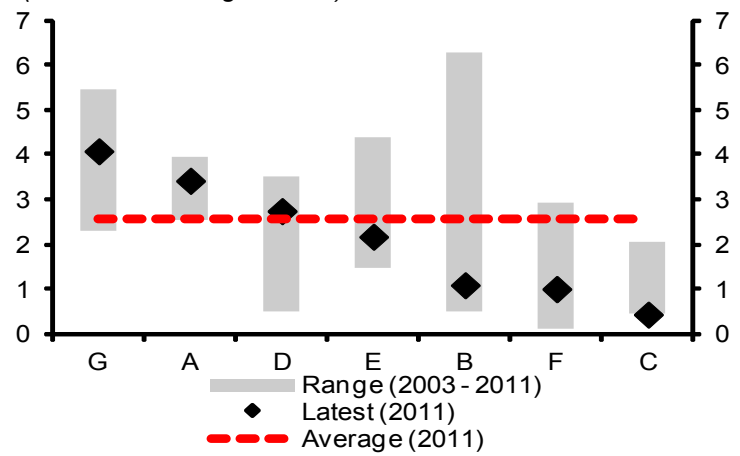

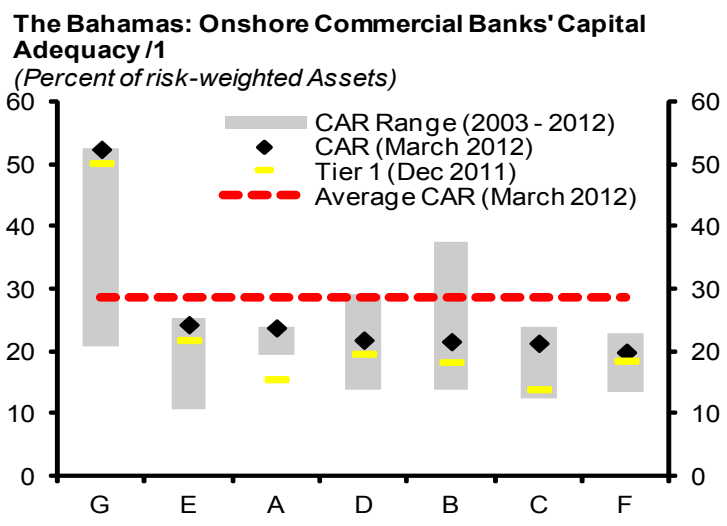

The Bahamas: Onshore Commercial Banks' Provisionsto-NPLs /1

(Percent of NPLS)

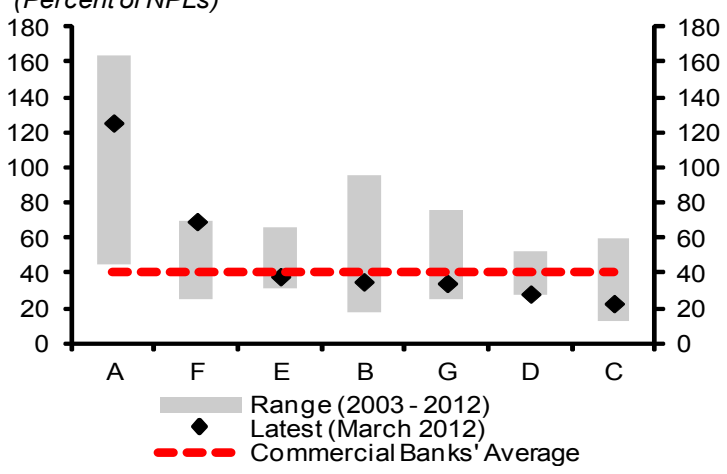

The Bahamas: Onshore Commercial Banks' Return on Equity /1

(Percent of average assets)

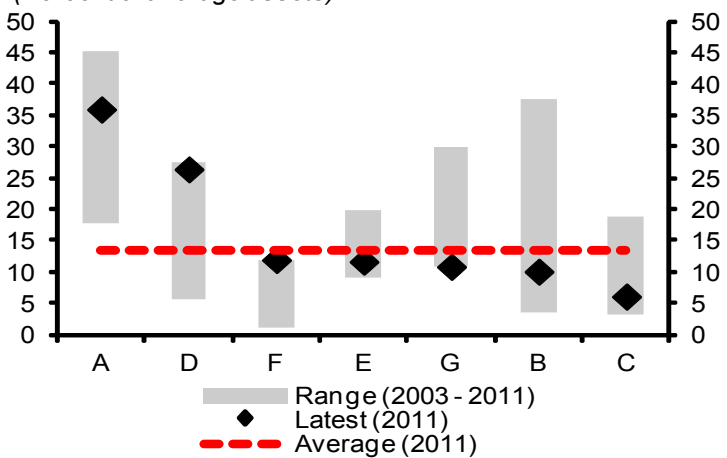

Source: Central Bank of The Bahamas; IMF staff calculations.

1/Excludes the Bahamian subsidiary of a North American bank registered as an onshore commercial bank because of the subsidiary's specific business model and its large holdings of foreign assets that are funded with foreign liabilities. The subsidiary's domestic assets are relatively small. 


\section{Figure 7. The Bahamas: Performance and Soundness Indicators of Commercial Banks}
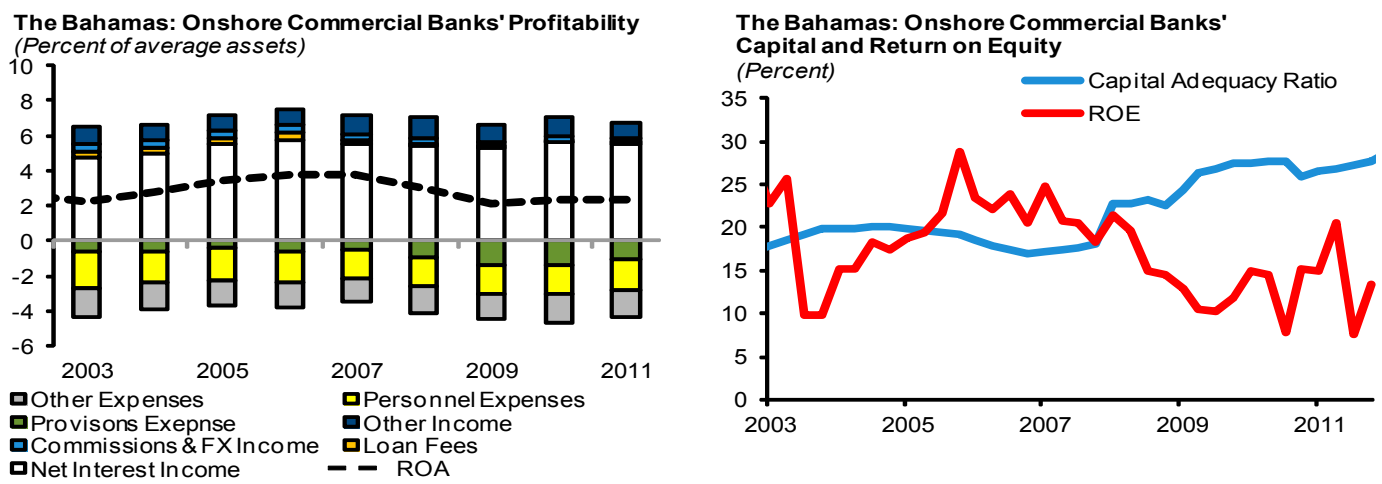

The Bahamas: Onshore Commercial Banks

NPL Rates by Loan Type

(Percent of outstanding loans)
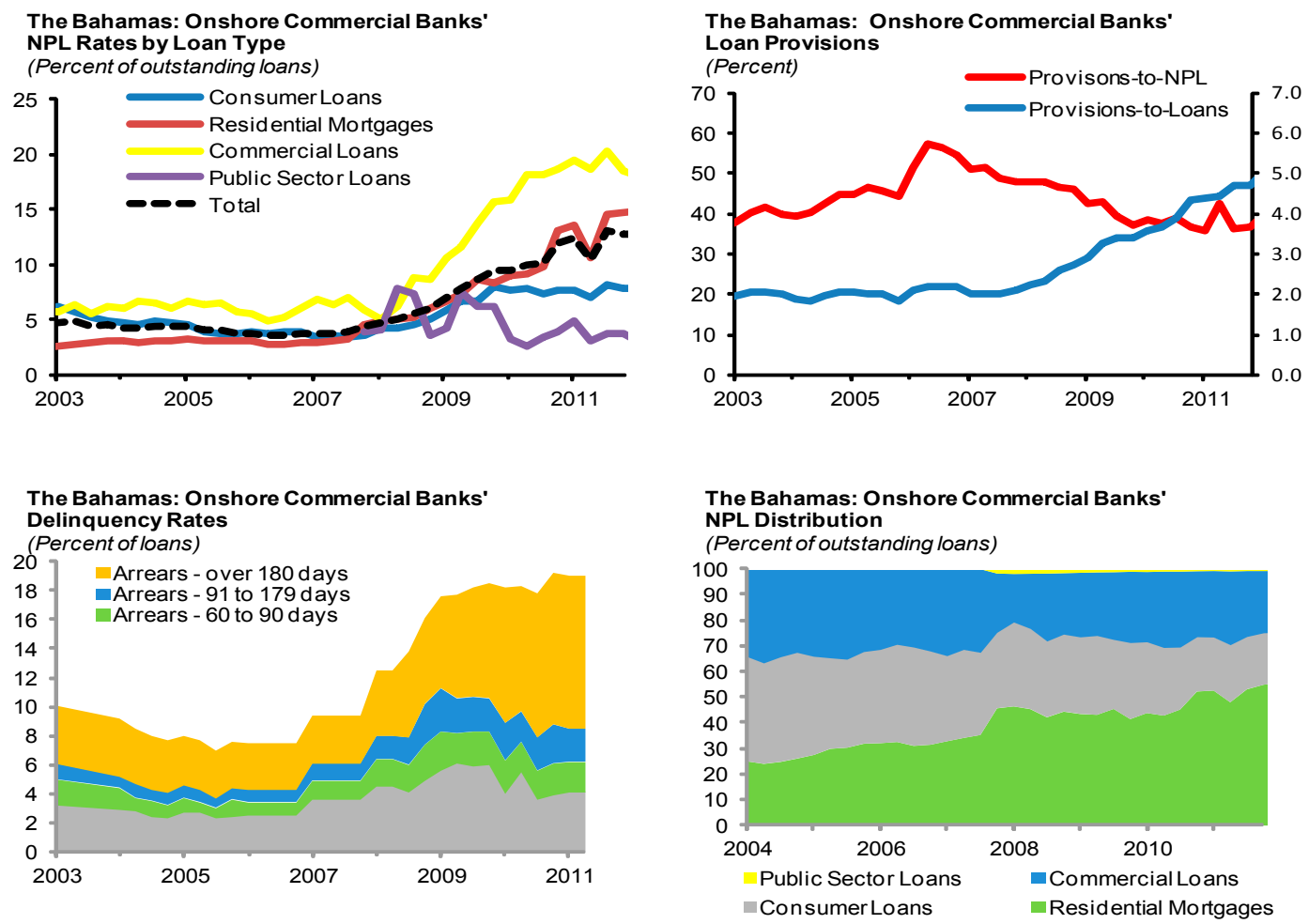

Sources: Central Bank of The Bahamas; IMF staff calculations. 
Figure 8. The Bahamas: Selected Peer Countries: Capital and Return

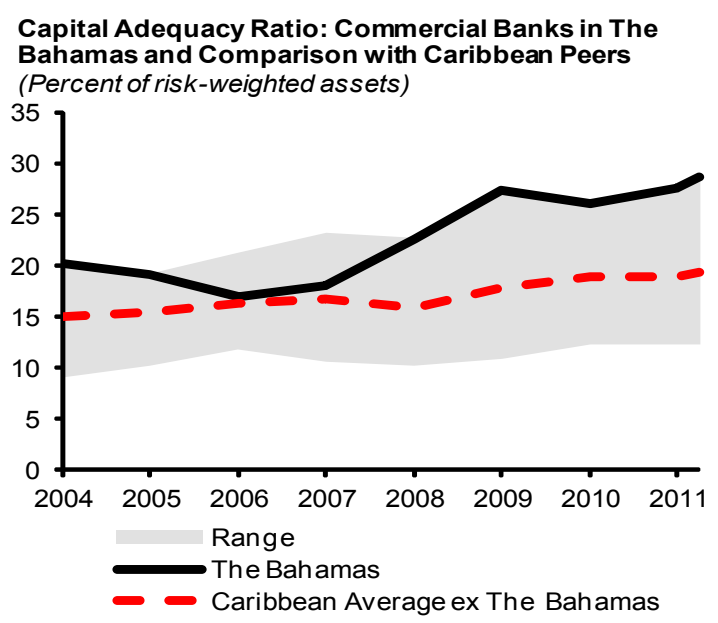

Return on Assets: Commercial Banks in The Bahamas and Comparison with Caribbean Peers

(Percent of NPLs)

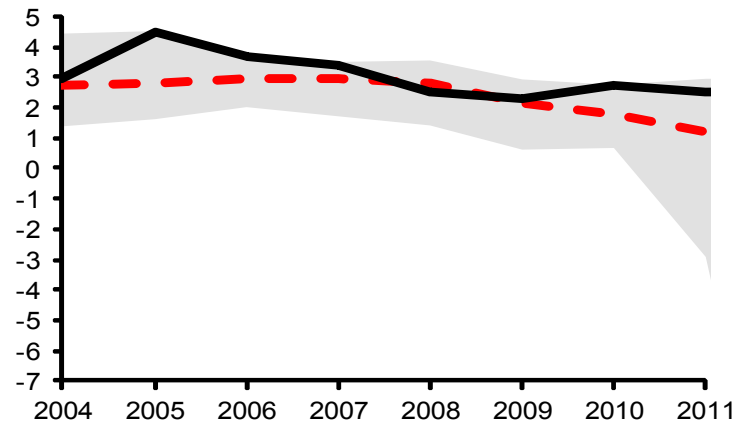

Return on Equity: Commercial Banks in The Bahamas and Comparison with Caribbean Peers

(Percent of NPLs)

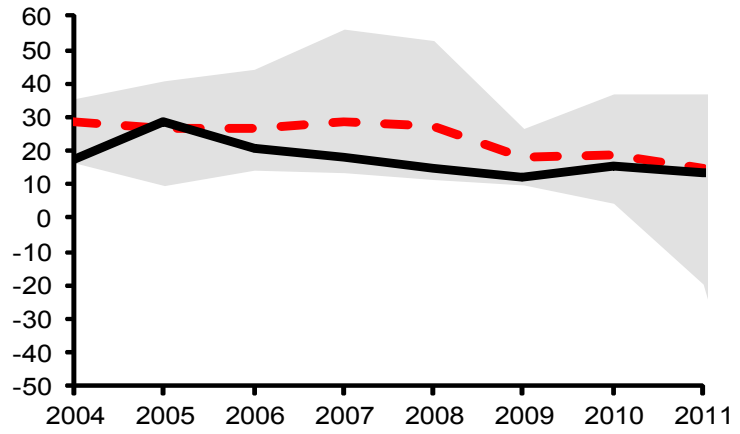

Capital Adequacy Ratios in March 2012: Commercial Banks in The Bahamas and International Peers

(Total regulatory capital to risk-weighted assets, in percent)

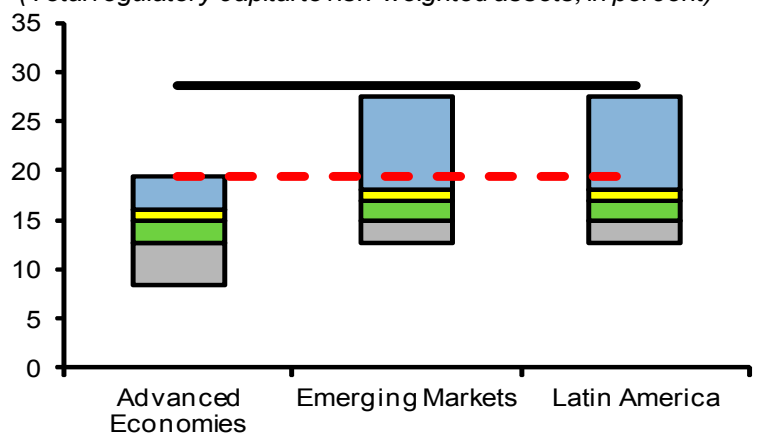

Quantiles for FSI-reporting countries:

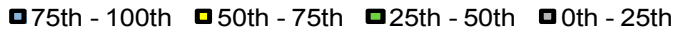

$$
\text { The Bahamas - - - Caribbean }
$$$$
\text { ex The Bahamas }
$$

Return on Assets in 2011: Commercial Banks in The Bahamas and International Peers

(Percent)

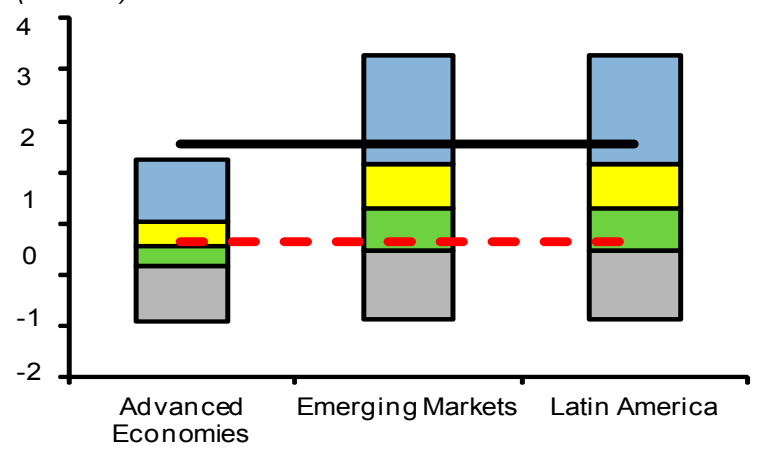

Return on Equity in 2011: Commercial Banks in The Bahamas and International Peers

(Percent)

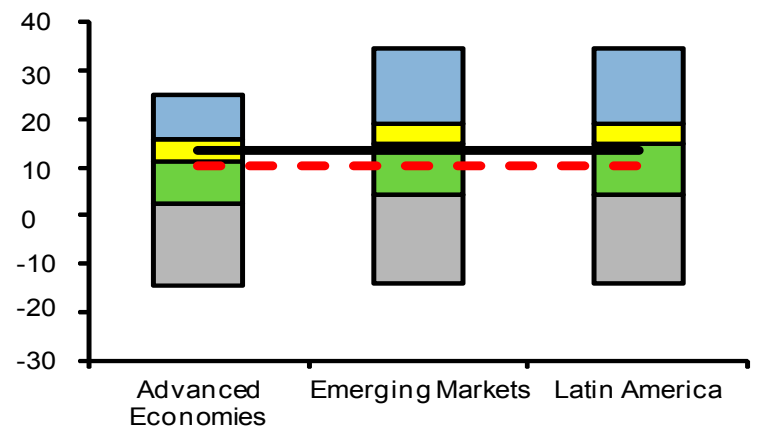

Sources: Country authorities; IMF; IMF staff estimates .

Notes: Data for The Bahamas at March 2012; data for other Caribbean countries at December 2011, except for Belize and Guyana at March 2012; Caribbean peers are Barbados, Belize, Guyana, Jamaica, Suriname, and Trinidad and Tobago; quantiles shown are for FSI-reporting countries based on latest available FSI data; The Bahamas is not an FSI-reporting country and is not included in the quantiles for the FSI-reporting countries. 


\section{A sharp rise in NPLs is concentrated in mortgages ( 55 percent) and commercial} loans (24 percent). The severe decline in tourism due to the U.S. recession led to a rise in the NPL ratio from 3.8 percent in June 2007 to 12.8 percent in March 2012, higher than the Caribbean regional average (Figure 9). Loan quality appears to have been stabilizing since mid-2011 as tourism activity has picked up and large FDI projects have resumed. Nonetheless, delinquencies remain high at 19 percent of total loans and delinquencies greater than 180 days have increased, indicating deterioration within NPLs.

35. High NPL rates on mortgages (14.9 percent at March 2012) partly reflect bank's reluctance to foreclose on properties as house recovery values are low. By contrast, bank NPL rates on consumer loans (which are often unsecured) are only 7.8 percent since banks write these off after they are delinquent for 180 days. Commercial loans have the highest NPL ratio at 18 percent. Differing asset mixes help explain the significant variation of NPLs across banks, which range from 4.3 percent to 17.7 percent, with banks that have a larger share of mortgages reporting higher NPLs. Provisioning rates similarly vary from 23 percent to 126 percent with higher rates for those banks that have a higher share of consumer loans.

36. High NPLs do not pose an immediate threat to banks. The $\mathrm{CBoB}$ meets regularly with the banks and closely monitors the evolution of problem loans and collateral. It has pushed banks to be more aggressive in their collateral valuation practices, including accounting for the time cost of recovery. It also may require independent credit and collateral valuations for problem mortgages, based on onsite examination reviews, and especially where provisions do not appear to be realistic. Moreover, although mortgage collateral values are estimated to have fallen 20-30 percent, stress tests applied conservative haircuts of up to 60 percent and worst-case scenarios assume no offset from collateral. The tests indicate that banks' very high capital ratios represent a significant buffer, although extreme credit shocks would pose challenges for those banks with weaker capital positions. There is some degree of uncertainty on the overall evolution of house prices since reliable indices are not available and there are relatively few transactions on which to base firm judgments. Hence, monitoring would be enhanced by the development of real estate price indices.

\section{Stress tests}

\section{The resilience of seven of the eight onshore commercial banks was assessed} through top-down (TD) and bottom-up (BU) stress tests (see Box 2 for details). ${ }^{17}$ Both sets of tests assessed banks' solvency and liquidity risks using end-2011 data and resulted in similar findings. Stress tests were not conducted on the offshore banking system due to a lack of bank-specific balance sheet data.

\footnotetext{
${ }^{17}$ One of the onshore commercial banks is a foreign branch that operates mainly offshore and was excluded from participation in the exercise because as a branch, it has no required delegated capital.
} 
Figure 9: The Bahamas: Selected Peers: NPLs and Provisions
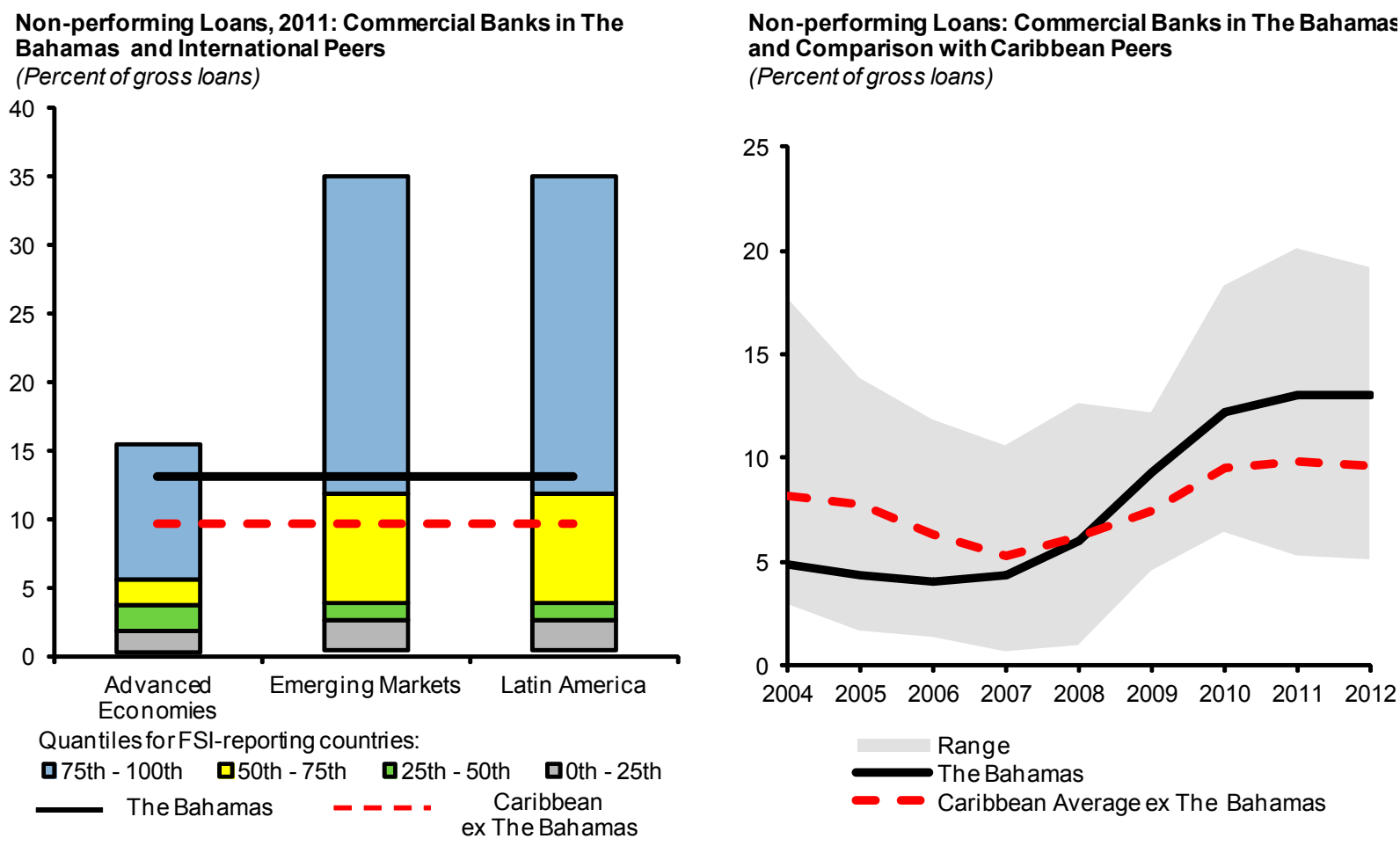

Loan Provisions: Commercial Banks in The Bahamas and Comparison with Caribbean Peers

(Percent of gross loans)

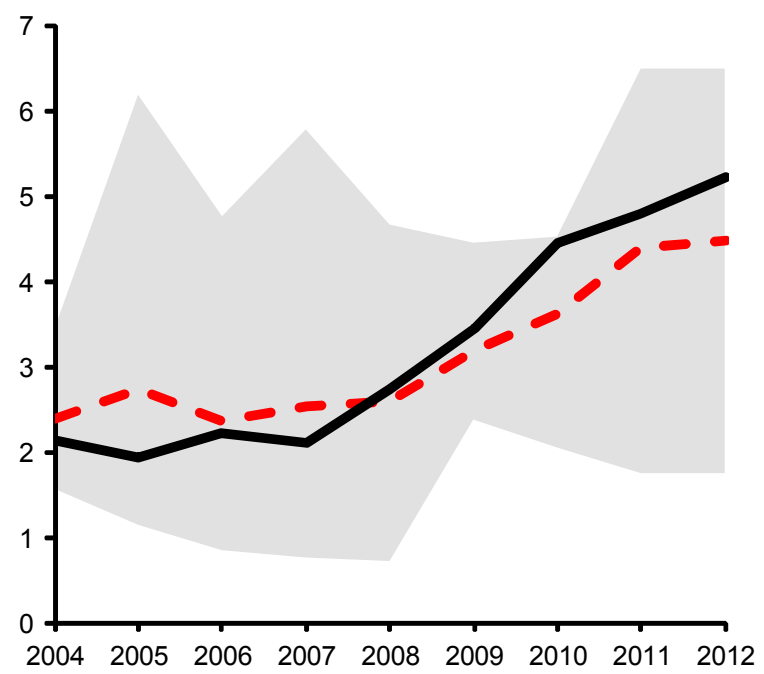

Loan Provisions to NPLs: Commercial Banks in The Bahamas and Comparison with Caribbean Peers (Percent of NPLs)

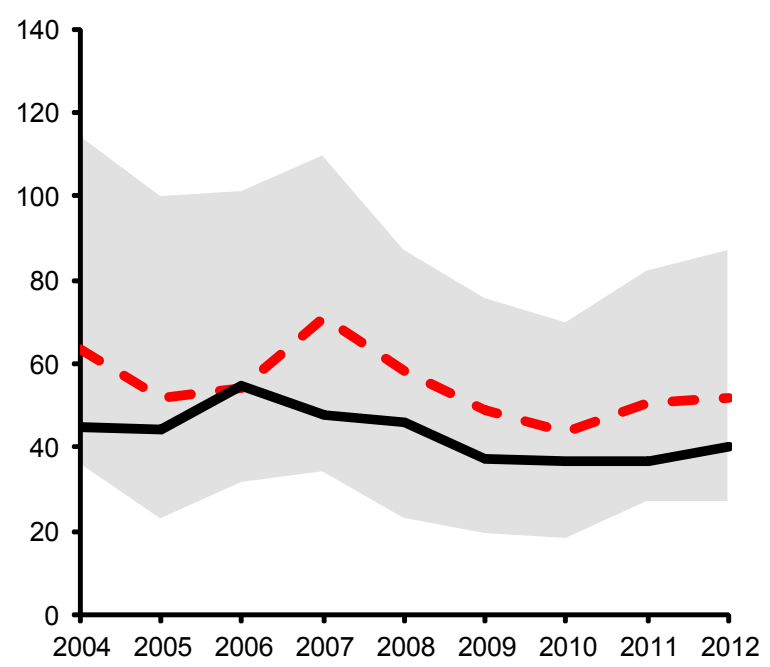

Sources: Country authorities; IMF; IMF staff estimates .

Notes: Data for The Bahamas at March 2012; data for other Caribbean countries at December 2011, except for Belize an Guyana at March 2012; Caribbean peers are Barbados, Belize, Guyana, Jamaica, Suriname, and Trinidad and Tobago; quantiles shown are for FSI-reporting countries based on latest available FSI data; The Bahamas is not an FSI-reporting country and is not included in the quantiles for the FSI-reporting countries. 


\section{Box 2. Stress Test Scenarios and Methodologies}

The solvency tests covered credit risk, credit concentration risk and market risk. Single factor tests based on a balance sheet approach measured the impact of a deterioration of loan quality, sectoral concentrations, a default of large borrowers, and shifts in the yield curves in domestic and foreign currency. Behavioral and regulatory responses were modeled through payout ratios and loan restructurings. Banks were allowed in some of the tests to use collateral, after conservative haircuts, to offset losses. ${ }^{1}$

Macro stress tests assessed potential short- and medium-term risks from five scenarios: (i) a baseline scenario based on the April 2012 IMF World Economic Outlook (Scenario 1); (ii) a global recession, which would have spillover effects to The Bahamas through a slowdown in tourism receipts (Scenario 2); (iii) a substantial and prolonged increase in oil prices due to a supply shock, which leads to a slowdown in tourism receipts and an independent effect on NPLs through a decline in disposable income (Scenario 3); (iv) a slowdown in FDI flows (Scenario 4); and (v) a large-scale hurricane which would cause a disruption in tourist arrivals (Scenario 5).

The macro scenarios were calibrated using econometric and statistical methods. The impact of tourism receipts, oil prices and FDI flows on GDP growth was based on the CBoB macro model, whereas the impact of the hurricane scenario on tourism and GDP growth was calibrated on historical data. The macro-financial projections were derived from IMF staff regression estimates that link bank-level NPLs to lagged GDP growth, the real T-bill rate, and the oil price index. The macro shocks were assumed to occur in the second half of 2012 and their impact to gradually decrease over the next several years. Each scenario simulated light, medium and severe shocks, roughly corresponding to one, one and a half and two standard deviations from the baseline, which resulted in different trajectories for banks' NPLs and CARs (Figure 10).

${ }^{1}$ Collateral was considered in the credit risk stress tests that focused on the entire credit portfolio. However, a breakdown of collateral by loan classification categories and sectoral exposures was not available and so the stress tests on loan migrations and sectoral credit risk abstracted from collateral effects. The large exposures credit risk stress tests also took a more conservative approach and abstracted from collateral coverage. When collateral was considered in the bottoms-up large exposures credit risk tests, the impact on capital was minimal since the collateral provided adequate coverage.

38. Solvency stress tests suggest that the banking system as a whole is in a position to withstand a range of adverse scenarios. Of five scenarios tested, the one involving a combined shock to tourism revenues and oil prices would have the most severe impact. This would lead in the worst-case outcome to an increase in already high NPLs of almost 100 percent, but even under this scenario, the system's CAR would remain above the regulatory trigger of 14 percent. ${ }^{18}$ Nevertheless, there are pockets of vulnerabilities and some banks with higher NPLs and lower capital, including a large bank, would breach the regulatory 14-percent benchmark. ${ }^{19}$ The risks from a large-scale hurricane appear

\footnotetext{
${ }^{18}$ In the worst-case scenario aggregate NPLs reach 25 percent of total loans and represent a substantial drag on profits through reduced net interest income and increased provisions. Therefore, this scenario has a considerable impact on banks' capital.

${ }^{19}$ The systemic potential of individual bank problems is contained by the low level of interbank exposures.
} 
significantly mitigated by the practice of relying on reinsurance proceeds to quickly rebuild damaged infrastructure.

\section{Figure 10. The Bahamas: Macro Stress Test Outcomes}

(In percent)
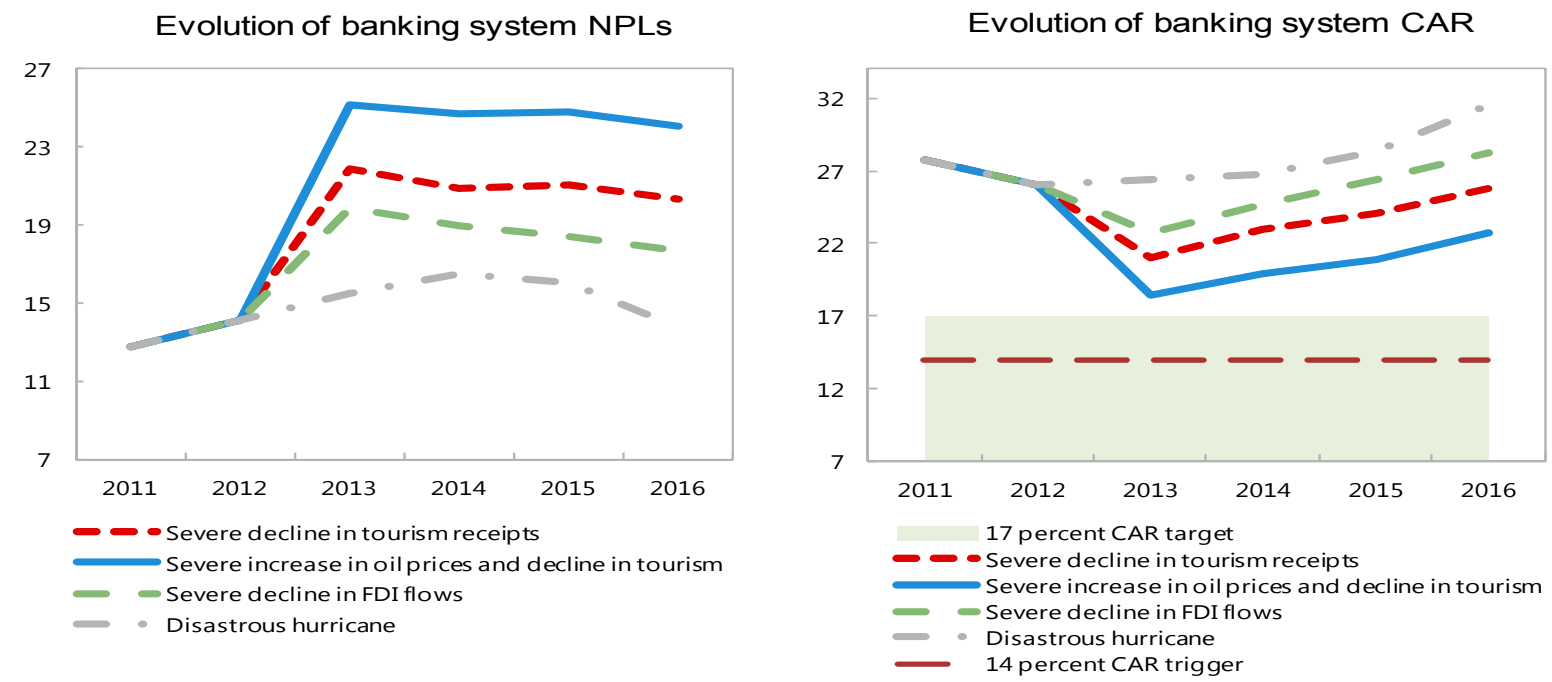

Number of banks below the 17 percent CAR target

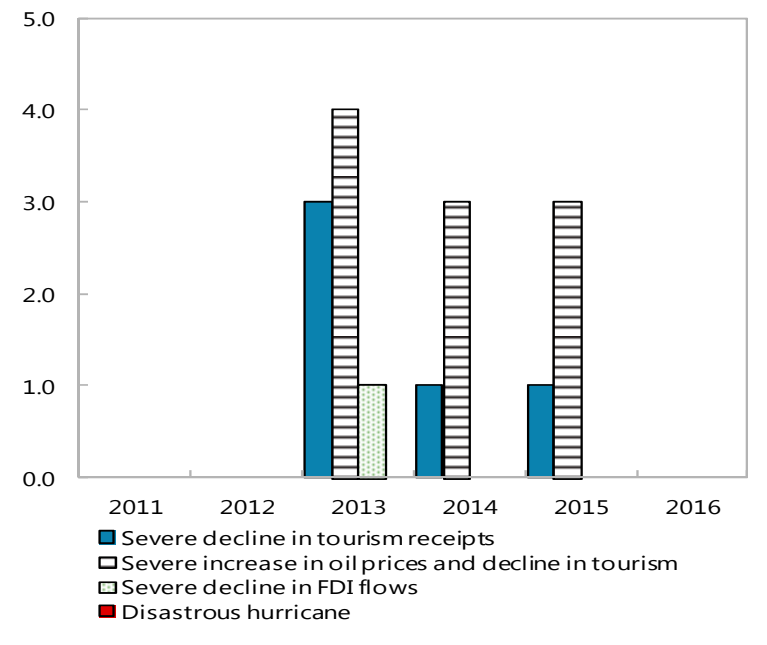

Capitalization needs to meet the 17-percent CAR target

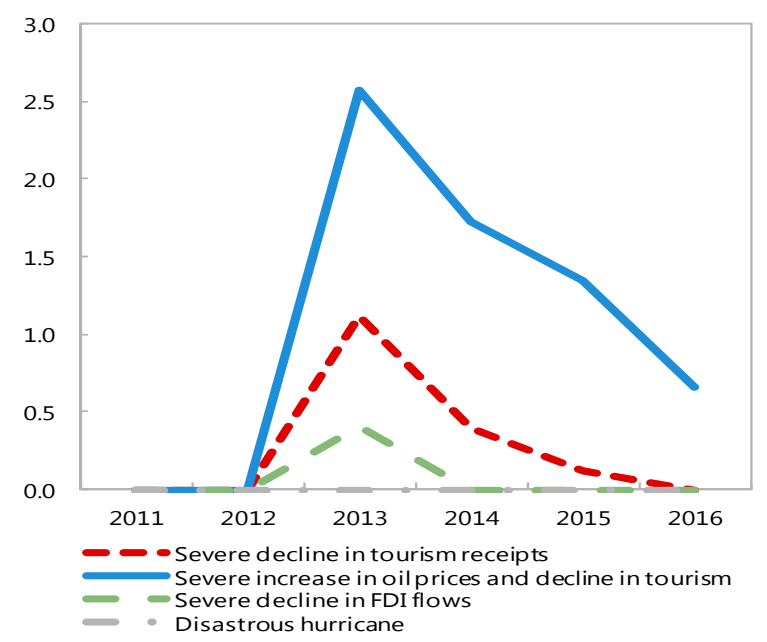

Source: National authorities and IMF staff estimates. 
39. Sensitivity analysis revealed credit risk as a key source of risk for the banking system. The analysis modeled the impact of NPL increases of up to 300 percent on banks' profitability and internal capital generation through reduced net interest income and higher provisioning. The tests adjusted the baseline CAR for a fraction of restructured loans which are likely to return to NPL status. ${ }^{20}$ There is some heterogeneity among banks. While the system's CAR is able to absorb a 100 percent increase in NPLs, this outcome is affected by a large outlier with a CAR of 51 percent. Excluding this bank, the system's post-shock CAR would stand at around 11.5 percent (Table 6) and under more severe shocks would fall below the 8 percent Basel minimum. However, it should be recognized that increases of NPLs of 100 percent or greater are very severe in light of the initial high level.

40. The banking system is fairly robust against concentrations in mortgage lending. At around 15 percent, mortgage NPLs are already high so that, as with NPLs more broadly, a 100 percent increase in NPLs would constitute a significant shock. Mortgage risk stress tests conservatively assumed new NPLs would be 100 percent provisioned and did not take into account offsets from future profits and collateral recoveries. Still, a 100 percent increase in NPLs on mortgage loans pushes only one bank below a 14 percent CAR and none below 8 percent, and leaves the system's CAR at 21 percent, or 16.7 percent excluding the bank with an initial CAR of 51 percent. More severe tests combining shocks to real estate and tourism-related loans (since the quality of these tend to be correlated in economic downturns) would drive around one third of the banks below the 14 percent regulatory trigger ratio, although again, these tests did not take into account collateral coverage.

\section{Market risk is limited, with only modest risk arising from fluctuations in interest} rates. Currency and equity price risks are contained due to banks' limited exposures. Market risks stemming from holdings of government securities are also limited as these are generally held to maturity and both bank loans and government securities are issued mainly at adjustable rates.

\section{Banks' liquidity positions are more sensitive to deposit outflows than wholesale} funding shocks due to their dependence on customer deposits (Table 7). The system could cope with deposit outflows of 5-10 percent of total deposits (although some banks with lower liquidity buffers appear sensitive to shocks to the deposit base), but larger deposit outflows may present some challenges, although such scenarios have a low probability. Nonetheless, banks could tap official liquidity since the $\mathrm{CBoB}$ is committed to redeem all government securities at full value.

\footnotetext{
${ }^{20}$ Haircuts of up to 60 percent were applied on collateral given the degree of uncertainty about housing prices and banks were assumed to retain 50 percent of projected profits. However, a regulatory restriction forbidding any dividend payments was assumed for medium and severe shocks.
} 
Table 6. Summary Stress Test Results: Sensitivity Tests

(In percent, unless indicated otherwise)

\begin{tabular}{|c|c|c|c|c|}
\hline & All banks & All banks 1/ & Domestic & Foreign \\
\hline Reported CAR (December 2011) & 27.7 & 21.9 & 22.4 & 29.5 \\
\hline Adj. CAR & 26.0 & 19.7 & 19.3 & 28.3 \\
\hline \multicolumn{5}{|l|}{ Credit risk } \\
\hline \multicolumn{5}{|l|}{ NPL increase } \\
\hline 100 percent & 16.8 & 11.5 & 13.3 & 18.1 \\
\hline 150 percent & 12.5 & 7.8 & 10.9 & 13.1 \\
\hline 200 percent & 7.2 & 2.9 & 6.8 & 7.3 \\
\hline \multicolumn{5}{|l|}{ Credit downgrades } \\
\hline 30-percent downward Ioan migration & 24.7 & 18.8 & 19.7 & 26.5 \\
\hline 100-percent downgrade of all loans & 18.5 & 12.8 & 14.9 & 19.8 \\
\hline \multicolumn{5}{|l|}{ Credit concentration risk } \\
\hline \multicolumn{5}{|l|}{ Large exposures (without collateral) } \\
\hline Default of the single largest borrower & 21.2 & 14.5 & 18.4 & 22.2 \\
\hline Default of the 3 largest borrowers & 17.8 & 11.7 & 16.9 & 18.1 \\
\hline Default of the 5 largest borrowers & 15.4 & 9.4 & 15.7 & 15.3 \\
\hline \multicolumn{5}{|l|}{100 -percent increase in sectoral NPLs } \\
\hline 5 largest industries & 21.4 & 14.2 & 17.0 & 23.0 \\
\hline Mortgages and tourism-related loans & 22.1 & 15.0 & 18.2 & 23.5 \\
\hline Mortgage loans 2/ & 20.9 & 16.7 & 20.0 & 21.3 \\
\hline \multicolumn{5}{|l|}{ Interest rate risk } \\
\hline \multicolumn{5}{|l|}{ Parallel shifts of the yield curve $3 /$} \\
\hline+200 basis points & 24.3 & 17.7 & 16.9 & 26.9 \\
\hline-200 basis points & 25.9 & 19.7 & 19.3 & 28.2 \\
\hline+400 basis points & 22.3 & 15.1 & 14.0 & 25.2 \\
\hline Steepening of the yield curve & 23.1 & 16.2 & 15.3 & 26.1 \\
\hline Inversion of the yield curve & 26.0 & 19.7 & 19.3 & 28.3 \\
\hline
\end{tabular}

Source: National authorities and IMF staff estimates.

1/ Excluding one bank with a 51 percent CAR.

2/ The stress test conservatively abstracts from future profits and collateral recoveries.

3/ Impact on exposures in domestic and foreign currency. Based on a duration gap analysis that measures the impact on capital. 


\section{Table 7. The Bahamas: Liquidity Stress Test Results (In percent unless indicated otherwise)}

\begin{tabular}{|c|c|c|c|c|c|c|}
\hline & \multicolumn{2}{|c|}{ All banks } & \multicolumn{2}{|c|}{ Domestically-Owned } & \multicolumn{2}{|c|}{ Foreign-Owned } \\
\hline & $\begin{array}{c}\text { Liquid } \\
\text { assets to } \\
\text { total assets }\end{array}$ & $\begin{array}{l}\text { Liquid } \\
\text { assets to } \\
\text { total } \\
\text { deposits }\end{array}$ & $\begin{array}{l}\text { Liquid } \\
\text { assets to } \\
\text { total assets }\end{array}$ & $\begin{array}{l}\text { Liquid } \\
\text { assets to } \\
\text { total } \\
\text { deposits }\end{array}$ & $\begin{array}{l}\text { Liquid } \\
\text { assets to } \\
\text { total assets }\end{array}$ & $\begin{array}{l}\text { Liquid } \\
\text { assets to } \\
\text { total } \\
\text { deposits }\end{array}$ \\
\hline Baseline as of December 2011 & 20.0 & 24.9 & 20.8 & 26.3 & 19.8 & 24.5 \\
\hline \multicolumn{7}{|l|}{ Deposit withdrawals } \\
\hline 5 percent & 16.6 & 20.8 & 17.1 & 21.8 & 16.4 & 20.5 \\
\hline 10 percent & 13.2 & 16.8 & 13.4 & 17.4 & 13.2 & 16.7 \\
\hline 20 percent & 4.7 & 6.1 & 3.9 & 5.3 & 4.9 & 6.4 \\
\hline \multicolumn{7}{|l|}{ Wholesale funding withdrawal } \\
\hline 5 percent & 19.6 & 24.5 & 20.8 & 26.3 & 19.3 & 23.9 \\
\hline 10 percent & 19.3 & 24.1 & 20.7 & 26.2 & 18.8 & 23.4 \\
\hline 20 percent & 18.6 & 23.2 & 20.6 & 26.1 & 17.9 & 22.3 \\
\hline
\end{tabular}

Source: National authorities and IMF staff estimates.

43. Spillover risks are generally insignificant. Domestic bank lending to other onshore financial institutions is negligible. Default risk through interbank exposures is also negligible given very limited interconnectedness within the interbank market. Financial stability concerns from potential financial distress in foreign parent banks appear likely to be muted since international banks transact with overseas counterparties with no material exposure to commercial entities within the jurisdiction and the financial safety net is restricted to the onshore banking sector. In addition, the direct impact of the offshore financial sector on the real economy is limited.

\section{The potential for reputational and other risks stemming from the offshore sector} or a foreign parent falling into difficulties seem to be manageable. Vulnerabilities are mitigated for offshore institutions by the CBoB's supervision of their governance, data retention, and know-your-customer activities. Risks from a foreign parent would appear to be mitigated by the high capitalization of onshore banks. The forthcoming AML/CFT assessment will help the authorities to identify any steps that might be needed to contain domestically-sourced reputational risk stemming from money laundering or terrorism financing activities. 


\section{B. Insurance Sector}

45. Nonlife insurers are managing underwriting risk well. Combined ratios (claims and expenses over premiums) below 100 percent indicate soundness. The ratio of liabilities to equity is low (below two) and solvency ratios are above regulatory requirements. Investments are liquid in accordance with the type of liabilities underwritten by nonlife insurers. Government bonds and cash are the preferred investment instruments with three insurers having over 70 percent of their assets in these classes of investments. Reinsurance is available at a reasonable cost and, as noted, more than 90 percent of the reinsurers used are A-rated by AM-Best and belong to the top 25 reinsurers globally. Reinsurance has proven effective, with quick claims payments made on several occasions, including in 2011 after Hurricane Irene.

46. Asset-liability matching for long-term products needs attention. Liabilities are discounted using the projected performance on the existing investment portfolio for the discount rate. The majority, if not all investment, is local due to exchange control restrictions. Insurers hold high levels of mortgages due to a lack of fixed rate long term local investment instruments. This lack, if combined with a further reduction in interest rates, would create significant strains in the sector. Advances in risk-based supervision should help to capture such vulnerabilities and may lead to requirements for insurers to increase their technical reserves.

\section{Capital Markets}

47. The securities market is small and illiquid. Although most large Bahamian companies are listed, secondary market trading activity is very limited. Institutional investors are faced with a shortage of viable assets for investment other than real estate and Government of The Bahamas bonds. Exchange control provisions have resulted in a stock market that is effectively closed to overseas investors and issuers.

\section{FinANCIAL SECTOR OVERSIGHT AND INFRASTRUCTURE}

48. Since the 2004 OFC assessment, there has been clear and material progress in key areas of financial sector oversight. ${ }^{21}$ Most importantly, the approach to regulation and supervision, including with respect to AML/CFT supervision, has been shifting to risk-based approaches, with some agencies already approaching global best practices.

49. Financial sector supervision is carried out by the three prudential regulators (the CBoB, the SCB, and the ICB). In addition, the Compliance Commission supervises the AML/CFT framework for financial sector businesses that are not subject to prudential supervision. Supervisory coordination is undertaken through the Group of Financial Service

\footnotetext{
${ }^{21}$ Insurance standards were not assessed in the 2004 assessment.
} 
Regulators (GFSR) which includes as members all four supervisors. Representatives of the government attend GFSR meetings. Members are signatories to a Memorandum of Understanding $(\mathrm{MoU})$ allowing information sharing as needed to effectively supervise the financial sector. The MoU outlines the arrangements for consolidated supervision of the single conglomerate/group in The Bahamas, including, but not limited to, regular communication, monitoring of capital and inter-group transactions and to some extent mutual decision-making regarding supervisory approvals and reprimand. The GFSR meets at least on a quarterly basis, but ad-hoc working groups meet more regularly as required.

\section{A. Banking}

\section{Compliance with the Basel Core Principles for Effective Banking Supervision}

(BCP) is good. The $\mathrm{CBoB}$ has made significant enhancements to its supervisory process and regulatory guidance since the 2004 OFC assessment. The blend of onsite, offsite, and quarterly supervisory discussions with the banks that the $\mathrm{CBoB}$ considers as systemic provides coverage of the significant banking risks. Guidelines establish benchmarks for the classification of credits and for specific and general provisions, and the CBoB's assessments of compliance with credit risk management and impaired assets requirements is in compliance with $\mathrm{BCP}$ requirements. ${ }^{22}$

\section{To the extent there are shortcomings, they relate to the need for additional} guidance that is warranted in some risk areas. Draft guidance on interest rate, market, and operational risks should be finalized and implemented. Although the $\mathrm{CBoB}$ performs consolidated supervision based on its broad legal authority, guidance on consolidated supervision would enhance transparency to the market and aid examiners in their work.

52. A risk-based supervisory approach is nearing full implementation. The approach supports the Basel II capital guidelines' Pillar II process. Components of the system include: (i) categorizing banking risks into four categories (business risks, controls, oversight, and governance and financial soundness); (ii) categorizing banks into four impact categories based on size, fiduciary assets, number of employees, and Bahamian dollar deposits; and (iii) risk rating the individual risks of the banks on a scale from one to five. All these elements are analyzed to develop a risk mitigation program for the supervision of each bank. Supporting the offsite supervisory aspect, an electronic reporting system to collect and compute financial indicator ratios has been in place from 2010 . The system is being enhanced to include market risk reporting effective September.

\footnotetext{
${ }^{22}$ The $\mathrm{CBoB}$ requires a one percent general reserve in addition to specific provisions.
} 
53. The CBoB supervises both banks and trust companies, ${ }^{23}$ and onshore and offshore supervision follow the same principles. A number of different banking licenses exist. Distinctions among them relate primarily to the onshore/offshore nature of banking business in The Bahamas, although some types of licenses are legacy related. The CBoB closely supervises both sectors but, consistent with risk-based principles, adjusts the scope of supervision to reflect the risks of each sector and each bank, and their systemic importance. A regime of information sharing, including with foreign supervisors, and regulatory colleges supports $\mathrm{CBoB}$ supervision. ${ }^{24}$

\section{The CBoB has well-trained and dedicated staff in its banking supervision} department. However, it needs to review its staffing complement, with particular emphasis on recruiting specialist staff where it currently lacks in-house expertise.

\section{B. Insurance}

\section{Insurance supervision in The Bahamas has significantly improved in recent} years. New insurance legislation was enacted in 2009 and the ICB was established with a highly qualified staff and the power and independence to properly supervise the industry. The ICB has powers to make rules and to enforce and take regulatory action against insurers and intermediaries for violations of the Insurance Act and regulations. The ICB has already undertaken a major clean up of non-active insurers and a range of other measures that have positively impacted the insurance market, including the introduction of penalties that dramatically lowered overdue premium receivables, financial requirements for insurers, brokers and agents, quarterly supervisory meetings with insurers, and annual stress testing for life insurers. However, there is need for recapitalization of one insurer and the liquidation of CLICO and its sister insurer BAICO should be handled in a manner that maintains as much as possible the credibility of the ICB as the supervisor of market solvency.

56. The ICB has an independent Board. However, the first Board members terms' coincided with each other as well as with the national election schedule, presenting challenges to continuity and possibly to the independence of the Board. A new board was appointed in July 2012.

\section{There is currently sufficient reinsurance capacity and the ICB is strongly} engaged in reinsurance supervision. Solvency oversight reflects appropriate supervisory review of the adequacy and efficiency of insurer risk transfer strategies given the size, nature

\footnotetext{
${ }^{23}$ Trust companies are largely engaged in asset and wealth management activities, although many banks also undertake trust business.

${ }^{24}$ The CBoB participates in a number of regulatory colleges on a regular basis, notably those convened by Canadian authorities. Colleges cover both thematic reviews (including on crisis management principles) as well as reviewing specific financial institutions.
} 
and complexity of the business. It also includes reinsurance considerations in determining capital adequacy. Any shortage of reinsurance capacity could limit the ability of local insurers to provide coverage in the jurisdiction and options to mitigating a shortfall in reinsurance capacity could be given consideration, such as the issuance of catastrophe bonds.

58. Fully implementing a consistent risk-sensitive solvency framework should be a high priority. The current solvency regime uses a simple factor-based test and not risk-based capital. The ICB is aware of the drawbacks of such a simplistic solvency regime and for large insurers, it has required independent actuaries to calculate the minimum capital requirement based on the Canadian solvency regime.

59. Risk-Based Supervision (RBS) is still in its initial stages and essential onsite and offsite supervisory tools need development. The ICB has only recently developed a standardized QRS and is making progress in developing ladders of intervention for progressive escalation of regulatory and remedial intervention. The ICB commenced comprehensive onsite examinations in September 2012. In addition, market conduct enhancements are needed to improve consumer protection.

\section{Capital Markets}

\section{Compliance with the International Organization of Securities Commissions} (IOSCO) Principles is generally high, although some weaknesses need to be resolved. The new SIA has reinforced the supervisory powers of the SCB and secured its independence and the SCB is now better resourced. The SIA also provides an effective framework for the sharing of information and cooperation between the SCB and other regulators, domestic and foreign. Recent amendments to the SIA are intended to enable the SCB to become a full signatory to the IOSCO Multilateral Memorandum of Understanding (MMoU).

61. The SCB is converting its powers into a practical regulatory methodology. The full impact will only become apparent at the end of 2012 and into 2013 as these initiatives are implemented. Compliance and its enforcement will create challenges for the SCB, licensed firms, the corporate sector, and the legal and accounting professions.

62. Supervision consists of a mix of off-site review and on-site inspections, periodic and "for cause." On-site inspections are comprehensive, tailored to match the business models of particular categories of licensees and require the exercise of judgment by examiners. The coverage of some categories of locally domiciled professionals in the investment funds industry (such as fund managers and custodians) is insufficient.

\section{Regulation of the investment funds industry has not kept pace with regulatory}

developments globally. The current governing legislation is a disclosure-based regime and does not provide sufficiently for the SCB to set mandatory asset management standards. Also, the SCB could take a more proactive stance in its due diligence and by expanding the scope of its inspections. 


\section{Pension Funds}

64. Occupational private pension funds are not yet regulated. There is pending high level legislation to regulate the fast growing industry with the main objectives being to reduce abuses, lock-in retirement savings and allow for portability. Occupational pensions will not be mandatory and the legislation does not prescribe the form of pension plans that will be allowed. This is appropriate as it allows for free negotiation between employers and employees.

65. Regulation will be urgently needed for proper implementation of the bill. The bill addresses concentration, liquidity, and liability matching requirements for defined benefit plans. Strict licensing procedures will be of paramount importance to create a sound system.

\section{E. Payments and Securities Settlement Systems}

66. Major reforms started in the early 2000s have placed the Bahamian payment system closer to best international practices. They include among others: (i) the creation of a large-value real-time gross settlement system (RTGS) in 2004; (ii) the establishment of The Bahamas Automated Clearing House (BACH) in 2010 for check and direct credit/debit clearance; (iii) a new Payment Systems Act (PSA) brought into force in 2012 providing the legal basis for the CBoB's oversight of, and the settlement finality in, the payment system; and (iv) the creation of the National Payment Committee, as an advisory body to the $\mathrm{CBoB}$, the composition and responsibility of which is currently under discussion.

\section{Crisis Management and Financial Safety Net}

67. The current framework for financial crisis management and resolution requires strengthening. With the Bahamian financial system suffering only modest and indirect spillovers from the global financial crisis, crisis management, resolution, and safety net frameworks were not tested. The authorities are committed to filling gaps in the framework expeditiously by developing the NFCMP.

68. The $\mathrm{CBoB}$ is the primary financial agency responsible for crisis management and the financial safety net. The financial safety net consists of $\mathrm{CBoB}$ authority to extend emergency liquidity assistance (ELA); a DIC which has authority to provide financial assistance to troubled institutions; and access to the payment system. The DIC's operations are carried out by $\mathrm{CBoB}$ employees via secondment of staff and the provision of administrative services. The CBoB's licensing, supervision, and regulation of financial institutions supports these crisis management and safety net functions, including the role of acting as an early warning system for financial problems. It is planned that supervision of credit unions will be added to the CBoB's duties by the end of the first quarter of 2013.

69. The breadth of the financial safety net is clearly demarcated and covers only the onshore banking sector. The deposit insurance system covers only Bahamian dollar 
deposits in onshore banks. ${ }^{25}$ The lack of deposit insurance coverage for credit unions constitutes a gap in the financial safety net and should be remedied, as intended, after the sector has been cleaned up and come under the supervision of the $\mathrm{CBoB} .{ }^{26}$ The ELA facility is appropriately confined to onshore banks and supervision resources are also properly targeted toward onshore financial institutions through more frequent examinations. If offshore institutions become troubled, $\mathrm{CBoB}$ would work with the home country supervisor to facilitate a resolution, but safety net support would have to be provided by the home country government, although there are as yet no explicit ex ante agreements with foreign supervisors to provide such support. The continued exclusion of the offshore sector from the safety net is appropriate, given its large size relative to the economy's domestic resources and its very limited potential for spillovers to the domestic economy and financial system.

\section{A. Crisis Management}

70. The authorities have committed to implementing an effective crisis management plan. However, there is currently no formalized plan in place that lays out a framework for coordinated decision making and clarifies roles and responsibilities among the MoF, $\mathrm{CBoB}$, DIC, and the non-bank financial supervisors in case of a crisis. The $\mathrm{CBoB}$ has taken the lead in considering the range of topics that must be addressed to make such a plan complete.

71. The development of an NFCMP has commenced. The plan should, as envisaged, create or task a body to facilitate the coordination of action and communication during a crisis. It should define the roles and responsibilities of the main institutions and authorities in the event of a crisis. In addition, the legal framework needs to be reviewed to ensure that the relevant officials have sufficient legal authority to undertake the actions envisaged in the plan. The plan should include an explicit mechanism for financial assistance to troubled institutions beyond current DIC powers, but should make explicit the sequencing of the sources of any capital support, with primacy placed on contributions by the parent company and, in the case of a foreign-owned subsidiary, the home country government. The CBoB should update its 1991 guidelines on the discount window, through which ELA would be provided, to develop procedures specifically to address a system-wide liquidity crisis. ${ }^{27}$ Procedures should also be developed on communications among the authorities in the case of a crisis.

\footnotetext{
${ }^{25}$ Under exchange control regulations, individuals and companies designated resident for exchange control purposes must, with some exceptions, hold their deposits in Bahamian Dollars.

${ }^{26}$ The Credit Union League, which is the Apex body for credit unions, currently administers a stabilization fund for the purpose of protecting credit union depositors. Every credit union contributes to this fund on an annual basis. The Credit Union League also has retained earnings which may be used to cover deposits in the event of a crisis.

${ }^{27}$ Issues to be addressed should include the objective of assistance, eligibility, collateral, interest rates, transparency, and other conditions for assistance.
} 


\section{B. Systemic Risk Management}

\section{A Systemic Risk Surveillance Committee (SRSC) has been constituted to} monitor financial stability of the onshore banking sector and oversee system-wide stress testing. At present, it is self-contained within the $\mathrm{CBoB}$ but a representative of the $\mathrm{MoF}$ should be more directly involved in an observer role on a periodic basis. ${ }^{28}$ The CBoB has begun development of an inaugural financial stability report on systemic risk. The first such report should be issued by the end of the first quarter of 2013.

\section{The CBoB has designated all onshore commercial banks as systemic for the} purpose of supervision, but there also needs to be a more narrowly tailored definition to determine which banks would be eligible for solvency support or other extraordinary intervention. An impact analysis might classify only a small number, if any, of the eight onshore banks as systemic in this latter sense. ${ }^{29}$

\section{The powers to provide financial assistance under law need to be clarified and} appropriately circumscribed. Currently, the legal provision for financial assistance such as solvency support is granted to the DIC, with resources derived primarily from the DIC and the Government, as deemed necessary. However, the DIC does not currently appear to have the financial capacity to provide such financial assistance for medium to large scale single institution resolutions, much less for a systemic crisis, and while it has powers to issue bonds, it is not clear it could do so successfully in a systemic crisis. The ability of the DIC to draw upon government resources should be made both more concrete and appropriately circumscribed. ${ }^{30}$ Consideration should also be given to how the failure of a systemically important financial institution not currently insured under the DIC would be addressed.

\section{Deposit Insurance}

75. A system of deposit insurance has been in existence since 1999. ${ }^{31}$ The level of coverage at $\mathrm{B} \$ 50,000$ is in line with similar jurisdictions and protects approximately

\footnotetext{
${ }^{28}$ The Finance Minister and Governor of the CBoB meet regularly to discuss matters of import, including any crisis management and safety net issues.

${ }^{29}$ In international practice, designation as a systemically important financial institution (SIFI) within a particular financial system indicates that the failure or disruption of the institution could threaten the stability of the financial system. A small subset of institutions is typically designated as SIFIs based on characteristics such as size, interconnectedness, substitutability, or other measurable criteria.

${ }^{30}$ For instance, limitations should be placed on which types of institutions (e.g., the acquiring institution rather than the failing institution) and under which circumstances (e.g., only when an institution is of systemic importance) solvency support would be provided. Additionally, procedures should be developed to address the parameters under which financial assistance would be provided.

31 The system was created after the 1997 failure of Gulf Union Bank, to whose depositors coverage was retroactively applied.
} 
96 percent of depositors by number. The system would benefit from a number of operational changes including to: strengthen transparency and disclosure, undertake a deeper examination of the level of equity capital, reconsider the time allowed for payment of depositors, develop a strategic planning process and identify backup sources of funding (Box 3).

\section{Receivership, Resolution, and Liquidation}

\section{The legal provisions for receivership and resolution would benefit from} consolidation that would give clarity about the boundaries of the specific resolution powers available to the $\mathrm{CBoB}$ and DIC. There are two separate legal frameworks for receivership and resolution of commercial banks operating in the domestic market, one under the BTCRA and one under the Protection of Depositors Act (PDA). ${ }^{32}$ While the risk of overlap is ameliorated by the provision under the PDA that the DIC must comply with the directions of the $\mathrm{CBoB}$ and must act on its advice, the risk of confusion would be minimized by consolidation into a single framework.

77. Additionally, operational procedures should be in place for these functions that goes beyond the general language contained in the statutes. Winding-up procedures are court-based under the Companies Act and not specific to financial institutions.

Administrative procedures specific to the complexities of bank operations should replace those under the Companies Act.

\footnotetext{
${ }^{32}$ Only the $\mathrm{CBoB}$ has power to appoint a receiver or receiver manager of an offshore financial institution.
} 


\section{Box 3. Deposit Insurance Corporation Operational Recommendations}

The operations of the DIC do not currently demonstrate a strong model of transparency and disclosure, shortcomings that the Chairman of the DIC intends to address. The coverage of deposits and the DIC's role in assuring the safety of deposits is not widely known. A public awareness strategy will address this by updating the DIC's website to provide the public with a FAQ tab, relevant laws and regulations, financial audited statements, examples of claims that can be made and payable by the DIC and other related information.

Although the deposit insurance system is structured to operate as an ex-ante or pre-funded system, the DIC seems unlikely to have sufficient equity capital to absorb losses in the case of a significant bank failure. ${ }^{1}$ The required balance of the Fund should be determined through a strategic planning exercise that would analyze the impact of a failure of a singular bank or multiple banks. Following this, the Fund balance should be bolstered through an increase in the annual premium paid by banks.

The allowable period of time for payment of depositors under law in the case of a bank failure is well beyond standard international practice. The DIC has six months to initiate payment of depositors and there is no deadline for completion. If there was a bank failure in the future, the intention of the DIC would be to pay depositors within a month. The recent international trend has been toward reducing this compensation period and a shorter period should be codified in keeping with this trend. ${ }^{2}$

The DIC has been granted operational authority to borrow, but backup sources of funding have not been identified. In the past, the DIC issued five year bonds to fund the payment of depositors. However, in a crisis, this may not be feasible and prearranged access to backup sources of borrowing is desirable, whether from the central bank, MoF or private sources.

${ }^{1}$ An ex ante funding system involves the advance accumulation and maintenance of a fund to cover deposit insurance claims. The fund consists primarily of premiums collected from the members of the deposit insurance system.

2 For the relevant European Union standards on timely payment of depositors see Directive 2009/14/EC of the European Parliament and of the Council of March 11, 2009 amending Directive 94/19/EC on deposit guarantee schemes as regards the coverage level and the payout delay http://eur-

lex.europa.eu/smartapi/cgi/sga doc?smartapi!celexplus!prod!CELEXnumdoc\&lg=EN\&numdoc=32009L0014 
APPENDIX I: The BAHAMAS: RiSK ASSESSMENT MATRIX

\begin{tabular}{|c|c|c|}
\hline $\begin{array}{c}\text { Nature/Source of } \\
\text { Main Threats }\end{array}$ & $\begin{array}{l}\text { Likelihood of Realization of } \\
\text { Threat (in the next two years) }\end{array}$ & $\begin{array}{c}\text { Expected Impact on Financial Stability if } \\
\text { Threat is Realized }\end{array}$ \\
\hline $\begin{array}{l}\text { A severe slowdown of } \\
\text { the tourism industry } \\
\text { as a result of a global } \\
\text { recession that } \\
\text { encompasses the } \\
\text { United States, most } \\
\text { likely triggered by a } \\
\text { further intensification } \\
\text { of the European } \\
\text { crisis. }\end{array}$ & $\begin{array}{l}\text { LOW/MEDIUM } \\
\text { - Current elevated global } \\
\text { economic uncertainty and a } \\
\text { weak labor market and } \\
\text { consumer confidence in the } \\
\text { U.S. exert downward } \\
\text { pressures on The Bahamas } \\
\text { tourism sector. }\end{array}$ & $\begin{array}{l}\text { - The Bahamian economy is heavily } \\
\text { dependent on the tourism industry, which } \\
\text { accounts for about } 50 \text { percent of GDP and } \\
\text { more than half of the total work force. With } \\
\text { the United States accounting for about } \\
80 \text { percent of tourist arrivals, a U.S. } \\
\text { slowdown could have considerable impact } \\
\text { on the domestic economy and onshore } \\
\text { banks' credit quality. } \\
\text { - The experience from the } 2008 \text { global } \\
\text { financial crisis shows that the Bahamian } \\
\text { economy would be hit hard by a slowdown in } \\
\text { the United States. } \\
\text { - While The Bahamas could suffer from } \\
\text { potential repatriation flows to Europe from } \\
\text { OFCs, it is also possible that offshore } \\
\text { centers (particularly those seen as likely to } \\
\text { be more isolated from Eurozone troubles) } \\
\text { could actually benefit from safe haven flows. }\end{array}$ \\
\hline $\begin{array}{l}\text { Substantial and } \\
\text { prolonged increase in } \\
\text { oil prices combined } \\
\text { with a decline in } \\
\text { tourism arrivals due } \\
\text { to geopolitical risks } \\
\text { affecting travel. }\end{array}$ & $\begin{array}{l}\text { LOW } \\
\text { - Geopolitical risks lead ex } \\
\text { ante demand to outpace } \\
\text { supply, exerting upward } \\
\text { pressures on global oil } \\
\text { prices. }\end{array}$ & $\begin{array}{l}\text { MEDIUM/HIGH } \\
\text { - The negative effect on economic growth and } \\
\text { banks' credit quality could be substantial if } \\
\text { the oil price rise occurs in the context of a } \\
\text { supply shock. Higher oil prices could lead to: } \\
\text { (i) higher travel costs, with a direct impact on } \\
\text { the tourism sector; (ii) negative wealth and } \\
\text { consumer confidence effects in the United } \\
\text { States, with a slowdown in tourist arrivals to } \\
\text { The Bahamas; and (iii) given The Bahamas' } \\
\text { high dependence on oil imports, amounting } \\
\text { to } 7.4 \text { percent of GDP, a rise in oil prices } \\
\text { would reduce disposable income and } \\
\text { increase input costs with potential negative } \\
\text { consequences for banks' credit quality. }\end{array}$ \\
\hline $\begin{array}{l}\text { A slowdown in } \\
\text { anticipated FDI } \\
\text { inflows. }\end{array}$ & $\begin{array}{l}\text { LOW/MEDIUM } \\
\text { - An intensification of the crisis } \\
\text { in the Euro area and a } \\
\text { recession in the United } \\
\text { States could lead to a decline }\end{array}$ & $\begin{array}{l}\text { MEDIUM } \\
\text { - A reversal of FDI inflows could negatively } \\
\text { affect economic growth and translate into } \\
\text { higher unemployment and deterioration in }\end{array}$ \\
\hline
\end{tabular}




\begin{tabular}{|c|c|c|}
\hline & $\begin{array}{l}\text { in FDI inflows. } \\
\text { - However, the current small } \\
\text { share of European-sourced } \\
\text { FDI and the large share of } \\
\text { Chinese-sourced FDI related } \\
\text { to the Baha Mar project } \\
\text { should mitigate this risk (but } \\
\text { would make this risk more } \\
\text { likely in response to a } \\
\text { Chinese hard landing). }\end{array}$ & $\begin{array}{l}\text { asset quality (higher NPLs). } \\
\text { Balance of payments impacts would be } \\
\text { significantly offset by the substantial } \\
\text { reduction in FDI-related imports that would } \\
\text { ensue, leading reserves to decline at the } \\
\text { margin. }\end{array}$ \\
\hline $\begin{array}{l}\text { A large-scale } \\
\text { hurricane that } \\
\text { destroys physical } \\
\text { infrastructure, and } \\
\text { which would } \\
\text { significantly reduce } \\
\text { tourism activity. }\end{array}$ & $\begin{array}{l}\text { LOW/MEDIUM } \\
\text { - The Bahamas is vulnerable } \\
\text { to hurricanes. Past } \\
\text { occurrences of hurricanes in } \\
\text { The Bahamas between } 1970 \\
\text { and } 2004 \text { have incurred an } \\
\text { average cost of } 6.5 \text { percent } \\
\text { of GDP, with estimates of the } \\
2004 \text { hurricane as high as } \\
8 \text { percent. }\end{array}$ & $\begin{array}{l}\text { LOW/MEDIUM } \\
\text { - A large-scale hurricane would have a } \\
\text { negative impact on domestic physical } \\
\text { infrastructure and affect GDP growth } \\
\text { through lower tourism proceeds, particularly } \\
\text { if it occurs immediately before the high } \\
\text { season and in combination with an increase } \\
\text { in global risk aversion (a similar scenario } \\
\text { occurred in } 2001 \text { of a combination of } \\
\text { hurricane Michelle and the September } 11 \\
\text { terrorist attack). The impact on economic } \\
\text { growth and NPLs may impair banks' } \\
\text { profitability and capital positions. However, } \\
\text { prompt and widespread reconstruction } \\
\text { activity using reinsurance proceeds is likely } \\
\text { to mitigate these effects. }\end{array}$ \\
\hline
\end{tabular}




\section{APPENDiX II: StRESS TeSTING MATRIX (STEM)}

\section{A. Credit Risk Stress Tests}

\begin{tabular}{|c|c|c|c|}
\hline \multirow{2}{*}{ Scope } & \multicolumn{3}{|c|}{ Assumptions } \\
\hline & BU by banks & TD by CBoB & TD by FSAP team \\
\hline Institutions included & Onshore banks & Onshore banks & Onshore banks \\
\hline Market share & ${\text { Close to } 100 \text { percent }^{1}}^{1}$ & Close to 100 percent & Close to 100 percent \\
\hline Data & Bank own data & Supervisory data & $\begin{array}{l}\text { Supervisory and } \\
\text { public data }\end{array}$ \\
\hline Stress test horizon & 1 and 2 years & 1 and 2 years & 1 and 2 years \\
\hline Shocks/methodology & $\begin{array}{l}\text { A standard template provided } \\
\text { by the FSAP team }\end{array}$ & $\begin{array}{l}\text { Macro stress tests: Slowdown in economic growth against } \\
\text { a baseline from April } 2012 \text { WEO projections. Size of shocks } \\
\text { in line with or larger than the post-crisis contraction of GDP } \\
\text { in } 2009 \text { (roughly } 2 \text { standard deviations from the long-term } \\
\text { average GDP growth). Sizes of GDP shocks are estimated } \\
\text { from various macro shocks, including tourism sector } \\
\text { slowdown, a large hurricane, increase in world oil prices via } \\
\text { CBoB internal sensitivity models. Shocks are translated into } \\
\text { NPLs/PDs via a panel macro-financial model } \\
\text { Single-factor shocks: Asset quality deterioration } \\
\text { (percentage shift from current levels, downward } \\
\text { migrations); reverse stress testing; sectoral shocks (with } \\
\text { attention on real estate); exposure concentration (up to the } \\
\text { five largest borrowers) }\end{array}$ & $\begin{array}{l}\text { Similar to those of the } \\
\text { CBoB }\end{array}$ \\
\hline $\begin{array}{l}\text { Risks/factors } \\
\text { assessed }\end{array}$ & Credit quality deterioration & Credit quality deterioration & $\begin{array}{l}\text { Credit quality } \\
\text { deterioration }\end{array}$ \\
\hline $\begin{array}{l}\text { Calibration of risk } \\
\text { parameters }\end{array}$ & $\begin{array}{l}\text { Actual point-in-time risk } \\
\text { parameters for credit risk } \\
\text { parameters or proxies }\end{array}$ & $\begin{array}{l}\text { Actual point-in-time risk parameters for credit risk } \\
\text { parameters or proxies }\end{array}$ & $\begin{array}{l}\text { Actual point-in-time } \\
\text { risk parameters for } \\
\text { credit risk parameters } \\
\text { or proxies }\end{array}$ \\
\hline $\begin{array}{l}\text { Behavioral } \\
\text { adjustments }\end{array}$ & $\begin{array}{l}\text { Zero payout ratio, collateral } \\
\text { considered only in some tests }\end{array}$ & $\begin{array}{l}\text { Payout ratios and collateral haircuts based on expert } \\
\text { judgment }\end{array}$ & $\begin{array}{l}\text { Similar to those of the } \\
\text { CBoB }\end{array}$ \\
\hline Regulatory standards & Same as for the CBoB & $\begin{array}{l}\text { Basel II/Basel III / Bahamian regulatory CAR thresholds / } \\
\text { Tier } 1 \text { CARs }\end{array}$ & $\begin{array}{l}\text { Same as for the } \\
\text { CBoB }\end{array}$ \\
\hline Results & $\begin{array}{l}\text { CAR/shortfall, system-wide } \\
\text { and by bank } \\
\text { Pass or fail; number of banks } \\
\text { and percentage of assets that } \\
\text { fail } \\
\text { Distribution of capital ratios } \\
\text { across the system by bank } \\
\text { group/type }\end{array}$ & $\begin{array}{l}\text { CAR/shortfall, system-wide and by bank } \\
\text { Pass or fail; number of banks and percentage of assets that } \\
\text { fail } \\
\text { Distribution of capital ratios across the system by bank } \\
\text { group/type }\end{array}$ & $\begin{array}{l}\text { Same as for the } \\
\text { CBoB }\end{array}$ \\
\hline
\end{tabular}

\footnotetext{
${ }^{1}$ The stress tests covered the onshore sector. One bank with small onshore operations is excluded since most of its activity is in the offshore segment, whereas the onshore and offshore activities were reported together in the data.
} 


\section{B. Liquidity Risk Stress Tests}

\begin{tabular}{|c|c|c|c|}
\hline \multirow{2}{*}{ Scope } & \multicolumn{3}{|c|}{ Assumptions } \\
\hline & BU by banks & TD by CBoB & TD by FSAP team \\
\hline $\begin{array}{l}\text { Institutions } \\
\text { included }\end{array}$ & Onshore banks & $\mathrm{N} / \mathrm{A}$ & Onshore banks \\
\hline Market share & Close to 100 percent & & Close to 100 percent \\
\hline Data & Bank own data & & Supervisory and public data \\
\hline $\begin{array}{l}\text { Stress test } \\
\text { horizon }\end{array}$ & $\begin{array}{l}\text { 5-day and 30-day } \\
\text { outflow }\end{array}$ & & 5-day and 30-day outflow \\
\hline Methodology & $\begin{array}{l}\text { Bank-run type tests } \\
\text { (evaluated through } \\
\text { liquidity ratios) }\end{array}$ & & $\begin{array}{l}\text { Bank-run type tests (evaluated } \\
\text { through liquidity ratios) }\end{array}$ \\
\hline Risks & $\begin{array}{l}\text { Bank runs: deposit } \\
\text { withdrawals of up to } 30 \\
\text { percent; wholesale } \\
\text { funding withdrawal of } \\
\text { up to } 30 \text { percent; fire } \\
\text { sales with haircuts of } \\
\text { up to } 40 \text { percent }\end{array}$ & & $\begin{array}{l}\text { Bank runs: deposit withdrawals of } \\
\text { up to } 30 \text { percent; wholesale funding } \\
\text { withdrawal of up to } 30 \text { percent; } \\
\text { fire sales with haircuts of up to } 40 \\
\text { percent }\end{array}$ \\
\hline $\begin{array}{l}\text { Regulatory } \\
\text { standards }\end{array}$ & Liquid asset ratios & & Liquid asset ratios \\
\hline Results & $\begin{array}{l}\text { Liquid asset } \\
\text { ratios/shortfalls } \\
\text { Pass rate }\end{array}$ & & $\begin{array}{l}\text { Liquid asset ratios/shortfalls } \\
\text { Pass rate }\end{array}$ \\
\hline
\end{tabular}




\section{Interest Rate Risk Stress Tests}

\begin{tabular}{|c|c|c|c|}
\hline \multirow{2}{*}{ Scope } & \multicolumn{3}{|c|}{ Assumptions } \\
\hline & BU by banks & TD by CBoB & TD by FSAP team \\
\hline $\begin{array}{l}\text { Institutions } \\
\text { included }\end{array}$ & Onshore banks & Onshore banks & Onshore banks \\
\hline Market share & Close to 100 percent & Close to 100 percent & Close to 100 percent \\
\hline Data & Bank own data & Supervisory data & \\
\hline $\begin{array}{l}\text { Stress test } \\
\text { horizon }\end{array}$ & One year & One year & \\
\hline $\begin{array}{l}\text { Shocks/ } \\
\text { Methodology }\end{array}$ & $\begin{array}{l}\text { An upward and } \\
\text { downward shift in } \\
\text { interest rates (no } \\
\text { active yield curve in } \\
\text { The Bahamas, as most } \\
\text { securities are held to } \\
\text { maturity); impact on } \\
\text { capital adequacy } \\
\text { through profitability }\end{array}$ & $\begin{array}{l}\text { An upward and downward shift in } \\
\text { interest rates (no active yield curve } \\
\text { in The Bahamas, as most securities } \\
\text { are held to maturity); impact on } \\
\text { capital adequacy through profitability }\end{array}$ & $\begin{array}{l}\text { An upward and } \\
\text { downward shift in interest } \\
\text { rates (no active yield } \\
\text { curve in The Bahamas, } \\
\text { as most securities are } \\
\text { held to maturity); impact } \\
\text { on capital adequacy } \\
\text { through capital and } \\
\text { profitability }\end{array}$ \\
\hline Risks & $\begin{array}{l}\text { Only interest rate risks } \\
\text { will be estimated by } \\
\text { banks }\end{array}$ & $\begin{array}{l}\text { Impact of interest rate movements } \\
\text { on capital and profitability }\end{array}$ & \\
\hline Results & $\begin{array}{l}\text { CAR/shortfall, system- } \\
\text { wide and by bank } \\
\text { Pass or fail; number of } \\
\text { banks and percentage } \\
\text { of assets that fail } \\
\text { Distribution of capital } \\
\text { ratios across the } \\
\text { system by bank } \\
\text { group/type }\end{array}$ & $\begin{array}{l}\text { CAR/shortfall, system-wide and by } \\
\text { bank } \\
\text { Pass or fail; number of banks and } \\
\text { percentage of assets that fail } \\
\text { Distribution of capital ratios across } \\
\text { the system by bank group/type }\end{array}$ & Same as for the $\mathrm{CBoB}$ \\
\hline
\end{tabular}




\section{Appendix Table 8. The Bahamas: Selected Economic Indicators}

\begin{tabular}{|c|c|c|c|c|c|c|}
\hline \multicolumn{7}{|c|}{ I. Social Indicators } \\
\hline GDP (US\$ millions), 2011 & 7,788 & & \multicolumn{3}{|c|}{ Poverty rate (percent), 2004} & 9.3 \\
\hline GDP per capita (US\$), 2011 & 22,020 & & \multicolumn{3}{|c|}{ Unemployment rate (percent), 2012} & 14.7 \\
\hline Population (thousands), 2010 & 353.7 & & \multirow{2}{*}{\multicolumn{3}{|c|}{$\begin{array}{l}\text { Population not using an improved water } \\
\text { source (percent), } 2006\end{array}$}} & 30 \\
\hline Life expectancy at birth (years), 2010 & 74.4 & & & & & \\
\hline Adult literacy rate, $15 \&$ up (percent), 2007 & 95.6 & & \multicolumn{3}{|c|}{ Human development index (rank), 2010} & 43 \\
\hline \multicolumn{7}{|c|}{ II. Economic Indicators } \\
\hline & & & & Est. & \multicolumn{2}{|c|}{ Proj. } \\
\hline & & 2010 & 2011 & 2012 & 2013 & 2014 \\
\hline \multicolumn{7}{|c|}{ (Annual percentage changes, unless otherwise indicated) } \\
\hline \multicolumn{7}{|l|}{ Real sector 1/ } \\
\hline Real GDP & & 0.2 & 1.6 & 2.5 & 2.7 & 2.5 \\
\hline Nominal GDP & & 0.7 & 0.2 & 3.2 & 3.5 & 4.4 \\
\hline Consumer price index (annual average) & & 1.3 & 3.2 & 2.3 & 2.0 & 2.0 \\
\hline Consumer price index (end of period) & & 1.5 & 3.2 & 2.3 & 2.0 & 2.0 \\
\hline Unemployment rate (in percent) $2 /$ & & $\ldots$ & 15.9 & 14.7 & $\ldots$ & $\ldots$ \\
\hline \multicolumn{7}{|l|}{ Financial sector } \\
\hline Credit to the nonfinancial public sector & & 37.5 & 4.0 & 9.5 & 9.1 & 8.3 \\
\hline Credit to the private sector & & -0.4 & 1.1 & 0.9 & 2.1 & 3.5 \\
\hline Liabilities to the private sector & & 2.6 & 1.9 & 5.0 & 6.3 & 7.2 \\
\hline \multicolumn{7}{|l|}{ External sector } \\
\hline Exports of goods and services & & 4.4 & 7.6 & 6.6 & 5.8 & 4.0 \\
\hline Of which: Travel receipts (gross) & & 6.6 & 5.0 & 8.1 & 7.2 & 5.0 \\
\hline Imports of goods and services & & 1.1 & 12.9 & 7.3 & 4.6 & 2.5 \\
\hline \multicolumn{7}{|c|}{ (In percent of GDP, unless otherwise indicated) } \\
\hline \multicolumn{7}{|l|}{ Central government $\mathbf{3 /}$} \\
\hline Revenue and grants & & 16.8 & 18.5 & 18.4 & 18.5 & 18.7 \\
\hline Current expenditure & & 18.0 & 19.4 & 19.2 & 20.1 & 20.0 \\
\hline Capital expenditure and net lending & & 3.2 & 3.6 & 5.0 & 4.3 & 4.0 \\
\hline Primary balance & & -2.1 & -1.9 & -3.4 & -3.6 & -2.9 \\
\hline Overall balance & & -4.4 & -4.5 & -5.9 & -5.9 & -5.3 \\
\hline Central government debt & & 43.9 & 45.7 & 49.3 & 53.6 & 56.9 \\
\hline \multicolumn{7}{|l|}{ External sector $4 /$} \\
\hline Current account balance & & -10.5 & -14.0 & -14.1 & -13.6 & -12.7 \\
\hline \multicolumn{7}{|l|}{ Change in net international reserves } \\
\hline (increase -) & & -0.6 & -0.3 & 0.7 & -0.3 & -0.3 \\
\hline External public debt (end of period) & & 11.8 & 12.9 & 12.8 & 14.1 & 14.5 \\
\hline \multicolumn{7}{|l|}{ Memorandum items: 4/ } \\
\hline \multicolumn{7}{|l|}{ Gross international reserves } \\
\hline (end of period; millions of U.S. dollars) & & 860 & 885 & 829 & 855 & 884.8 \\
\hline In months of next year's G\&S imports & & 2.4 & 2.3 & 2.1 & 2.1 & 2.1 \\
\hline In months of next year's non-FDI related G\&S imports & & 4.5 & 4.5 & 4.0 & 4.0 & 3.9 \\
\hline In percent of reserve money & & 104 & 100 & 90 & 87 & 84 \\
\hline External debt-service ratio (in percent of exports of G\&S) & & 11.2 & 8.1 & 7.5 & 5.9 & 4.8 \\
\hline GDP (in millions of Bahamian dollars) & & 7,771 & 7,788 & 8,040 & 8,318 & 8,682 \\
\hline
\end{tabular}

Sources: Central Bank of The Bahamas; Department of Statistics; Ministry of Finance; UNDP Human Development Report; CIA World Factbook and Fund staff projections.

1/ Revised national accounts data.

2/ The 2011 figure is based on November survey and the 2012 figure is based on May survey.

3/ The data refer to fiscal years ending on June 30 .

4/ The data refer to calendar years. 


\section{Appendix Table 9. The Bahamas: Financial Soundness Indicators of the Onshore Banking System}

\begin{tabular}{|c|c|c|c|c|c|c|c|c|c|c|c|c|}
\hline & 2000 & 2001 & 2002 & 2003 & 2004 & 2005 & 2006 & 2007 & 2008 & 2009 & 2010 & 2011 \\
\hline \multicolumn{13}{|l|}{ Core Financial Soundness Indicators for Deposit Takers } \\
\hline Regulatory Capital to Risk-Weighted Assets & - & - & 17.1 & 19.8 & 20.1 & 19.1 & 16.9 & 18.0 & 22.6 & 27.4 & 26.0 & 27.6 \\
\hline Regulatory Tier 1 Capital to Risk-Weighted Assets & - & - & - & - & - & - & - & - & - & - & 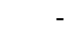 & 25.1 \\
\hline Non-performing Loans Net of Provisions to Capital & - & - & - & 13.1 & 10.9 & 11.2 & 7.8 & 9.5 & 12.8 & 20.2 & 23.6 & 24.1 \\
\hline Non-performing Loans to Total Gross Loans & - & - & 5.1 & 5.1 & 4.8 & 4.4 & 4.1 & 4.4 & 6.0 & 9.3 & 12.2 & 13.0 \\
\hline Sectoral Distribution of Total Loans: Residents & 93.9 & 95.1 & 93.9 & 94.3 & 94.2 & 88.4 & 88.8 & 89.0 & 89.7 & 89.9 & 90.8 & 91.3 \\
\hline Sectoral Distribution of Total Loans: Deposit-takers & 0.0 & 0.0 & 0.0 & 0.0 & 0.0 & 0.0 & 0.0 & 0.0 & 0.0 & 0.0 & 0.0 & 0.0 \\
\hline Sectoral Distribution of Total Loans: Central Bank & 0.0 & 0.0 & 0.0 & 0.0 & 0.0 & 0.0 & 0.0 & 0.0 & 0.0 & 0.0 & 0.0 & 0.0 \\
\hline Sectoral Distribution of Total Loans: Other Financial Corporations & 0.3 & 0.7 & 0.8 & 0.6 & 0.4 & 0.3 & 0.4 & 0.4 & 0.3 & 0.3 & 0.2 & 0.3 \\
\hline Sectoral Distribution of Total Loans: General Government & 5.5 & 5.9 & 8.1 & 9.1 & 8.1 & 7.1 & 6.4 & 5.1 & 6.5 & 5.1 & 7.0 & 6.4 \\
\hline Sectoral Distribution of Total Loans: Nonfinancial Corporations & 32.6 & 31.1 & 28.6 & 26.7 & 24.9 & 23.4 & 23.1 & 21.6 & 19.8 & 20.1 & 19.1 & 19.1 \\
\hline Sectoral Distribution of Total Loans: Consumer Loans & 35.1 & 34.5 & 31.8 & 30.2 & 30.6 & 28.2 & 28.5 & 29.5 & 29.7 & 29.1 & 28.7 & 29.1 \\
\hline Sectoral Distribution of Total Loans: Residential Mortgages & 20.5 & 23.0 & 24.6 & 27.7 & 30.3 & 29.4 & 30.3 & 32.4 & 33.4 & 35.2 & 35.8 & 36.5 \\
\hline Sectoral Distribution of Total Loans: Other Domestic Sectors & 0.0 & 0.0 & 0.0 & 0.0 & 0.0 & 0.0 & 0.0 & 0.0 & 0.0 & 0.0 & 0.0 & 0.0 \\
\hline Sectoral Distribution of Total Loans: Nonresidents & 6.1 & 4.9 & 6.1 & 5.7 & 5.8 & 11.6 & 11.2 & 11.0 & 10.3 & 10.1 & 9.2 & 8.7 \\
\hline Return on Assets & 3.8 & 2.8 & 2.5 & 1.8 & 3.0 & 4.5 & 3.7 & 3.4 & 2.5 & 2.3 & 2.7 & 2.5 \\
\hline Return on Equity & 32.9 & 27.1 & 28.1 & 9.8 & 17.4 & 28.8 & 20.5 & 18.2 & 14.5 & 11.8 & 15.1 & 13.4 \\
\hline Interest Margin to Gross Income & 53.1 & 54.5 & 51.3 & 50.6 & 54.8 & 58.3 & 53.3 & 53.8 & 55.9 & 59.3 & 61.0 & 64.2 \\
\hline Non-interest Expenses to Gross Income & 34.9 & 35.5 & 38.4 & 44.1 & 38.0 & 32.6 & 28.5 & 28.9 & 32.7 & 35.5 & 36.2 & 38.2 \\
\hline Liquid Assets to Total Assets (Liquid Asset Ratio) & 12.6 & 12.8 & 12.6 & 13.1 & 14.5 & 12.9 & 11.2 & 12.0 & 12.8 & 15.9 & 18.7 & 19.7 \\
\hline Liquid Assets to Short Term Liabilities & 17.9 & 18.0 & 17.9 & 20.9 & 23.7 & 21.5 & 19.2 & 18.6 & 20.7 & 26.4 & 31.7 & 30.1 \\
\hline \multicolumn{13}{|l|}{ Encouraged Financial Soundness Indicators for Deposit Takers } \\
\hline Trading and Fee Income to Total Income & 5.3 & 4.3 & 4.5 & 4.8 & 4.6 & 4.2 & 4.4 & 2.4 & 3.4 & 2.4 & 2.6 & 3.0 \\
\hline Personnel Expenses to Non-interest Expenses & 58.4 & 54.4 & 65.4 & 49.7 & 56.4 & 57.2 & 58.2 & 56.7 & 52.6 & 52.7 & 50.0 & 54.2 \\
\hline Spread Between Reference Lending and Deposit Rates & 7.9 & 6.8 & 7.3 & 8.1 & 7.1 & 6.7 & 6.3 & 6.9 & 6.5 & 6.8 & 8.2 & 8.6 \\
\hline Foreign-Currency-Denominated Liabilities to Total Liabilities & 29.1 & 26.1 & 40.5 & 41.7 & 42.4 & 40.2 & 39.6 & 36.5 & 32.7 & 29.8 & 28.6 & 26.4 \\
\hline
\end{tabular}


AnNeXes: ObServance OF Financial Sector StAndards ANd CODES-Summary ASSESSMENTS

This Annex contains the summary assessments of the Central Bank of The Bahamas's observance of financial standards and codes. These assessments help identify the main strengths of the supervisory, regulatory and market infrastructure framework in managing potential risks and vulnerabilities in the financial system. They also point to areas that need strengthening and further reform.

These summaries are based on detailed assessments of the following international standards:

- $\quad$ Basel Core Principles (BCP) for Effective Banking Supervision - by

José Tuya (external expert) and Michael Deasy (external expert).

- $\quad$ IAIS Insurance Core Principles (ICP) - by Rodolfo Wehrhahn (IMF) and Christina Urias (external expert).

- IOSCO Principles and Objectives of Securities Regulation - by Richard Britton (external expert). 


\section{Annex I. Basel Core Principles for Effective Banking SuPervision}

\section{A. Introduction}

1. This assessment of the Basel Core Principles for Effective Banking Supervision (BCP) was conducted from July 9 through July 24, 2012. As agreed with the authorities, the supervisory framework was assessed against the $\mathrm{BCP}$ methodology issued by the Basel Committee on Banking Supervision (BCBS) in October 2006. The CBoB is the sole supervisor of the banking system and as such, the assessment covers only the $\mathrm{CBoB}$. An OFC assessment was conducted in 2004; however, the grading is not comparable to this assessment as the principles and methodology were revised in 2006. The assessment was performed by consultants Michael Deasy (formerly with the Central Bank of Ireland) and José Tuya (formerly with the Office of the Comptroller of the Currency, USA).

\section{Since the IMF OFC Assessment in 2004, there have been significant reforms} implemented. In its efforts to implement international standards, the $\mathrm{CBoB}$ has increased its focus on anti-money laundering, tightened the licensing process and made reforms in its banking supervision approach. Important features of the new supervisory and regulatory regime now include broader and more uniform supervision of bank and nonbank financial activities and stronger mechanisms for international cooperation among Bahamian authorities and their foreign counterparts. The $\mathrm{CBoB}$ has implemented a risk-based bank rating system to aid in the targeting of supervisory activities to the higher risk areas.

3. In conducting the assessment a number of information sources were reviewed and significant reliance was placed on the authorities' self-assessment. The selfassessment was thorough and facilitated the BCP review. In addition to reviewing the selfassessment, the assessors reviewed the responses to a questionnaire sent to the authorities as part of the information gathering process which requested more detailed information to support the self-assessment. The $\mathrm{BCP}$ assessment included meetings with $\mathrm{CBoB}$ supervisory, legal and policy staff and meetings with commercial banks, the bankers' association, the accounting association, an accounting firm and the MoF. Open access was provided to review inspection reports, licensing and enforcement documents and on-line presentations on the supervisory process so that assessors could evaluate that a review of bank compliance with requirements was effected by the $\mathrm{CBoB}$.

4. The assessors appreciated the collaboration and hospitality of the CBoB. The staff always made itself available to discuss the principles and greatly facilitated the $\mathrm{BCP}$ assessment. Coordination of meetings, obtaining additional information and responding to ad hoc inquiries was managed in an extremely efficient and professional manner. 


\section{B. Background}

5. The financial system is exceptionally large, reflecting the country's role as a major OFC. It comprises domestic and offshore banks and trust companies, insurance companies (both domestic and external), pension funds, credit unions, and other nonbank intermediaries. At end-2011, there were 271 banks and trust companies with active licenses, of which, 155 are restricted (mainly nominee trust companies). Banks licensed in the Bahamas hold B \$595 billion in assets (76 times GDP). Offshore banks account for some 98 percent of the total. The $\mathrm{CBoB}$ is the home country supervisor and responsible for consolidated supervision of, three indigenous, deposit-taking commercial banks.

6. The Bahamas is the fourth largest OFC (after the Cayman Islands, Hong Kong SAR, and Singapore). At end-2011, Bahamian banks held 12 percent of all foreign assets held by banks in OFCs worldwide. In March 2012, the foreign assets of offshore banks registered in The Bahamas amounted to US $\$ 501.2$ billion.

7. The domestic (commercial/onshore) banking sector and the international (offshore) financial center are essentially fully segmented, with claims limited to a very modest amount of intra-group lending operations. Offshore entities are prohibited from holding balances in Bahamian dollars except to finance local expenses and cannot invest in domestic securities. They have extremely limited exposure to domestic real estate markets amid strict capital controls enacted by the $\mathrm{CBoB}$, although occasionally they may assist high net worth individual clients in acquiring real estate in The Bahamas.

8. Commercial banks are primarily funded by deposits and equity (71 percent and 18 percent respectively). Capital market and interbank market funding is currently negligible. The share of equity funding has increased since 2003, partly due to conversion of foreign branches into subsidiaries. The corresponding capital injections accompanying the subsidiarization have replaced liquidity provision from parents.

9. The commercial banks engage in traditional banking activities, primarily providing residential mortgages and consumer finance to Bahamian residents. Domestic residential mortgages account for about 23 percent of the banks' assets. Other loans, including consumer, commercial and non-resident loans, accounted for about 36 percent of the total assets in March 2012. Exposure of the commercial banks to the public sector has increased significantly since 2008 to 14 percent of total assets, as the commercial banks have absorbed a large part of government securities issued since then.

10. Financial supervision is performed by three separate institutions: the $\mathrm{CBoB}$, the Insurance Commission of The Bahamas (ICB), and the SCB. Supervisory coordination takes place through regular meetings of the GFSR, consisting of the $\mathrm{CBoB}$, the $\mathrm{SCB}$, the $\mathrm{ICB}$, the Inspector of Financial and Corporate Services, and the Compliance Commission. 
The GFSR is chaired by the $\mathrm{CBoB}$ and has been working towards greater harmonization of the regulatory system.

\section{The Bahamian economy has continued its recovery from the global financial} crisis. A collapse in tourism led to a 5.4 percent decline in output in 2009 , but the economy has gradually picked up and GDP is expected to grow about 2.5 percent in 2012 , due to a rebound in tourism and to large foreign and public investment projects (including the US\$3.5 billion Baha Mar project). Substantial FDI-related imports and higher oil prices will widen the external current account deficit in 2012, but reserves are expected to remain reasonably strong. Downside risks to growth stem from the country's high dependence on tourism, which could be disrupted by a weakening of the U.S. economy, a prolonged increase in oil prices, or a large-scale hurricane.

\section{The Bahamas has a well-developed legal framework that provides adequate} support for banking supervision. The $\mathrm{CBoB}$ can operate independently and has the authority to impose sanctions, take preventive corrective action and resolve weak banks, including revocation of the license. A deposit insurance system is in place to protect Bahamian dollar deposits.

13. A credit bureau system is not operational in The Bahamas. The authorities are reviewing options for the establishment of a credit bureau to enable banks to better determine a prospective borrower's total indebtedness. A draft Credit Reporting Bill, 2012 has been prepared and is currently under review by the authorities.

\section{Findings}

\section{Significant changes have occurred in The Bahamas financial system and the} supervisory regime in recent years. There have been amendments to the CBoB Act, 2000 (CBBA) and the Bank and Trust Companies Regulation Act (BTCRA) to broaden the CBoB information sharing authority, and strengthen supervisory enforcement powers. A risk assessment process was introduced in the last quarter of 2010 which reviews all risk areas and assigns ratings to aid in establishing supervisory priorities. Shell banks are no longer permitted to operate in The Bahamas.

15. The onshore banking system is well capitalized, liquid, and profitable, but credit risk should continue to be monitored closely, especially in view of ongoing economic uncertainties. High NPL ratios remain the key challenge for the onshore banking system, particularly for mortgages, which constitute over half of NPLs. However, the authorities remain vigilant about the potential impact of NPLs on bank capital and have substantially improved credit risk monitoring of onshore commercial banks. Requirements and practices on provisioning and asset impairments are in compliance with international standards. Nonetheless, there is some degree of uncertainty on the overall evolution of house prices since reliable house price indices are not available and there are relatively few transactions 
on which to base firm judgments, although independent valuations are required for problem mortgages

16. There is no obvious near-term threat to bank stability since banks are very well capitalized (both in terms of quantity and quality of capital), profitable, and highly reliant on deposits and equity, which substantially limits funding risks. Stress tests confirm that the commercial banks can withstand severe shocks in terms of both solvency and liquidity, though banks are heterogeneous in their performance.

17. Capital ratios are calculated in accordance with Basel I. However, since 2005 the Central Bank has been steadily and progressively working on completing the requirements for compliance with Basel II Pillar II-Supervisory Review. As of last quarter of 2010, the commencement of the roll-out of the enhanced risk based framework (incorporating the comprehensive risk assessment tool), formalized the CBoB's approach with Pillar II expectations.

18. There have been significant enhancements to the risk management guidance issued to banks and the supervision of those risks. Nonetheless, because capital ratios are calculated in accordance with Basel I, there is no specific capital cover for specific risks, e.g., market risk, operational risk, etc. The level of ratios among the banks, however, is very high and would compensate for the lack of specific cover for these risks. $\mathrm{CBoB}$ will be implementing the capital charges for market risks commencing the third quarter of 2012, thus completing the requirements for full compliance with Basel I. To date its risk based framework meets the expectations for Basel II-Pillar II as it relates to certain aspects of Supervisory Review. Pillar III-Minimum Disclosures is due to be implemented before yearend 2012. Focused efforts will be given to consulting and implementing Pillar I requirements by the beginning of the third quarter of 2013. Regarding Basel III, banks have been sensitized to the requirements and $\mathrm{CBoB}$ intends to consult the stakeholders regarding its positions on same by end 2013.

19. СВОВ has a cohort of knowledgeable and dedicated staff in place. At the same time it should consider recruiting additional staff, particularly specialist staff, to meet the demands of an ever increasingly complex supervisory environment. 


\section{Annex Table 1. The Bahamas: Summary Compliance with the Basel Core Principles-ROSCs}

\begin{tabular}{|c|c|}
\hline Core Principle & Comments \\
\hline \multicolumn{2}{|l|}{$\begin{array}{l}\text { 1. Objectives, independence, powers, } \\
\text { transparency, and cooperation }\end{array}$} \\
\hline \multicolumn{2}{|l|}{ 1.1 Responsibilities and objectives } \\
\hline $\begin{array}{l}1.2 \text { Independence, accountability and } \\
\text { transparency }\end{array}$ & $\begin{array}{l}\text { CBoB should consider recruiting more staff, } \\
\text { including specialists. } \\
\text { The reasons for the removal of the Governor should } \\
\text { be publicly disclosed. }\end{array}$ \\
\hline \multicolumn{2}{|l|}{ 1.3 Legal framework } \\
\hline \multicolumn{2}{|l|}{ 1.4 Legal powers } \\
\hline \multicolumn{2}{|l|}{ 1.5 Legal protection } \\
\hline \multicolumn{2}{|l|}{ 1.6 Cooperation } \\
\hline 2. Permissible activities & $\begin{array}{l}\text { In publishing the quarterly list of banks, CBoB should } \\
\text { have two sections, one listing only banks (including } \\
\text { banks that carry on trust business) and the other } \\
\text { listing trust companies. }\end{array}$ \\
\hline 3. Licensing criteria & $\begin{array}{l}\text { While noting that no 'restricted banking licenses' } \\
\text { have been issued in recent years, CBoB should } \\
\text { avoid issuing any such licenses in the future. They } \\
\text { are not banks in the true sense as they do not take } \\
\text { deposits from the public at large. }\end{array}$ \\
\hline \multicolumn{2}{|l|}{ 4. Transfer of significant ownership } \\
\hline \multicolumn{2}{|l|}{ 5. Major acquisitions } \\
\hline . Capital adequacy & $\begin{array}{l}\text { Capital ratios are calculated in accordance with } \\
\text { Basel I. Consequently, there is no specific capital } \\
\text { cover for specific risks, e.g., market risk, operational } \\
\text { risk, etc. The level of ratios among the banks, } \\
\text { however, is very high and would compensate for the } \\
\text { lack of specific cover for these risks. } \\
\text { CBoB will be implementing the capital charges for } \\
\text { market risks commencing the third quarter of } 2012 \text {, } \\
\text { thus completing the requirements for full compliance } \\
\text { with Basel I. To-date its risk based framework meets } \\
\text { the expectations for Basel II-Pillar II as it relates to } \\
\text { certain aspects of Supervisory Review. } \\
\text { Pillar III-Minimum Disclosures is due to be } \\
\text { implemented before year end } 2012 \text {. Focused efforts } \\
\text { will be given to consulting and implementing Pillar I } \\
\text { requirements by the beginning of the third quarter of } \\
2013 \text {. }\end{array}$ \\
\hline
\end{tabular}




\begin{tabular}{|c|c|}
\hline & $\begin{array}{l}\text { Regarding Basel III, banks have been sensitized to } \\
\text { the requirements and CBoB intends to consult the } \\
\text { stakeholders regarding its positions on same by end } \\
2013 \text {. }\end{array}$ \\
\hline 7. Risk management process & $\begin{array}{l}\text { Issue pending guidance on interest, market and } \\
\text { operational risks. Finalize and implement onsite } \\
\text { examination templates for reflecting the risk-based } \\
\text { approach. }\end{array}$ \\
\hline \multicolumn{2}{|l|}{ 8. Credit risk } \\
\hline \multicolumn{2}{|l|}{ 9. Problem assets, provisions, and reserves } \\
\hline \multicolumn{2}{|l|}{ 10. Large exposure limits } \\
\hline 11. Exposure to related parties & $\begin{array}{l}\text { The CBOB should include in its supervisory process } \\
\text { as a matter of urgency an examination of compliance } \\
\text { with the following recently introduced requirements: } \\
\text { (i) transactions with related parties and the write-off } \\
\text { of related exposures exceeding specified amounts or } \\
\text { otherwise posing special risk be subject to prior } \\
\text { approval by the bank's Board, (ii) Board members } \\
\text { with conflicts of interest be excluded from the } \\
\text { approval, and (iii) banks have policies and processes } \\
\text { in place to prevent persons benefiting from the } \\
\text { exposures and/or persons related to such a person } \\
\text { from being part of the process of granting and } \\
\text { managing the exposure. }\end{array}$ \\
\hline \multicolumn{2}{|l|}{ 12. Country and transfer risks } \\
\hline 13. Market risks & $\begin{array}{l}\text { Issue pending guidance on interest, market and } \\
\text { operational risks. }\end{array}$ \\
\hline \multicolumn{2}{|l|}{ 14. Liquidity risk } \\
\hline 15. Operational risk & $\begin{array}{l}\text { Issue pending guidelines and finalize onsite } \\
\text { examination templates. Add information technology } \\
\text { (IT) expertise to the CBoB staffing. }\end{array}$ \\
\hline 16. Interest rate risk in the banking book & $\begin{array}{l}\text { Issue pending guidelines and finalize onsite } \\
\text { examination templates. }\end{array}$ \\
\hline 17. Internal control and audit & $\begin{array}{l}\text { A requirement should be introduced for banks to } \\
\text { inform CBoB if they become aware of any material } \\
\text { information which may negatively affect the fitness } \\
\text { and propriety of a Board member or a member of } \\
\text { senior management. }\end{array}$ \\
\hline \multicolumn{2}{|l|}{ 18. Abuse of financial services } \\
\hline 19. Supervisory approach & $\begin{array}{l}\text { Develop benchmarks and guidance to aid examiners } \\
\text { in assessing the adequacy of bank developed risk } \\
\text { management policies/practices. }\end{array}$ \\
\hline \multicolumn{2}{|l|}{ 20. Supervisory techniques } \\
\hline 21. Supervisory reporting & $\begin{array}{l}\text { Consider increasing the penalty of } \$ 250 \text { per day for } \\
\text { the late submission of reports. }\end{array}$ \\
\hline \multicolumn{2}{|l|}{ 22. Accounting and disclosure } \\
\hline $\begin{array}{l}\text { 23. Corrective and remedial powers of } \\
\text { supervisors }\end{array}$ & $\begin{array}{l}\text { Implement proposed amendments to the BTCRA on } \\
\text { administrative penalties for individuals. }\end{array}$ \\
\hline
\end{tabular}


24. Consolidated supervision

Develop detailed guidelines to address application of regulations and supervision on a consolidated basis

25. Home-host relationships to a banking group.

\section{Annex Table 2. The Bahamas: Recommended Action Plan to Improve Compliance with the Basel Core Principles}

\begin{tabular}{|c|c|}
\hline Reference Principle & Recommended Action \\
\hline CPs 7,13 and 16 & $\begin{array}{l}\text { Issue and implement draft guidance on bank responsibilities for } \\
\text { managing interest and market risk. }\end{array}$ \\
\hline CP 15 & $\begin{array}{l}\text { Hire IT expertise to provide support for examiners reviewing } \\
\text { banks' compliance with corporate governance, business } \\
\text { continuity plans and outsourcing guidelines. Issue and implement } \\
\text { draft operational risk guidelines. }\end{array}$ \\
\hline CP 19 & $\begin{array}{l}\text { The CBoB supervisory approach requires banks to establish risk } \\
\text { management practices reflecting the bank's risk profile. The } \\
\text { CBoB should develop benchmarks to aid examiners in gauging } \\
\text { the adequacy of bank policies. }\end{array}$ \\
\hline CP 24 & $\begin{array}{l}\text { Develop guidelines on the scope and methods of supervision for } \\
\text { consolidated supervision. The consultation paper The Supervision } \\
\text { of Financial Conglomerates in the Bahamas provides a foundation } \\
\text { for such guidelines. }\end{array}$ \\
\hline CP 1(2) & $\begin{array}{l}\text { Recruit additional staff with particular emphasis on specialists. } \\
\text { Amend legislation so that the reasons for the removal of the } \\
\text { Governor would be publicly disclosed. }\end{array}$ \\
\hline CP 6 & $\begin{array}{l}\text { Adopt Basel III as a matter of urgency so that risks such as } \\
\text { market risk and operational risk would be specifically supported } \\
\text { by capital. }\end{array}$ \\
\hline CP 11 & $\begin{array}{l}\text { Include in the supervisory process as a matter of urgency an } \\
\text { examination of compliance with the following recently introduced } \\
\text { requirements: (i) transactions with related parties and the write-off } \\
\text { of related exposures exceeding specified amounts or otherwise } \\
\text { posing special risk be subject to prior approval by the bank's } \\
\text { Board, (ii) Board members with conflicts of interest be excluded } \\
\text { from the approval, and (iii) banks have policies and processes in } \\
\text { place to prevent persons benefiting from the exposures and/or } \\
\text { persons related to such a person from being part of the process of } \\
\text { granting and managing the exposure. }\end{array}$ \\
\hline
\end{tabular}




\begin{tabular}{|l|l|}
\hline \multicolumn{1}{|c|}{ Reference Principle } & \multicolumn{1}{c|}{ Recommended Action } \\
\hline CPs 2 and 3 & $\begin{array}{l}\text { Distinguish between banks and trust companies when providing a } \\
\text { public listing of banks. } \\
\text { Consideration should be given to stop issuing restricted banking } \\
\text { licenses. }\end{array}$ \\
\hline
\end{tabular}

\section{Authorities' Response to the Assessment}

20. The $\mathrm{CBoB}$ would like to convey its appreciation to the IMF FSAP Mission for this comprehensive and balanced assessment of The Bahamas' compliance with the Basel Core Principles for Effective Banking Supervision. The assessors broadly recognize that The Bahamas has in place a very strong legal and regulatory framework for banking supervision, and we appreciate the assessors' recommendations that guidelines and policies be further enhanced to reflect our current supervisory practices which, in themselves, are commensurate with international best practices. These expectations are aligned with the $\mathrm{CBoB}$ 's ongoing commitment to ensure the robustness of our regime.

21. As recognized in the assessment, a number of initiatives are already underway that will allow The Bahamas to enhance its banking supervision legislative regime and policy framework.

22. The Bank intends to have the draft Banks and Trust Companies Regulation (Amendment) Bill, 2012 enacted and to bring the draft Banks and Trust Companies (Administrative Monetary Penalties) Regulations, 2012 (the Regulations) into force in the near future, given that the industry consultation on the drafts is now complete. The draft Bill will strengthen and clarify the Central Bank's existing penalties enforcement regime by empowering the Central Bank to impose administrative monetary penalties or fines on any person or licensee in respect of the contravention of the Banks and Trust Companies Regulation Act, 2000 (the Act) or regulations made under the Act.

23. The proposed amendments to the Act also include enhanced fit and proper requirements, new provisions relating to controllers of licensees, and new provisions which would empower the Central Bank to impose prohibition orders against persons performing regulated functions, where such persons do not, or no longer, meet the Bank's fit and proper requirements.

24. When enacted and brought into force, the draft Banks and Trust Companies Regulation (Amendment) Bill, 2012 and the draft Banks and Trust Companies (Administrative Monetary Penalties) Regulations, 2012 will enhance the Central Bank's compliance with Basel Core Principles. 
25. The CBoB has worked aggressively over the years on the Risk Based Supervisory Framework, which has established the foundation of our approach to Pillar II requirements under the Basel II regime. A significant next step will be the alignment of this framework with the broader initiation of the Basel II-ICAAP program. The $\mathrm{CBoB}$ has made tremendous strides toward implementation of its market risk regime, having recently piloted the reporting forms and guidance notes with all the licensees that met the de minimis threshold. Also, the $\mathrm{CBoB}$ is at an advance stage of releasing, in final, its guidance document on Interest Rate Risk, which has already undergone the industry consultative process.

26. In the immediate future, the Central Bank will commence industry consultation on several key draft policy guidelines, i.e., Market Risk, Operational Risk and Minimum Disclosures. The latter of course, will set out the minimum requirements for Pillar III disclosures. Given the number of work streams underway, we are optimistic that, in the coming weeks and months, we would have successfully implemented these outstanding policy development initiatives. To ensure that we are able to deliver on our planned enhancements to banking supervision, the $\mathrm{CBoB}$ is already assessing its supervisory resource requirements and, at the same time, leveraging technology to achieve efficiency savings. 


\section{ANNeX II. ObSERvance of the IAIS Insurance CoRe PrinciPles}

\section{A. Introduction and Scope}

27. This report is a full assessment of The Bahamas's compliance with the Insurance Core Principles (ICPs) of the International Association of Insurance Supervisors (IAIS), as adopted in October 2011. The review was carried out as part of the 2012 Financial Sector Assessment Program (FSAP) assessment of The Bahamas, and was based on the regulatory framework in place, the supervisory practices employed, and other conditions as they existed in July 2012. The assessment was carried out by Mr. Rodolfo Wehrhahn, Technical Assistance Advisor in the Financial Supervision and Regulation Division, a part of the Monetary and Capital Markets Department, IMF and Ms. Christina Urias, former Insurance Commissioner, Consultant.

28. Regulation and supervision of the insurance industry in The Bahamas is the responsibility of the newly established Insurance Commission of The Bahamas (ICB). The ICB is the ultimate supervisory authority of the insurance sector that includes insurers, brokers, agents, salesmen, underwriting managers and external insurers (see External Insurance Act 2009). This assessment focuses on the ICB.

29. The assessment is based solely on the laws, regulations, and other supervisory requirements and practices that were in place at the time of assessment. Ongoing regulatory initiatives are noted by way of additional comments. The assessors met with staff from the ICB and the Ministry of Finance (MoF), insurers, industry associations, professional bodies and audit firms. The assessors are grateful for the full cooperation extended by all.

\section{B. Executive Summary}

30. Insurance supervision in The Bahamas has significantly improved in the past few years, fostered by the enactment of insurance legislation in 2009 and the creation of the ICB with a highly qualified staff and the power and independence to properly supervise the industry. The amount of infrastructure and processes created in the short time since enactment is commendable. Actions taken by the ICB have already had a very positive impact on the insurance market in The Bahamas. These include the following: (i) a major clean up of non active insurers has taken place; (ii) the overdue premium receivables have dropped dramatically with the introduction of a penalty for receivables beyond 30 days; (iii) financial requirements for insurers, brokers and agents have been put in place and have been enforced; (iv) quarterly supervisory meetings with insurers are taking place; and (v) annual stress testing is required for life insurers.

31. Risk-based supervision (RBS) is still in its initial stages and essential onsite and offsite supervisory tools for proper supervision need development. Also a standardized risk sensitive solvency framework needs to be fully implemented. The ICB is aware of the 
drawbacks of such a simplistic solvency regime and for the large life insurers it has required independent consultant actuaries to calculate the minimum capital requirement (MCR) based on the Canadian solvency regime. The ICB is making progress in developing ladders of intervention within its solvency framework for the exercise of progressive escalation of regulatory and remedial intervention.

\section{ICB needs to enhance its market conduct supervision to improve consumer}

protection regulation. The ICB's consumer protection activities are only just beginning and disclosure requirements are under development that will allow the ICB to obtain, track and analyze the nature, scope and quantity of consumer complaints and identify the companies involved. Insurers are required to establish procedures to provide disclosure of information to customers and to deal with customer complaints, but there are no specific requirements for claims handling practices.

\section{Summary of Observance of the Insurance Core Principles}

\section{Annex Table 3. The Bahamas: Summary of Observance of the Insurance Core Principles}

\begin{tabular}{|l|l|}
\hline \multicolumn{1}{|c|}{ Insurance Core Principle } & \multicolumn{1}{c|}{ Overall Comments } \\
\hline $\begin{array}{l}\text { 1. Objectives, Powers and } \\
\text { Supervisor }\end{array}$ & $\begin{array}{l}\text { The authority responsible for insurance supervision is the ICB as } \\
\text { stated in the law. The ICB's responsibility for insurance supervision } \\
\text { and objectives of supervision are well defined. }\end{array}$ \\
\hline 2. Supervisor & $\begin{array}{l}\text { The ICB governance structure is strong with an active independent } \\
\text { board where the ultimate power and decisions reside. Not all } \\
\text { operational decisions have been delegated to the Superintendent. } \\
\text { This can cause delays and reduce efficiency. The appointment of } \\
\text { the Board members coinciding with each other and with the election } \\
\text { cycle creates governance discontinuity and the independence of the } \\
\text { board could also be affected. The reasons for removal of Board } \\
\text { members or Superintendent are not published. }\end{array}$ \\
& $\begin{array}{l}\text { The ICB operating as an autonomous statutory corporation and has } \\
\text { full operational autonomy in respect of its expenditure, including } \\
\text { staff remuneration. }\end{array}$ \\
\hline 3. Information Exchange & $\begin{array}{l}\text { The ICB has the legal and regulatory authority to obtain and share } \\
\text { information with other relevant supervisors and authorities, subject } \\
\text { to the necessary confidentiality, purpose and use requirements, as } \\
\text { may be necessary to discharge its regulatory duties. Current } \\
\text { Requirements }\end{array}$ \\
$\begin{array}{l}\text { legislation however, does not provide the ICB with the authority to } \\
\text { obtain information from unregulated entities belonging to an } \\
\text { insurance or financial group. }\end{array}$ \\
\hline 4. Licensing & $\begin{array}{l}\text { No entity may carry on insurance business without registration and } \\
\text { proper license from the ICB. }\end{array}$ \\
\hline 5. Suitability of Persons & $\begin{array}{l}\text { The ICB regulations outline fit and proper requirements for the } \\
\text { beneficial owners and Managing Director, Chief Executive Officer or } \\
\text { Principal Representative. Other key functionaries, such as auditors, }\end{array}$ \\
\hline
\end{tabular}




\begin{tabular}{|c|c|}
\hline & $\begin{array}{l}\text { actuaries and persons in charge of underwriting, claims, agency, } \\
\text { investment and accounting activities are also required to meet fit } \\
\text { and proper requirements. }\end{array}$ \\
\hline $\begin{array}{l}\text { 6. Changes in Control and } \\
\text { Portfolio Transfers }\end{array}$ & $\begin{array}{l}\text { The Insurance Act requires the insurer to obtain ICB approval before } \\
\text { any changes in beneficial ownership and persons eligible to } \\
\text { exercise control over the insurer. As to external company acquisition } \\
\text { requests, ICB conducts similar fit and proper evaluations. } \\
\text { The Insurance Act sets the minimum capital required for various } \\
\text { license types; however, the ICB has the authority and requires } \\
\text { capital to be commensurate with the company's business plan. }\end{array}$ \\
\hline 7. Corporate Governance & $\begin{array}{l}\text { There are no specific provisions in the legislation that explicitly } \\
\text { require the Board to set and oversee the implementation of the } \\
\text { insurers' business objectives and strategies, including risk } \\
\text { management. The ICB does not require the insurer to have an } \\
\text { internal audit function and although the regulation does provide for } \\
\text { adequate powers of the Board, it does not address ICB authority to } \\
\text { appoint and dismiss board members. }\end{array}$ \\
\hline $\begin{array}{l}\text { 8. Risk Management and } \\
\text { Internal Controls }\end{array}$ & $\begin{array}{l}\text { There are no regulations or formal policies requiring effective risk } \\
\text { management. Further, there are no requirements for the insurer to } \\
\text { have effective control functions with the necessary authority, } \\
\text { independence and resources. }\end{array}$ \\
\hline $\begin{array}{l}\text { 9. Supervisory Review and } \\
\text { Reporting }\end{array}$ & $\begin{array}{l}\text { During the later part of 2010, the ICB commenced Phase } 1 \text { of a } 3 \\
\text { year implementation plan for its RBS framework, which focuses on } \\
\text { enhancing offsite monitoring to increase the supervisor's knowledge } \\
\text { of the insurers' business. The material and steps are in the right } \\
\text { direction but they are too recent to assess its effectiveness. } \\
\text { The legislation does not specifically grant the ICB the authority to } \\
\text { examine an insurer's outsourcing function and such information is } \\
\text { necessary to assure compliance with ICB regulations. }\end{array}$ \\
\hline $\begin{array}{l}\text { 10. Preventive and } \\
\text { Corrective Measures }\end{array}$ & $\begin{array}{l}\text { Although the ICB has cease and desist powers and can impose } \\
\text { fines and penalties on licensees, it does not have the express power } \\
\text { to investigate unlicensed activity by unlicensed individuals or } \\
\text { entities. } \\
\text { The Insurance Act provides ICB with the authority to take timely } \\
\text { preventative and corrective action, but ICB resources are limited and } \\
\text { the ICB's ability to take timely preventive actions could be improved. }\end{array}$ \\
\hline 11. Enforcement & $\begin{array}{l}\text { The ICB has used its powers with respect to several licensees and } \\
\text { corrective and preventative measures have ranged from more } \\
\text { frequent reporting and monitoring to requiring additional capital, } \\
\text { asset diversification, orders to cease writing new business and } \\
\text { putting a company under statutory administration. }\end{array}$ \\
\hline $\begin{array}{l}\text { 12. Winding-up and Exit } \\
\text { from the Market }\end{array}$ & $\begin{array}{l}\text { The Companies Act provides the general requirements for winding } \\
\text { up procedures and the Insurance Act takes priority unless otherwise } \\
\text { specified. In the event of a winding up procedure, policyholders get } \\
\text { first priority in the liquidation scheme and are protected ahead of } \\
\text { other creditors. }\end{array}$ \\
\hline 13. Reinsurance and Other & The ICB is strongly engaged in reinsurance supervision and has \\
\hline
\end{tabular}




\begin{tabular}{|c|c|}
\hline Forms of Risk Transfer & $\begin{array}{l}\text { conducted a market-wide analysis on the sufficiency and } \\
\text { effectiveness of the reinsurance programs. The reinsurance market } \\
\text { in The Bahamas operates with cash call events and liquidity has not } \\
\text { been a problem in the recent catastrophic events. }\end{array}$ \\
\hline 14. Valuation & $\begin{array}{l}\text { Regulation requires for the valuation of the liabilities of long-term } \\
\text { insurers to be actuarially determined and consistent with best } \\
\text { practices. The majority of the insurers use Canadian actuaries that } \\
\text { apply the gross premium methodology. However there are other } \\
\text { insurers using actuaries from other jurisdictions calculating the } \\
\text { liabilities in compliance with the regulation. The lack of a common } \\
\text { standard creates uncertainty of the valuation and does not allow for } \\
\text { a proper market comparison. } \\
\text { Regulatory requirements on the calculation of the policyholder's } \\
\text { liabilities for general insurers are not in line with modern actuarial } \\
\text { practices and could be underestimating the real liabilities. }\end{array}$ \\
\hline 15. Investment & $\begin{array}{l}\text { The ICB requires that insurers' investments are managed following } \\
\text { the prudent person approach and this responsibility is assigned to } \\
\text { the board. } \\
\text { The regulatory investment requirements address indirectly security } \\
\text { and liquidity of the investments through the reduction in value of } \\
\text { admissible and qualifying assets for solvency purposes. }\end{array}$ \\
\hline $\begin{array}{l}\text { 16. Enterprise Risk } \\
\text { Management for Solvency } \\
\text { Purposes }\end{array}$ & $\begin{array}{l}\text { The ICB is in the beginning stages of developing its RBS framework } \\
\text { and does not yet have in place the regulatory authority, policies and } \\
\text { practices for risk management oversight as required under ICP } 16 \text {. }\end{array}$ \\
\hline 17. Capital Adequacy & $\begin{array}{l}\text { The current solvency regime uses a simple factors based test. The } \\
\text { ICB is aware of the drawbacks of such a simplistic solvency regime } \\
\text { and for the large life insurers it has required independent actuaries } \\
\text { to calculate the MCR based on the Canadian solvency regime. } \\
\text { Going forward ICB is developing a risk-sensitive solvency } \\
\text { framework. }\end{array}$ \\
\hline 18. Intermediaries & $\begin{array}{l}\text { The ICB has thorough supervisory review processes over } \\
\text { intermediaries in place under the new legislation. As to enforcement } \\
\text { actions, the ICB closed down an intermediary's operation and } \\
\text { revoked the license on breach of trust grounds. } \\
\text { Although intermediaries can be owners of insurance companies, } \\
\text { regulations do not allow them to serve on the boards of directors. }\end{array}$ \\
\hline 19. Conduct of Business & $\begin{array}{l}\text { The regulation (Regulation 16(i)) requires insurers to establish } \\
\text { procedures to provide disclosure of information to customers and to } \\
\text { deal with customer complaints. The ICB does not have any staff for } \\
\text { complaint handling and although the legislation affords the ICB with } \\
\text { the authority to conduct arbitrations, it does not do so at this stage. }\end{array}$ \\
\hline 20. Public Disclosure & $\begin{array}{l}\text { The majority of insurers' annual reports, financial statements and } \\
\text { balance sheets are published. ICB does not require publication of } \\
\text { the insurer's solvency position, claims, complaints, auditor } \\
\text { management statements, nor off balance sheet information and } \\
\text { should enhance the regulatory requirements accordingly. }\end{array}$ \\
\hline 21. Countering Fraud in & The legislation addresses fraud, and the Penal Code explicitly \\
\hline
\end{tabular}




\begin{tabular}{|l|l|}
\hline Insurance & $\begin{array}{l}\text { mentions insurance fraud. However, specific, documented } \\
\text { requirements for combating fraud are necessary. Legislation may } \\
\text { be needed to assure qualified immunity protection to the ICB } \\
\text { because of the confidential nature of the information. }\end{array}$ \\
\hline $\begin{array}{l}\text { 22. Anti-Money Laundering } \\
\text { and Combating the } \\
\text { Financing of Terrorism }\end{array}$ & $\begin{array}{l}\text { The Financial Action Task Force (FATF) representative made 40 } \\
\text { recommendations in its last review and ICB/Bahamas is due for its } \\
\text { next assessment within } 18 \text { months of the conclusion of the FSAP } \\
\text { mission. }\end{array}$ \\
\hline 23. Group-wide Supervision & $\begin{array}{l}\text { The ICB's regulatory framework for group supervision requires } \\
\text { further development. ICB does not have regulatory authority for } \\
\text { group supervision or to impose group solvency requirements and } \\
\text { should develop regulations for appropriate group supervision in } \\
\text { accordance with the ICPs. }\end{array}$ \\
\hline $\begin{array}{l}\text { 24. Macroprudential } \\
\text { Surveillance and Insurance }\end{array}$ & $\begin{array}{l}\text { ICB is in the initial development stage of its RBS framework and is } \\
\text { beginning to collect standardized data to identify trends and market } \\
\text { impacts. Ad hoc reports from insurers on specific market topics will } \\
\text { assist ICB in evaluating specific market issues, but thus far these } \\
\text { are on a relatively small scale and are only for specific events and } \\
\text { topics. }\end{array}$ \\
\hline $\begin{array}{l}\text { 25. Supervisory } \\
\text { Cooperation and } \\
\text { Coordination }\end{array}$ & $\begin{array}{l}\text { The ICB has informal cross-border arrangements with involved } \\
\text { supervisors on cross-border issues, however formal group-wide } \\
\text { supervision processes are not yet fully developed. The ICB has only } \\
\text { recently taken on the role as lead supervisor for the college formed } \\
\text { to review the activities of one of its largest financial } \\
\text { conglomerates/groups and is responsible for acting as chairman of } \\
\text { the supervisory college. }\end{array}$ \\
\hline $\begin{array}{l}\text { 26. Cross-border } \\
\text { Cooperation and } \\
\text { Moordination on Crisis } \\
\text { Management } \\
\text { theire are no requirements for contingency planning for insurers to } \\
\text { guarantee the availability of the information under severe } \\
\text { circumstances. Regulation should require comprehensive } \\
\text { contingency planning for insurers and brokers. }\end{array}$ \\
\hline
\end{tabular}

\section{Recommendations and the Authorities' Responses}

\section{Annex Table 4. The Bahamas: Recommendations to Improve Observance of ICPs}

\begin{tabular}{|l|l|}
\hline \multicolumn{1}{|c|}{ Insurance Core Principle } & \multicolumn{1}{c|}{ Recommendations } \\
\hline $\begin{array}{l}\text { 1. Objectives, Powers and } \\
\text { Responsibilities of the Supervisor }\end{array}$ & $\begin{array}{l}\text { Attorney General consultations should only be reserved for } \\
\text { major regulatory changes. } \\
\text { To avoid gaps in regulatory authority, consideration should be } \\
\text { given to combining the Acts in the legislation. }\end{array}$ \\
\hline 2. Supervisor & $\begin{array}{l}\text { ICB Board members should serve staggered terms and } \\
\text { reasons for removal of Board members or Superintendent } \\
\text { should be published. This would help maintain continuity and } \\
\text { increase independence of the ICB. Substantial operational } \\
\text { authority should be delegated to the Superintendent to improve }\end{array}$ \\
\hline
\end{tabular}




\begin{tabular}{|c|c|}
\hline & efficiency and responsiveness of the ICB. \\
\hline $\begin{array}{l}\text { 3. Information Exchange and } \\
\text { Confidentiality Requirements }\end{array}$ & $\begin{array}{l}\text { It is recommended that the powers to obtain information should } \\
\text { be extended to relevant non regulated entities, in particular to } \\
\text { the holding company of the group. }\end{array}$ \\
\hline 4. Licensing & $\begin{array}{l}\text { It is recommended that ICB include time frames for license } \\
\text { application. }\end{array}$ \\
\hline 5. Suitability of Persons & $\begin{array}{l}\text { Modify statutory language to clarify the scope of fit and proper } \\
\text { review authority to all key management personnel and develop } \\
\text { a formal process for continuous monitoring of fit and proper } \\
\text { status of key personnel. }\end{array}$ \\
\hline $\begin{array}{l}\text { 6. Changes in Control and Portfolio } \\
\text { Transfers }\end{array}$ & $\begin{array}{l}\text { ICB should publish its capital assessment guidelines and create } \\
\text { an internal operational manual to identify the factors and } \\
\text { reasons supporting its prudential supervisory review processes } \\
\text { in capital adequacy evaluations. }\end{array}$ \\
\hline 7. Corporate Governance & $\begin{array}{l}\text { Develop corporate governance and risk management } \\
\text { standards, processes and procedures and conduct ad hoc } \\
\text { onsite reviews and examination tools. }\end{array}$ \\
\hline $\begin{array}{l}\text { 8. Risk Management and Internal } \\
\text { Controls }\end{array}$ & $\begin{array}{l}\text { Amend the regulations to impose an effective risk management } \\
\text { requirement and publish standards and best practices guidance } \\
\text { for development of a risk management program and } \\
\text { establishment of insurers' internal controls. }\end{array}$ \\
\hline $\begin{array}{l}\text { 9. Supervisory Review and } \\
\text { Reporting }\end{array}$ & $\begin{array}{l}\text { The full implementation of the } 3 \text { year plan towards an RBS is } \\
\text { strongly recommended, in particular onsite examinations } \\
\text { should be initiated without delay. }\end{array}$ \\
\hline $\begin{array}{l}\text { 10. Preventive and Corrective } \\
\text { Measures }\end{array}$ & $\begin{array}{l}\text { Improve ability to take timely preventive actions and establish } \\
\text { ladders of intervention authority. Going forward, ICB should } \\
\text { develop the fine and penalty process and develop and publish } \\
\text { standards and guidelines for the imposition of fines and } \\
\text { penalties to assure consistency and fairness in application. }\end{array}$ \\
\hline 11. Enforcement & $\begin{array}{l}\text { Develop and publish fine and penalty standards and guidelines } \\
\text { and maintain a schedule and parameters of potential sanctions } \\
\text { for particular offences. }\end{array}$ \\
\hline $\begin{array}{l}\text { 12. Winding-up and Exit from the } \\
\text { Market }\end{array}$ & $\begin{array}{l}\text { It is recommended to include life insurers under the voluntary } \\
\text { liquidation procedures valid for nonlife insurers. }\end{array}$ \\
\hline $\begin{array}{l}\text { 13. Reinsurance and Other Forms } \\
\text { of Risk Transfer }\end{array}$ & $\begin{array}{l}\text { Life insurers should be allowed to have reinsurance credit } \\
\text { under the same conditions as nonlife insurers. }\end{array}$ \\
\hline 14. Valuation & $\begin{array}{l}\text { It is strongly recommended to introduce a standard } \\
\text { methodology for the valuation of the long-term insurer liabilities } \\
\text { that should comply with the IAIS valuation principle } \\
\text { requirements, and a more sophisticated methodology for the } \\
\text { valuation of the liabilities for general insurers is recommended. }\end{array}$ \\
\hline 15. Investment & $\begin{array}{l}\text { It is recommended to draft and publish guidelines to spell out } \\
\text { the ICB expectations of a prudent person. } \\
\text { Considerations should be made to relax the limitations on the } \\
\text { amount that insurer could invest in foreign assets for the } \\
\text { improvement of diversification and asset liability matching } \\
\text { purposes. }\end{array}$ \\
\hline $\begin{array}{l}\text { 16. Enterprise Risk Management } \\
\text { for Solvency Purposes }\end{array}$ & $\begin{array}{l}\text { ICB should develop policies and practices for the oversight of } \\
\text { enterprise risk management for solvency purposes. }\end{array}$ \\
\hline 17. Capital Adequacy & Going forward it should be a high priority for the ICB to develop \\
\hline
\end{tabular}




\begin{tabular}{|c|c|}
\hline & $\begin{array}{l}\text { a risk-sensitive solvency framework. In the interim, similar to } \\
\text { Solvency I, the current calculation should include also a } \\
\text { reference factor to the claims paid and a liquidity test based on } \\
\text { the availability of liquid funds to pay the average of the last } \\
\text { three years claims in the case of general insurance. } \\
\text { A ladder of supervisory actions using the solvency levels } \\
\text { should be developed hand in hand with the introduction of the } \\
\text { risk sensitive solvency regime }\end{array}$ \\
\hline 18. Intermediaries & $\begin{array}{l}\text { ICB is recommended to consider removing the limitation on } \\
\text { board membership for brokers and agents and use fit and } \\
\text { proper requirements exclusively. } \\
\text { ICP should revise and update sales persons' licensing tests } \\
\text { and consider utilizing an independent testing entity. } \\
\text { ICB is recommended to amend legislation to specifically require } \\
\text { intermediaries to establish a premium payment trust account } \\
\text { separate from the intermediary's operating account. }\end{array}$ \\
\hline 19. Conduct of Business & $\begin{array}{l}\text { Further development of the ICB consumer protection } \\
\text { supervision is necessary following international best practice, } \\
\text { including establishing an ombudsman to provide for handling } \\
\text { claims disputes and providing advice to consumers. }\end{array}$ \\
\hline 20. Public Disclosure & $\begin{array}{l}\text { The ICB should require publication in the public registry of } \\
\text { insurer solvency position, claims, complaints, auditor } \\
\text { management statements, financial highlights, solvency ratios, } \\
\text { premium information and other highlights. }\end{array}$ \\
\hline 21. Countering Fraud in Insurance & $\begin{array}{l}\text { Amend regulation to add specific fraud oversight } \\
\text { responsibilities and enact quality immunity protections for ICB's } \\
\text { anti-fraud activity. }\end{array}$ \\
\hline $\begin{array}{l}\text { 22. Anti-Money Laundering and } \\
\text { Combating the Financing of } \\
\text { Terrorism }\end{array}$ & $\begin{array}{l}\text { Close collaboration with the Compliance Commission is } \\
\text { recommended for the next months to avoid supervisory gaps. }\end{array}$ \\
\hline 23. Group-wide Supervision & $\begin{array}{l}\text { Develop regulations for appropriate group supervision in } \\
\text { accordance with the ICP } 23 \text {. }\end{array}$ \\
\hline $\begin{array}{l}\text { 24. Macroprudential Surveillance } \\
\text { and Insurance Supervision }\end{array}$ & $\begin{array}{l}\text { Establish policies and processes for macroprudential } \\
\text { surveillance following the ICP } 24 \text { standards. }\end{array}$ \\
\hline $\begin{array}{l}\text { 25. Supervisory Cooperation and } \\
\text { Coordination }\end{array}$ & $\begin{array}{l}\text { The ICB should take steps to formalize the supervisory college } \\
\text { process by establishing best practices for key functions and } \\
\text { coordination mechanisms for establishing and leading } \\
\text { supervisory colleges while still maintaining flexibility in } \\
\text { supervisory college operation. }\end{array}$ \\
\hline $\begin{array}{l}\text { 26. Cross-border Cooperation and } \\
\text { Coordination on Crisis Management }\end{array}$ & $\begin{array}{l}\text { Regulation should require comprehensive contingency planning } \\
\text { for insurers and brokers and the ICB is recommended to start } \\
\text { the coordination of crisis management with relevant foreign } \\
\text { supervisors. }\end{array}$ \\
\hline
\end{tabular}




\section{E. Authorities' Response to the Assessment}

33. The ICB welcomes the detailed assessment of the observance of the IAIS Insurance Core Principles (ICPs) conducted by the IMF through the FSAP mission. The assessment has been particularly encouraging at a critical time where the acknowledgment of our accomplishments by the IMF validates the significant progress we have made in insurance supervision over the last three years. We consider the findings of the FSAP an important benchmark as we continue to develop a robust supervisory and regulatory framework consistent with international standards and best practices. The assessors have given specific commendation for the enactment of insurance legislation and the establishment of the ICB with qualified staff, authority and autonomy to provide effective supervision. Significant improvements in supervisory infrastructure and processes were also recognized as noteworthy achievements.

34. Many of the recommendations of the FSAP have already been under consideration by the ICB, and we have developed a plan to implement most of these initiatives over the near to medium term. Some of the others can readily be incorporated into our plan and we have prioritized these as appropriate, given our resources and ongoing work plan. Below we highlight our response to some of the more notable recommendations made in the report.

\section{Principles on the Supervisor and Cooperation (ICPs 1-3, 25-26)}

35. The majority of the recommendations made with respect to the captioned principles are already incorporated into the ICB's three year work plan and we will continue our efforts to formalize our internal processes, develop guidelines and improve our systems. We continue to strengthen our relationship with our local and regional regulators and have been recently elected to position of Vice-President of the Caribbean Association of Insurance Regulators, a position which we will use to steer the progress toward even greater cooperation and information sharing among regional regulators. Furthermore, we are currently reviewing a draft MOU with a fellow regulator in the region and we intend to enter into MOUs with home regulators of our major foreign insurers over the next eighteen months. With the assistance of the Toronto Centre, and in cooperation with the Central Bank and the Securities Commission we are embarking on a programme to develop our Crisis Management framework. The first phase of this initiative will be completed in November 2012. It is intended that at the conclusion of that programme all regulators will agree on a Crisis Management protocol and develop consistent frameworks.

\section{Principles on Operational Requirements (ICPs 4-8)}

36. Our three year plan addresses all the areas noted under the captioned ICP's, namely licensing, change in control, corporate governance, risk management and internal controls. We will develop comprehensive best practices for the industry in the near and medium term. In the interim, we have drafted assessment criteria for corporate governance and risk 
management that incorporate best practices including roles and responsibilities, performance and risk indicators for key risk management functions. These will be released for industry consultation January 2013 along with the Risk Based Supervision Methodology and Framework and the Ladders of Supervisory Intervention. Additionally, we have carried out ad hoc onsite examinations addressing various aspects of corporate governance. We have now commenced a more integrated onsite examination programme which is consistent with our supervisory framework.

\section{Principles on Supervisory Practices (ICPs 9-12, 23-24)}

37. We continue to implement our Risked Based Supervision Framework, incorporating enhanced off site monitoring and focused on site examinations. As noted above, we intend to consult with the industry early in 2013 on the framework, Ladders of Intervention and the Risk Assessment Criteria. Much of the planning and preparation for our onsite examinations have been completed and two examinations are scheduled for early September 2012. Our legislation grants us the authority to conduct onsite examinations as often as needed and we are not required to give notice to the insurer, but will do so as appropriate. Further, the ICB may require the production of any information from an insurer and other related parties even where such activities are outsourced.

38. With respect to group wide supervision, we will incorporate consolidated supervision measures into our Risk Based Supervision Framework to ensure that those entities which are part of groups are effectively supervised on a consolidated basis. Additionally, we will continue to participate and become more proactive as appropriate in local and regional colleges of regulators for the supervision of group entities.

39. We acknowledge that there is work to be done in the area of macro prudential supervision and we anticipate that with the implementation and continued development of our quarterly reporting system we will further enhance our capabilities in this area. Further, the ICB has undertaken horizontal / cross-system reviews in a number of key areas over the last few years including, but not limited to actuarial valuations, early warning indicators, reinsurance and solvency. The ICB has required life insurers to perform stress testing and will also review these on a cross sector basis. Additionally, following our onsite examination for investments and investment management processes we will undertake a horizontal review and develop best practice guidelines.

\section{Principles on Prudential Requirements (13-22)}

40. The ICB is committed to the development of a Risk Based Capital Framework in the medium term. We believe that the Risk Based Supervision Framework is a first step in that direction because it facilities the assessment of capital adequacy based on the risk profile of the insurance company. However, we note your recommendations for interim measures to 
modify the capital test to adopt a total balance sheet approach. These recommendations will be built into our supervisory plans for the very near term.

41. Other areas such as investments, valuation, intermediaries, market conduct, and fraud are a priority for the ICB and a number of initiatives have been scheduled to address these areas. The recommendations noted will be incorporated to the extent appropriate for our market.

42. On the matter of valuing investments for solvency purposes, it must be noted that investment instruments are not rated in our market. As such, the Commission has evaluated the credit quality and liquidity of categories of instruments based on knowledge of the market and the discount rates applied to the category are published in the Regulations. This area has been reviewed and discussed with industry participants and changes were adopted following these consultations. Also, while we agree that the current exchange control requirements limit insurers' ability to diversify their portfolio and match their long-term liabilities, any relaxations to exchange controls will have to be considered by the Government, as the exchange control regime is a crucial part of The Bahamas' economic stability. However, the ICB will engage in dialogue with the Government regarding this recommendation.

43. Since taking over the AML functions from the Compliance Commission of The Bahamas (CCB) in 2010 our staff has undergone a number of training activities hosted by the $\mathrm{CCB}$. In addition, we continue to work closely with the $\mathrm{CCB}$ and leverage the expertise of its staff. It should be noted that while the law does not require general insurers to undergo an AML examination and implement AML systems, the ICB has encouraged general insurers to implement such systems to the extent appropriate given their associated risks.

44. Finally, the assessment has affirmed our plans and our progress. We have taken note of the recommendations and the ICB has an aggressive agenda for continued development of our supervisory and regulatory regime and compliance with the IAIS ICPs. ICB is committed to completing the implementation of our Risk Based Supervisory Framework, to formalizing and publishing our supervisory processes, to the ongoing development of policies, guidelines and other best practices, to promoting fair market conduct, and generally to continuing to enhance our people, processes and systems. 


\section{ANNEX III. IMPLEMENTATION OF THE IOSCO ObJeCtives AND PRINCIPLES OF SECURITIES REgULATION}

\section{Compliance with the International Organization of Securities Commissions} (IOSCO) Principles is generally high, although some weaknesses need to be resolved. The new SIA has dealt effectively with most of the issues identified in the 2004 assessment. It has reinforced the powers of the SCB to supervise the securities markets and firms and individuals carrying on securities business and to impose effective sanctions in the event of a breach of the law, regulations and rules made under it. The SIA has secured the independence of the SCB from Government although issues concerning the stability of Government funding remain. These are being addressed. The SCB is better resourced in terms of numbers of professional staff and technical facilities. The full impact of the SIA on licensees and public issuers will only begin to become apparent towards the end of 2012 and into 2013.

46. Regulation of the investment funds industry has not kept pace with regulatory developments globally. The current governing legislation, the IFA, does not provide sufficiently for the SCB, as the regulator of investment funds, to set mandatory standards for the management of the assets of a fund and their protection as is now current good practice. The need to update the IFA is recognized by the Government, the SCB and the industry and initial consultations are underway. Although amendment to the Act is necessary, the SCB could take a more proactive stance by expanding the scope of its inspections beyond the current focus on fund administrators, to cover those fund managers, operators and custodians with a physical presence in the jurisdiction.

47. The SIA provides an effective framework to enable the sharing of information and cooperation between the SCB and other regulators, domestic and foreign on supervisory and enforcement matters. Recent amendments to the SIA at the request of IOSCO are intended to enable the SCB to become a full signatory to the IOSCO MMoU. The SCB (and the Office of the Attorney General in criminal matters) have dedicated resources to responding in a timely and effective fashion to requests for information from overseas regulators and appear strongly committed to playing a full part in measures to detect and prosecute cross border abusive and criminal conduct.

\section{INTRODUCTION}

48. An assessment of the level of implementation of the IOSCO Principles in The Bahamas was conducted during July, 2012 as part of the Financial Sector Assessment Program. An initial IOSCO assessment was conducted in 2002. At that time several weaknesses in the scope and effectiveness of securities market regulation were identified. Since then The Bahamas has gone through a process of updating the key legislative Acts 
governing the provision of financial services. The SCB has also grown in size and responsibilities and has adopted more intensive and focused supervision of licensees.

\section{INFORMATION AND METHODOLOGY USED FOR ASSESSMENT}

\section{The assessment was conducted based primarily on the IOSCO Principles and} Objectives of Securities Regulation 2003 and the Assessment Methodology as updated in 2011. The disparity arose because the FSAP commenced prior to the date at which assessment against the new Principles became mandatory. It was agreed with the authorities that the benchmarked assessment would be based on the original 30 Principles and not the new 38. In practice, the SCB prepared an extensive self-assessment based on the 38 Principles and the new Methodology which included detailed descriptions of the legal basis for the exercise of the SCB's powers. Compliance with the new Principles was not however benchmarked.

50. The IOSCO methodology requires that assessors not only look at the legal and regulatory framework in place, but also at how it has been implemented in practice. The ongoing global financial crisis has reinforced the need for assessors to take a critical look at, and to make a judgment on, supervisory practices and to determine whether they are sufficiently effective. Among other exercises, such a judgment involves a review of the inspection programs for different types of supervised entities, the cycle, scope and quality of inspections as well an assessment of how the agency follows up on findings, including by using enforcement actions. This entails extensive discussions with the staff of the regulator when were extremely helpful, frank, and cooperative.

\section{REgulatory STRUCTURE}

51. The SCB is the sole regulator responsible for the administration of the securities laws. These laws are the SIA which replaced its 1999 predecessor in December 2011; and the IFA. It is also responsible for the operation of the Financial and Corporate Service Providers Act, 2000 (FCSPA) but this role was not part of the assessment. It thereby supervises and regulates the activities of the securities and capital markets and firms and individuals carrying on securities business as defined, investment funds, investment fund administrators, and corporate and financial service providers (the latter provide financial services for which a license under the banking, securities and insurance laws is not required). The components of the SCB's mandate include the formulation of principles to regulate and govern investment funds, securities and capital markets; the maintenance of surveillance over the sector, ensuring orderly, fair and equitable dealings; creating and promoting conditions to ensure orderly growth and development; recommending regulations to the Minister and formulating rules. In executing its mandate, the SCB issues regulatory tools, rules guidance etc. to facilitate the authorization of licensees, and their compliance with ongoing supervisory requirements. 


\section{Legal Framework}

52. The three principal laws from which the SCB derives its powers are the SIA, the IFA and the FCSPA. The SIA was brought into force on December 30, 2011. Subsequently, the Securities Industry Regulations (SIR) were also promulgated, effective January 9, 2012. This was the end result of an extended process (including public consultation) following recommendations by a technical assistance mission by the IMF in 2004 and the engagement of a consultant by the Caribbean Regional Technical Assistance Centre (CARTAC) to draft a new Act (and Regulations) to replace the 2009 Securities Industry Act and Regulations. Objectives included addressing the recommendations and becoming consistent with international best practice as codified by the IOSCO Objectives and Principles of Securities Regulation taking account of the size, scope and development of the securities markets in The Bahamas.

\section{Work has begun on updating the IFA and its associated regulations with the} same objectives. As an initial step, the provisions of the SIA that apply generally to the SCB and its powers to supervise the securities markets and their participants have been applied via provisions of the SIA to investment funds, fund administrators and fund managers. These include all the provisions on investigations, inspections and enforcement and the provision of assistance to other regulators. Although many requirements of the new Act became operational immediately, some changes were subject to transition periods of 6 or 12 months. The Act will become fully effective on December 31, 2012.

\section{Investment activities and services to clients and dealing for own account can be} carried on by banks (subsidiarization is not required), non-bank investment firms and insurance companies. The SCB licenses and regulates non-bank investment firms, banks, investment funds (collective investment schemes), investment fund administrators, BISX (the only stock exchange in The Bahamas) and clearing and settlement facilities for business carried on under the SIA and IFA. The CBoB licenses banks and supervises them from a prudential perspective. The Insurance Commission licenses insurance companies and supervises them from a prudential perspective. The SCB licenses and supervises banks and insurance companies for their conduct of investment services and activities. In licensing and supervising clearing and settlement facilities this function is shared with the $\mathrm{CBoB}$, which is responsible for designating and supervising the payment system. Currently, there is no explicit legal underpinning of the CBoB's oversight power over the securities settlement system. Prospectuses for new issues of securities must be approved by the SCB which also supervises and grants approval to takeover bids using its powers under the SIA. The SCB has an extensive range of sanctions available to it to deal with violations. Auditors are licensed by their professional body, The BICA under the Public Accountants Act 1991 and must be approved by the SCB in order to audit public issuers, firms licensed under the SIA and IFA, and exchanges and clearing facilities. 


\section{MARKet Structure}

\section{A. Market Intermediaries}

55. At end-2011, there were 132 licensees under the SIA 1999 (now repealed), up 13.8 percent year-on-year. Of the 18 "full service" broker dealer licensees, 11 are bank and trust companies. 65 entities are licensed for dealing in securities, arranging deals in securities, managing securities and advising on securities. Under the SIA 1999, the boundaries between types of license were not sufficiently clear cut. This has been corrected in the new SIA and new function-based licenses are in the process of being issued to applicants and existing licensees.

56. ${ }^{1}$ Data on securities business done with Bahamians in the Bahamas is presently not tracked, nor the degree of business conducted with clients outside of the jurisdiction.

\section{B. Collective Investment Schemes}

57. At end 2011 there were $\mathbf{7 1 3}$ investment funds licensed by or registered with the SCB; Total funds under management were B\$ 86.81 billion. Overall the number of investment funds has declined significantly particularly for Recognized Foreign Funds (RFF); the exception is the Specific Mandate Alternative Regulatory Test Fund (SMART) fund category. The SMART fund structure was enabled in 2003 following passage of the IFA. The SCB has to approve the regulatory and operational mandate of a fund as set up by the operator to address the particular risks associated with that fund. There are no money market funds. The SCB has not defined a category of investment funds as hedge funds. Resident and non-resident ownership of investment funds is not tracked. A foreign fund is recognized (and registered as such by the SCB), if it has a nexus in The Bahamas (e.g., it is incorporated in the jurisdiction) and it is either listed on an overseas exchange prescribed by the SCB or licensed or registered in a jurisdiction which, in the view of the SCB provides equivalent regulation of funds. Currently, all RFFs are registered in the United States.

58. There are only three fund managers (that is entities responsible for making investment decisions and executing orders on behalf of the fund) located in The Bahamas. They manage twelve funds. The main business in The Bahamas is fund administration, with 65 firms being licensed to carry out this business (a range of functions intended to ensure that the operation of the investment fund are carried out in accordance with the investment fund's offering memorandum and constitutive documents and the regulations to the exclusive interest of the investors).

\footnotetext{
${ }^{1}$ This accounts for the discrepancy in numbers and types of licenses.
} 


\section{Markets}

59. Securities trading is extremely thin and has been declining since 2008. Exchange control regulations have restricted the scope of the BISX largely to domestic issuers and domestic investors. According to BISX, the retail investor base is no more than 20,000 (the population in The Bahamas is 345,000 ), and the maximum number of potentially active investors is no more than 5,000. BISX lists 25 securities, 19 common shares, 2 preference shares, and 4 debt issues. It also lists 20 investment funds. BISX is 46 percent owned by the Government of The Bahamas and has 5 broker-dealer members In The Bahamas all transactions in BISX listed securities must be put through the exchange. Average daily trading volume in 2011 was 11,451 shares; and average daily trading value was B\$59,674. The benchmark BISX All-Share Index decreased by 8.9 percent in 2011 extending 2010's 4.2 percent decline and 2009's decline of 8.58 percent. In 2011 market capitalization fell by one percent to B $\$ 2.875$ billion. Six of the 19 equity issuers are banks. One bank, First Caribbean Bank, accounts for 40 percent of market capitalization. The shares of five companies trade in the over-the-counter (OTC) market. There is also an active private placement market for preference shares, including perpetuals (preference shares with no end date), estimated at B \$15-20 million per annum and a similar bilaterally negotiated market for commercial paper out to one year maturity.

\section{Preconditions For EfFective Securities Regulations}

\section{The Bahamas is a stable democracy with an independent judiciary and a legal} system based on English common law principles. Court judgments are decided primarily by precedents set by previous cases. It has well qualified and professional legal and accountancy professionals and in the case of the latter requires them to use and comply with the global standards for accounting and auditing, IFRS and International Standards on Auditing (ISA) although enforcement appears weak. There has been extensive case law developed on directors' liabilities in recent years. The impact of bankruptcy law on the protection of segregated client assets in the event of a bankruptcy of a licensed firm or custodian is untested. The SCB has published for consultation a Code of Corporate Governance based on the Organization for Economic Cooperation and Development (OECD) Principles. The $\mathrm{CBoB}$ has already established Corporate Governance Guidelines for banks. The State encourages new entrants to its securities and investment fund industries, is committed to meeting internationally recognized standards of regulation in banking, securities and insurance and seeks to ensure that regulatory costs are proportionate are fairly distributed.

\section{MAIn Findings}

61. Principles relating to the regulator: The SCB has sole responsibility for regulation of securities markets and the investment fund industry in The Bahamas. Banks are able to carry on investment business without subsidiarization on the basis of a license issued by the 
SCB. SCB will take into account the views of the $\mathrm{CBoB}$ when considering an application but the decision to grant or reject is for the SCB alone. As a matter of administrative policy the SCB permits banks with securities licenses to operate under the regulatory capital rules of the $\mathrm{CBoB}$. This approach is supported by cooperative arrangements between the $\mathrm{SCB}$ and the $\mathrm{CBoB}$ including the carrying out of joint inspections. Cooperation and communication is further facilitated via the GFSR which comprises the $\mathrm{CBoB}$, the SCB, the Inspector of Financial and Corporate Services (the functions of which are carried out by the SCB), the ICB and the Compliance Commission. The SCB is independent of Government under the law, although its current reliance to a considerable degree on government funding has resulted in some volatility in income. This is being addressed. The SCB has a wide set of powers, in the use of which it is properly accountable. In order to translate the powers given to it under the SIA into a practical regulatory methodology and to improve standards among securities market participants and public issuers, the SCB is undertaking a very extensive and demanding program of public consultation on numerous initiatives. The SCB is at an early stage in developing an approach to deal with systemic risk and is participating in the work of the $\mathrm{CBoB}$ in this area. No organization has formal Self Regulatory Organization (SRO) status in The Bahamas. The BISX is licensed by and subject to the oversight of the SCB.

62. Principles for the enforcement of securities regulation: The SCB has broad powers of inspection, investigation and surveillance under the SIA. These sections of the SIA, which came into force in December 2011, also apply to licensees under the IFA. The equivalent sections of the IFA and the Investment Funds Regulations 2003 (IFR) have been disapplied. The SCB's administrative and civil powers and sanctions as set out in the SIA are effective, proportionate and dissuasive. Weaknesses exist in the supervision of participants in the investment funds sector.

63. Principles for cooperation in regulation: The SIA gives the SCB broad authority to exercise its powers to assist both domestic and foreign regulatory authorities in the performance of their regulatory functions. The SCB appears able and willing to offer effective and timely assistance to foreign regulators in obtaining information and in responding to other requests based on its internal organization and its stated commitment to prioritize requests for information from foreign regulators. It is currently (October 2012) a Blist signatory to the MMoU but expects to become an A-list signatory in December 2012.

64. Principles for issuers: The imposition of the draft Takeover Code by the SCB, as enabled by the SIA, will close a significant gap in corporate legislation in The Bahamas while the introduction and enforcement of the Corporate Governance Code by the SCB should make a positive contribution to shareholder rights and increase the awareness of directors as to their duties and liabilities. IFRS are used unmodified and de facto are updated as the International Accounting Standards Board (IASB) produces changes without the need for intervention by the accountants' professional body, BICA. 


\section{Principles for auditors, credit rating agencies and other information service}

providers: These principles were not benchmarked. As regards auditors, while they are required to adhere to the standards of the international standard setting body International Federation of Accountants (IFAC), there is no body acting in the public interest which oversees the work of auditors or their professional body, BICA. There is no peer preview process (though BICA has one in the planning stage) and BICA's powers to discipline its members are limited. As regards credit rating agencies, banks are able to use external ratings when calculating capital charges under the CBoB's market and credit risk rules; SCB proposes to permit their use by non-banks in the Specific Risk Factor of the Market Risk Requirement as set out in its draft regulatory capital rule. However, no Credit Rating Agencies (CRAs) are located in The Bahamas. As regards other information service providers there are only very limited analytical or evaluative services offered to investors and the current level of oversight is probably appropriate.

66. Principles for collective investment schemes: The current governing Act, the IFA, which was introduced in 2003, is no longer sufficient to match good practice as set out in the IOSCO Principles. It does not give the SCB sufficient powers to mandate certain actions and to encourage high standards among managers, operators and custodians as has become the norm. However, under the existing law the SCB could be more proactive in supervising those fund managers, operators and custodians that are located in The Bahamas.

67. Principles for market intermediaries: The SIA provides a function-based approach to licensing which removes the ambiguities in the previous Act as to which activities a firm was legally able to carry on under a particular class of license. The draft regulatory capital rule will bring consistency of treatment between banks and non-banks licensed to carry on securities business. Periodic on-site examinations appear to be comprehensive, tailored to match the business models of particular categories of licensees and require the exercise of judgment by examiners. The SCB has begun to develop a risk based approach to prioritize its inspection program.

\section{Principles for secondary markets: The securities market is small, non-complex,} and illiquid. Short selling does not appear to take place. Settlement of securities takes place at the Bahamas Central Securities Depository, which is the register of listed corporate shares, in a dematerialized manner, while settlement of funds is achieved bilaterally by brokers providing cheques in the offices of BISX. The SCB has adequate powers over the exchange and the licensing process appears comprehensive and sufficient. The transparency of trading on BISX should be improved. While the number of cases of market manipulation and similar abuses are very low there appears to be no reluctance on the part of the SCB to take administrative action or on the part of the Office of the Attorney General to take criminal action when wrong-doing is suspected. 


\section{Annex Table 5. The Bahamas: Summary Implementation of the IOSCO Principles}

\begin{tabular}{|c|c|}
\hline Principle & Findings \\
\hline $\begin{array}{l}\text { Principle } 1 . \text { The responsibilities of the } \\
\text { Regulator should be clear and objectively } \\
\text { stated. }\end{array}$ & $\begin{array}{l}\text { The responsibilities and purposes of the SCB are clearly } \\
\text { set out in the relevant Acts and there do not appear to be } \\
\text { any gaps. Cooperation between the SCB, the CBoB and } \\
\text { the Insurance SCB appears to be good at a senior level } \\
\text { (in the GFSR) and at an operational level, as in the joint } \\
\text { inspection program operated by the SCB and the CBoB } \\
\text { for dually licensed banks. Products with equity type } \\
\text { features are not offered by banks and insurance } \\
\text { intermediaries. }\end{array}$ \\
\hline $\begin{array}{l}\text { Principle 2. The Regulator should be } \\
\text { operationally independent and accountable } \\
\text { in the exercise of its functions and powers. }\end{array}$ & $\begin{array}{l}\text { The volatility of the government subvention to provide } \\
\text { operating funds for the SCB in } 2010-12 \text { is of concern. } \\
\text { Going forward the decision to empower the SCB to raise } \\
\text { more fees from its licensees should contribute to a pattern } \\
\text { of more stable funding. } \\
\text { The new SIA has remedied the problem of the old law } \\
\text { regarding the operational independence of the SCB from } \\
\text { Government while ensuring that it remains properly and } \\
\text { publicly accountable for its performance. }\end{array}$ \\
\hline $\begin{array}{l}\text { Principle } 3 . \text { The Regulator should have } \\
\text { adequate powers, proper resources and } \\
\text { the capacity to perform its functions and } \\
\text { exercise its powers. }\end{array}$ & $\begin{array}{l}\text { There do not appear to be any obvious weaknesses as } \\
\text { regards powers, resources and capacity. Head count rose } \\
\text { by } 18 \text { percent in the last two years and staff are well- } \\
\text { qualified and appear to be well-motivated. }\end{array}$ \\
\hline $\begin{array}{l}\text { Principle } 4 . \text { The Regulator should adopt } \\
\text { clear and consistent regulatory processes. }\end{array}$ & $\begin{array}{l}\text { The implementation by the SCB of its obligations under } \\
\text { the SIA appears considered, comprehensive and } \\
\text { transparent. }\end{array}$ \\
\hline $\begin{array}{l}\text { Principle } 5 . \text { The staff of the Regulator } \\
\text { should observe the highest professional } \\
\text { standards, including appropriate standards } \\
\text { of confidentiality. }\end{array}$ & $\begin{array}{l}\text { There are no apparent gaps in the SCB's internal } \\
\text { processes to ensure that staff observe the highest } \\
\text { professional standards including appropriate standards of } \\
\text { confidentiality. }\end{array}$ \\
\hline $\begin{array}{l}\text { Principle } 6 \text {. The Regulator should have or } \\
\text { contribute to a process to monitor, mitigate } \\
\text { and manage systemic risk, appropriate to } \\
\text { its mandate. }\end{array}$ & $\begin{array}{l}\text { New Principle-not benchmarked. The SCB is at an early } \\
\text { stage in developing an approach to deal with systemic } \\
\text { risk. It is participating in the work of the CBoB in this area. } \\
\text { The GFSR appears to provide an effective forum for } \\
\text { discussing issues concerning systemic risk between } \\
\text { sectoral regulators at a senior management level. }\end{array}$ \\
\hline $\begin{array}{l}\text { Principle } 7 . \text { The Regulator should have or } \\
\text { contribute to a process to review the } \\
\text { perimeter of regulation regularly. }\end{array}$ & $\begin{array}{l}\text { New Principle-not benchmarked. The recently } \\
\text { established New Projects / Service Evaluation Committee } \\
\text { appears to be organized and staffed in a way which will } \\
\text { make a more coherent and comprehensive contribution to } \\
\text { perimeter matters than the previous ad hoc } \\
\text { arrangements. }\end{array}$ \\
\hline
\end{tabular}




\begin{abstract}
Principle 8. The Regulator should seek to ensure that conflicts of interest and misalignment of incentives are avoided, eliminated, disclosed or otherwise managed.
\end{abstract}

Principle 9. Where the regulatory system makes use of SROs that exercise some direct oversight responsibility for their respective areas of competence, such SROs should be subject to the oversight of the Regulator and should observe standards of fairness and confidentiality when exercising powers and delegated responsibilities.

Principle 10. The Regulator should have comprehensive inspection, investigation and surveillance powers.

Principle 11. The Regulator should have comprehensive enforcement powers.

Principle 12. The regulatory system should ensure an effective and credible use of inspection, investigation, surveillance and enforcement powers and implementation of an effective compliance program.

Principle 13. The Regulator should have authority to share both public and non-public information with domestic and foreign counterparts.

Principle 14. Regulators should establish information sharing mechanisms that set out when and how they will share both public and non-public information with their domestic and foreign counterparts.
New principle—not benchmarked. The SIA and SIR provide for a sufficient regulatory framework within which SCB can exercise appropriate supervisory powers to seek to ensure that satisfactory outcomes are achieved as regards conflicts of interest among licensees under the SIA and the IFA.

No organization has formal SRO status in The Bahamas. The BISX performs certain functions which have certain public interest elements embedded in them in respect of the operation of the securities market, continuous disclosure by listed companies and the clearing and settlement process. BISX is licensed by and subject to the oversight of the SCB. There is no independent director on the BISX board.

The SCB has the broad powers of inspection, investigation and surveillance under the SIA required by this Principle. These sections of the SIA, which came into force in December 2011, also apply to licensees under the IFA. The equivalent sections of the IFA and the IFR have been disapplied.

The SCB's administrative powers and sanctions as set out in the SIA are effective, proportionate and dissuasive.

In the securities market sector the SCB makes effective use of its extensive powers under the SIA. Licensees under the SIA and the IFA are required to have effective compliance programs and on-site and off-site monitoring is comprehensive and requires examiners to exercise judgment. However, within the investment funds sector, which is significantly larger than the securities market sector, only funds and the fund administrators are licensed. The SCB does not subject managers/advisers, operators or custodians to the level of ongoing oversight (including on-site examinations) it applies to investment fund administrators.

The SIA gives the SCB broad authority to exercise its powers to assist both domestic and foreign regulatory authorities in the performance of their regulatory functions.

Unless the screening group of IOSCO determines that, despite the recent legislative changes intended to achieve compliance, the SCB has not satisfied the criteria to become a full signatory to the MMoU and the reasons impact negatively on this assessment, it appears that the SCB and the legislative framework in The Bahamas merit a fully implemented rating. 


\begin{tabular}{|c|c|}
\hline $\begin{array}{l}\text { Principle 15. The regulatory system should } \\
\text { allow for assistance to be provided to } \\
\text { foreign Regulators who need to make } \\
\text { inquiries in the discharge of their functions } \\
\text { and exercise of their powers. }\end{array}$ & $\begin{array}{l}\text { It appears that the SCB is able and willing to offer } \\
\text { effective and timely assistance to foreign regulators in } \\
\text { obtaining the various types of information and other } \\
\text { requests for assistance set out in the Principle. }\end{array}$ \\
\hline $\begin{array}{l}\text { Principle 16. There should be full, accurate } \\
\text { and timely disclosure of financial results, } \\
\text { risk and other information that is material to } \\
\text { investors' decisions. }\end{array}$ & $\begin{array}{l}\text { The Bahamas legislation sets out in comprehensive detail } \\
\text { what information is to be provided and when and to } \\
\text { whom, prescribed notifications are to be made. The } \\
\text { timeliness of these requirements is also set out } \\
\text { appropriately and is consistent with international/IOSCO } \\
\text { standards. }\end{array}$ \\
\hline $\begin{array}{l}\text { Principle 17. Holders of securities in a } \\
\text { company should be treated in a fair and } \\
\text { equitable manner. }\end{array}$ & $\begin{array}{l}\text { As of October 2012, there is no regulation of takeovers } \\
\text { although the SIA has set out an enabling provision with } \\
\text { the SCB as the regulator. Corporate governance } \\
\text { standards are also weak. These deficiencies will be } \\
\text { addressed when the takeover and corporate governance } \\
\text { codes are implemented. }\end{array}$ \\
\hline $\begin{array}{l}\text { Principle 18. Accounting standards used by } \\
\text { issuers to prepare financial statements } \\
\text { should be of a high and internationally } \\
\text { acceptable quality. }\end{array}$ & $\begin{array}{l}\text { IFRS are used unmodified and de facto are updated as } \\
\text { the IASB produces changes without the need for } \\
\text { intervention by the accountants' professional body, BICA. } \\
\text { BICA does not, apparently, provide interpretations of } \\
\text { IFRS. BICA is not required to work cooperatively with, or } \\
\text { be subject to oversight by, the SCB or another body that } \\
\text { acts in the public interest as is required by the Principle. }\end{array}$ \\
\hline $\begin{array}{l}\text { Principle 19. Auditors should be subject to } \\
\text { adequate levels of oversight. }\end{array}$ & $\begin{array}{l}\text { New principle - not benchmarked. The explanatory notes } \\
\text { to this Principle, while recognizing that structures may } \\
\text { differ between jurisdictions, stresses that "the auditor } \\
\text { oversight framework should not be based exclusively or } \\
\text { predominantly on self-regulation." Unfortunately that is the } \\
\text { position in The Bahamas. The SCB appears to be } \\
\text { stretching the use of its limited powers in this area as far } \\
\text { as it can but that is not sufficient. }\end{array}$ \\
\hline $\begin{array}{l}\text { Principle } 20 \text {. Auditors should be } \\
\text { independent of the issuing entity that they } \\
\text { audit. }\end{array}$ & $\begin{array}{l}\text { New principle-not benchmarked. Auditors are required } \\
\text { by the SIA to comply with the IFAC International Code of } \\
\text { Ethics for Professional Accountants. This is helpful but } \\
\text { not sufficient. There are no rotation requirements on } \\
\text { auditors. BICA does not conduct peer review analysis of } \\
\text { the work of its members but does respond to complaints. }\end{array}$ \\
\hline $\begin{array}{l}\text { Principle } 21 \text {. Audit standards should be of a } \\
\text { high and internationally acceptable quality. }\end{array}$ & $\begin{array}{l}\text { New Principle-not benchmarked. Auditing standards are } \\
\text { high as a result of the requirement that auditors comply } \\
\text { with the ISA issued by IFAC through the International } \\
\text { Auditing and Assurance Standards Board (IAASB). The } \\
\text { enforcement mechanism is not adequate. }\end{array}$ \\
\hline
\end{tabular}




\begin{abstract}
Principle 22. Credit rating agencies should be subject to adequate levels of oversight. The regulatory system should ensure that credit rating agencies whose ratings are used for regulatory purposes are subject to registration and ongoing supervision.
\end{abstract}

Principle 23. Other entities that offer investors analytical or evaluative services should be subject to oversight and regulation appropriate to the impact their activities have on the market or the degree to which the regulatory system relies on them.

Principle 24. The regulatory system should set standards for the eligibility, governance, organization and operational conduct of those who wish to market or operate a collective investment scheme.

Principle 25. The regulatory system should provide for rules governing the legal form and structure of collective investment schemes and the segregation and protection of client assets.

Principle 26. Regulation should require disclosure, as set forth under the principles for issuers, which is necessary to evaluate the suitability of a collective investment scheme for a particular investor and the value of the investor's interest in the scheme.

Principle 27. Regulation should ensure that there is a proper and disclosed basis for asset valuation and the pricing and the redemption of units in a collective investment scheme.
New principle—not benchmarked. Banks may use external ratings when calculating market and credit risk under the CBoB's market and credit risk rules; No CRAs are present in The Bahamas and the SCB does not have a regime for licensing and ongoing supervision of CRAs. It has not made a reasonable judgment that the CRAs whose ratings are permitted for use are subject to registration and oversight.

New principle-not benchmarked. At the current stage of development of the securities market the present high level approach of the SCB is probably sufficient. The level of granularity contemplated by IOSCO and as set out in the key questions to this Principle is lacking.

There are several deficiencies in the IFA and SIA and their enforcement by the SCB. Although shares or units of investment funds are defined as securities, there is a licensing exemption when a person deals in (i.e., sells or markets) only such securities. Only funds and the fund administrators are licensed and only the fund administrator, but not the, operator, manager or other related parties, is subject to a full assessment of its governance, organization and operational conduct. The SCB has begun work, in consultation with the investment funds industry, on a project to update the IFA and IFR to a level which meets the standards of regulation of investment funds as currently established by IOSCO.

There are no specific requirements in the IFA concerning the segregation of client assets and the operational conduct of the custodian. In the event of losses or insolvency of the investment fund operator the absence of specific requirements for the segregation of client assets is likely to be problematic.

The IFA is a disclosure based Act. As such it is effective in mandating that the information required by this Principle is provided to investors and potential investors. Some requirements do not set out that information has to comply with the level of specificity as required by IOSCO.

The current IFA and IFR do not meet the IOSCO requirements that the regulatory framework imposes obligations on fund managers, operators and administrators to act in certain ways as regards valuation, pricing and redemption. 


\begin{tabular}{|c|c|}
\hline $\begin{array}{l}\text { Principle 28. Regulation should ensure that } \\
\text { hedge funds and/or hedge funds } \\
\text { managers/advisers are subject to } \\
\text { appropriate oversight. }\end{array}$ & $\begin{array}{l}\text { New Principle-not benchmarked. While hedge funds fall } \\
\text { within the definition of investment funds under the IFA } \\
\text { and are regulated accordingly, the SCB has not } \\
\text { developed an oversight regime which seeks to define } \\
\text { specific funds or specific categories of funds as hedge } \\
\text { funds. It has not established whether any domestic funds } \\
\text { would meet the broad and unquantified indicators for } \\
\text { being considered a hedge fund such as "high risk," "highly } \\
\text { leveraged" "potentially systemically significant" as used by } \\
\text { IOSCO in the assessment methodology. }\end{array}$ \\
\hline $\begin{array}{l}\text { Principle 29. Regulation should provide for } \\
\text { minimum entry standards for market } \\
\text { intermediaries. }\end{array}$ & $\begin{array}{l}\text { The SIA provides a function-based approach to licensing } \\
\text { which removes the ambiguities in the previous Act as to } \\
\text { which activities a firm was legally able to carry on under a } \\
\text { particular class of license and the related entry criteria. }\end{array}$ \\
\hline $\begin{array}{l}\text { Principle } 30 \text {. There should be initial and } \\
\text { ongoing capital and other prudential } \\
\text { requirements for market intermediaries that } \\
\text { reflect the risks that the intermediaries } \\
\text { undertake. }\end{array}$ & $\begin{array}{l}\text { Although the current regulatory capital does not meet the } \\
\text { IOSCO requirements in several ways, this deficiency will } \\
\text { be addressed when the new regulatory capital rule is } \\
\text { introduced. It is intended that this will be a version of } \\
\text { Basel II based on the requirements of the CBoB for } \\
\text { banks. }\end{array}$ \\
\hline $\begin{array}{l}\text { Principle 31. Market intermediaries should } \\
\text { be required to establish an internal function } \\
\text { that delivers compliance with standards for } \\
\text { internal organization and operational } \\
\text { conduct, with the aim of protecting the } \\
\text { interests of clients and their assets and } \\
\text { ensuring proper management of risk, } \\
\text { through which management of the } \\
\text { intermediary accepts primary responsibility } \\
\text { for these matters. }\end{array}$ & $\begin{array}{l}\text { Periodic on-site examinations of securities market } \\
\text { licensees are carried out according to a detailed } \\
\text { Inspections Procedures Manual and Inspection Program } \\
\text { Questionnaire. Examinations appear to be } \\
\text { comprehensive, tailored to match the business models of } \\
\text { particular categories of licensees and require the exercise } \\
\text { of judgment by examiners. The SCB has begun to } \\
\text { develop a risk based approach to prioritize its inspection } \\
\text { program }\end{array}$ \\
\hline $\begin{array}{l}\text { Principle } 32 . \text { There should be procedures } \\
\text { for dealing with the failure of a market } \\
\text { intermediary in order to minimize damage } \\
\text { and loss to investors and to contain } \\
\text { systemic risk. }\end{array}$ & $\begin{array}{l}\text { The SCB has not developed an operational plan to deal } \\
\text { with the failure of a licensee as required by the Principle. } \\
\text { A National Crisis Management Plan is being drawn up } \\
\text { which will include securities firms and markets and will } \\
\text { become effective in the course of } 2013 \text {. Furthermore, the } \\
\text { absence of a specific liquidation procedure for market } \\
\text { intermediaries may cause legal uncertainty in returning } \\
\text { clients' assets in custody. }\end{array}$ \\
\hline $\begin{array}{l}\text { Principle } 33 \text {. The establishment of trading } \\
\text { systems including securities exchanges } \\
\text { should be subject to regulatory } \\
\text { authorization and oversight. }\end{array}$ & $\begin{array}{l}\text { There have been no applications to operate an exchange } \\
\text { or trading systems since BISX was set up in } 1999 . \\
\text { However, the licensing procedure appears } \\
\text { comprehensive and sufficient and includes written internal } \\
\text { review criteria and processes. }\end{array}$ \\
\hline
\end{tabular}




\begin{tabular}{|c|c|}
\hline $\begin{array}{l}\text { Principle } 34 \text {. There should be ongoing } \\
\text { regulatory supervision of exchanges and } \\
\text { trading systems which should aim to } \\
\text { ensure that the integrity of trading is } \\
\text { maintained through fair and equitable rules } \\
\text { that strike an appropriate balance between } \\
\text { the demands of different market } \\
\text { participants. }\end{array}$ & $\begin{array}{l}\text { The decision taken last year to carry out the first formal } \\
\text { on-site inspection of BISX was an important extension of } \\
\text { the SCB's supervisory activities. The inspection appears } \\
\text { to have been thorough and to have covered the key } \\
\text { elements of the exchanges operations. }\end{array}$ \\
\hline $\begin{array}{l}\text { Principle } 35 . \text { Regulation should promote } \\
\text { transparency of trading. }\end{array}$ & $\begin{array}{l}\text { The absence of a mechanism to provide pre- and post- } \\
\text { trade information on a real time base to investors } \\
\text { generally is a significant weakness in the BISX trading } \\
\text { platform given that the market is accessible to retail } \\
\text { investors and some listed companies have reasonably } \\
\text { significant numbers of retail shareholders. }\end{array}$ \\
\hline $\begin{array}{l}\text { Principle } 36 . \text { Regulation should be } \\
\text { designed to detect and deter manipulation } \\
\text { and other unfair trading practices. }\end{array}$ & $\begin{array}{l}\text { While the number of cases of market manipulation and } \\
\text { similar abuses are very low, this may be related to the } \\
\text { opportunities for abusive behavior in a market which is as } \\
\text { small and illiquid as this ( } 2-3 \text { trades a day) are very } \\
\text { limited and unusual transactions are easily detectable. } \\
\text { There appears to be no reluctance on the part of the SCB } \\
\text { to take administrative action or on the part of the Office of } \\
\text { the Attorney General to take criminal action when wrong- } \\
\text { doing is suspected. Sanctions for violations appear } \\
\text { effective, proportionate and dissuasive. }\end{array}$ \\
\hline $\begin{array}{l}\text { Principle } 37 \text {. Regulation should aim to } \\
\text { ensure the proper management of large } \\
\text { exposures, default risk and market } \\
\text { disruption. }\end{array}$ & $\begin{array}{l}\text { There is currently no large exposure monitoring system } \\
\text { with appropriate trigger points. This deficiency will be } \\
\text { addressed by end } 2012 \text {. There is no evidence that short } \\
\text { selling is undertaken in the equity market. }\end{array}$ \\
\hline $\begin{array}{l}\text { Principle } 38 \text {. Securities settlement systems } \\
\text { and central counterparties should be } \\
\text { subject to regulatory and supervisory } \\
\text { requirements that are designed to ensure } \\
\text { that they are fair, effective and efficient and } \\
\text { that they reduce systemic risk. }\end{array}$ & $\begin{array}{l}\text { Not assessed. Currently there is no securities settlement } \\
\text { system or central counterparty as contemplated by this } \\
\text { Principle. Settlement of securities traded on BISX takes } \\
\text { place at the Bahamas Central Securities Depository, } \\
\text { which is the register of corporate shares, and payment is } \\
\text { settled by delivery of cheques bilaterally between brokers } \\
\text { at the BISCX offices. }\end{array}$ \\
\hline
\end{tabular}




\section{Annex Table 6. The Bahamas: Recommended Action Plan to Improve Implementation of the IOSCO Principles}

\begin{tabular}{|c|c|}
\hline Principle & Recommended Action \\
\hline Principle 2 & $\begin{array}{l}\text { The decision to empower the SCB to raise more fees from its } \\
\text { licensees appears to be an appropriate and proportionate response } \\
\text { to the likely ongoing requirements of the SCB and should be } \\
\text { pursued by the SCB to an effective conclusion. }\end{array}$ \\
\hline Principle 8 & $\begin{array}{l}\text { The SCB should keep under review the degree to which licensees } \\
\text { and public issuers are effective in managing conflicts of interest and } \\
\text { in particular should remain alert for the growth of misaligned } \\
\text { incentives as have proved damaging to investors' interests in other } \\
\text { jurisdictions especially in light of market composition. }\end{array}$ \\
\hline Principle 9 & $\begin{array}{l}\text { Given the systemic role BISX plays as the only stock exchange in } \\
\text { The Bahamas, and given its gatekeeper role in that trading in } \\
\text { securities listed on BISX can only take place through its systems, } \\
\text { SCB should consider here, or under Principle } 34 \text {, whether the new } \\
\text { SIA can be interpreted to impose standards of behavior on BISX } \\
\text { which go beyond those that are required of licensees generally, and } \\
\text { more closely replicate those expected of the SCB including } \\
\text { governance, transparency and fairness. }\end{array}$ \\
\hline Principle 12 & $\begin{array}{l}\text { In the course of licensing an investment fund all related parties } \\
\text { should be subject by the SCB to a full due diligence check and not } \\
\text { just a "fit and proper" assessment. Managers/advisers, operators } \\
\text { and custodians should be subject to an ongoing level of oversight } \\
\text { (including on-site examinations) as is currently applied to } \\
\text { investment fund administrators. }\end{array}$ \\
\hline Principle 16 & $\begin{array}{l}\text { The SCB should keep the issue of resources under review in case } \\
\text { pressures arise as a result of enactment of the corporate } \\
\text { governance code and the takeover code in } 2013 \text { since these will } \\
\text { require public issuers to comply with (and to be assessed against) } \\
\text { additional obligations under the SIA as discussed under Principles } \\
16 \text { and } 17 .\end{array}$ \\
\hline Principle 18 & $\begin{array}{l}\text { BICA should consider developing an interpretive function in order to } \\
\text { assist auditors when questions specific to the situation in The } \\
\text { Bahamas arise. }\end{array}$ \\
\hline Principle 19 & $\begin{array}{l}\text { The Government should consider appointing a public interest } \\
\text { oversight body for the auditing profession and BICA. In a small } \\
\text { jurisdiction such as The Bahamas it is probably unnecessary, and } \\
\text { inefficient, to create such a body specifically for this task. } \\
\text { Consideration should be given to assigning the role to the SCB. }\end{array}$ \\
\hline Principle 22 & $\begin{array}{l}\text { Currently the SCB does not need to develop a regime for licensing } \\
\text { and the ongoing supervision of credit rating agencies. However, in } \\
\text { order to be fully compliant with this Principle the SCB needs to } \\
\text { demonstrate that in permitting the use of external credit ratings it } \\
\text { has made a reasonable judgment that the CRAs whose ratings are } \\
\text { permitted for use are subject to registration and oversight. }\end{array}$ \\
\hline
\end{tabular}




\begin{tabular}{|c|c|}
\hline Principle & Recommended Action \\
\hline Principle 23 & $\begin{array}{l}\text { Although at the current stage of development of the securities } \\
\text { market the present high level approach is probably sufficient, the } \\
\text { SCB may wish to consider, once the current round of consultations } \\
\text { has been completed and the resulting rules and guidance have } \\
\text { been introduced, developing guidance at the level of granularity } \\
\text { contemplated by IOSCO and as set out in the key questions to this } \\
\text { Principle. }\end{array}$ \\
\hline Principle 24 & $\begin{array}{l}\text { As part of the investment fund licensing process the SCB should } \\
\text { extend its "fit and proper" check on managers/advisers, promoters, } \\
\text { operators and custodians to an examination of their governance, } \\
\text { organization and operational conduct. } \\
\text { The SCB should subject related parties present in the jurisdiction to } \\
\text { the level of ongoing oversight it applies to investment fund } \\
\text { administrators. } \\
\text { The exclusion in the SIA which permits dealing in investment fund } \\
\text { shares for clients without a license as long as that is the only } \\
\text { securities dealing a person undertakes should be deleted. } \\
\text { Since } 98 \text { percent of funds are structured as companies the SCB } \\
\text { might wish to consider adding funds to the entities to be subject to } \\
\text { the Corporate Governance Code. } \\
\text { The SCB should complete its work on updating the IFA and IFR, } \\
\text { taking account of the standards of regulation of investment funds } \\
\text { and their related parties as currently established by IOSCO and } \\
\text { should seek to secure the necessary legislative amendments as } \\
\text { soon as possible. }\end{array}$ \\
\hline Principle 25 & $\begin{array}{l}\text { See recommendation to Principle } 24 \text { regarding updating the } \\
\text { investment funds legislation and regulations. }\end{array}$ \\
\hline Principle 26 & $\begin{array}{l}\text { See recommendation to Principle } 24 \text { regarding updating the } \\
\text { investment funds legislation and regulations. }\end{array}$ \\
\hline Principle 27 & $\begin{array}{l}\text { Among the amendments to be secured in the IFA and IFR as } \\
\text { referred to under Principe } 24 \text { should be requirements that fund } \\
\text { operators have and disclose mechanisms and processes for asset } \\
\text { valuation and the pricing and the redemption of units which can be } \\
\text { verified by the SCB and for deficiencies in which the SCB is able to } \\
\text { impose sanctions. }\end{array}$ \\
\hline Principle 28 & $\begin{array}{l}\text { SCB should keep the size, asset composition and trading strategies } \\
\text { of its professional and SMART funds under review with the } \\
\text { objective of determining whether, by virtue of size, leverage etc. any } \\
\text { would fall within the broad category of hedge fund for which } \\
\text { enhanced supervision is required. }\end{array}$ \\
\hline Principle 32 & $\begin{array}{l}\text { The SCB should develop a plan to deal with the failure of a licensee } \\
\text { as part of the National Crisis Management Plan currently being } \\
\text { developed. The authorities might consider introducing a broad- } \\
\text { based investor compensation scheme to supplement the BISX } \\
\text { scheme. }\end{array}$ \\
\hline
\end{tabular}




\begin{tabular}{|l|l|}
\hline \multicolumn{1}{|c|}{ Principle } & \multicolumn{1}{c|}{ Recommended Action } \\
\hline Principle 34 & $\begin{array}{l}\text { SCB should ensure that, going forward, it maintains its new } \\
\text { approach to supervising BISX with a regular program of on-site } \\
\text { inspections. }\end{array}$ \\
\hline Principle 35 & $\begin{array}{l}\text { SCB should require BISX to make public the details of trades (other } \\
\text { than block trades) as they occur rather than at the end of day. }\end{array}$ \\
\hline
\end{tabular}

\section{Authorities' ReSPOnSE TO THE ASSESSMENT}

69. The SCB is satisfied with the quality of the review undertaken by the Assessors and is in agreement with the overall assessment. Mr. Britton's patience and candour during the assessment and the level of professionalism exhibited, are greatly appreciated.

70. Subsequent to the visit, the SCB has implemented some aspects of the recommended changes. With respect to Principle 12, 24, and 25, where the Assessor notes that related parties such as managers/ advisors and custodians of investment funds should be subjected to greater oversight, the SCB has instituted, starting August 1, 2012, onsite inspections of domestic mangers/advisors and custodians. Additionally, the corporate governance paper, which is out for consultation, has been amended to set governance standards for CISs.

71. Similarly, with respect to Principle 35, the SCB, while noting that trading activity in the jurisdiction is weak, accepts the view that trading data should be published more frequently and has directed the BISX to have trade details publicly available within 15 minutes of the trade.

72. The SCB has also begun talks with key stakeholders to advance the weakness noted with respect to principles 18,19 , and 21 . The concerns raised about the weaknesses in the Funds legislation were already on the SCB's radar prior to the visit. In August, the SCB established an IFA review team, comprised of industry participants, to provide input and guidance on the industry's perspective about the required changes. Work has also continued on a number of projects initiated prior to the FSAP assessment, including the BISX oversight program, the guidance on asset valuation and the crisis management plan for SCB constituents.

73. The SCB has reviewed the recommendations and have embarked on a two-to-three year project to implement changes which should lead to full compliance with all of IOSCO's principles. Key projects being undertaken include, inter alia:

- $\quad$ finalizing all rules, guidelines and surveillance programs required for the full implementation of the SIA 2011, including disciplinary rules, takeover codes, corporate governance, regulatory capital, fees, liquidity and large and related party exposures rules, re-categorization of licenses and revamping of internal procedures; 
- working with other regulators, the Ministry of Finance and the Office of the Attorney General (OAG) to develop a crisis management plan for the jurisdiction. A crisis management seminar with a simulation exercise is scheduled for October 31, 2012;

- developing a full oversight program for BISX with detailed requirements which exceed those required of other licensees and ensures that the confidentiality requirements are in line with what would be required of a regulatory institution;

- $\quad$ establishing an oversight body for the Accounting community;

- $\quad$ repealing and replacing the legislation governing the investment funds industry and implementing the relevant oversight programs;

- $\quad$ finalizing database projects targeted to improve efficiency and effectiveness with respect to the oversight of licensees/registrants;

- $\quad$ working with the $\mathrm{CBoB}$ with respect to the creation of systems for clearing and settlements that are congruous, so that the requirements for securities settlements are met; and

- formally recognize those credit rating agencies to be used for the calculation of market risk in the regulatory capital methodology, identifying the underlying standards required for their recognition. 


\section{AnNeX IV: The Bahamas: Exchange and Capital ConTrols}

\section{Bona fide current account transactions in The Bahamas are liberalized and} largely delegated to be transacted, within generous limits, by commercial banks against proper documentation. These include payments for personal and business travel, imports and credit cards, and for sundry payments (such as advertising professional service charges, educational and medical expenses, etc.).

75. The CBoB maintains restrictions on capital flows in order to ensure monetary and financial stability and manage pressures on the peg. There are two exchange markets: the official exchange market and the investment currency market, with the latter currently requiring a premium of 12.5 percent over the official exchange rate for outward payments and providing a premium of 10 percent for the repatriation of the originally approved capital investment. ${ }^{2}$ The repatriation back to The Bahamas of income and capital gains over and above the initial investment amount must be converted at the official rate.

\section{Capital and money market instruments}

- All outward capital transfers require exchange control approval, and outflows of resident-owned capital are restricted. Inward transfers by non-residents must be processed through the exchange control approval procedure.

\section{Shares or other securities}

- $\quad$ Outward investments by residents require permission from the $\mathrm{CBoB}$, and they are normally processed through the investment currency market. Pension funds, including the National Insurance Board (NIB), require CBoB approval to invest in securities issued by non-residents or in an investment portfolio held abroad (see below).

- Inward investment by non-residents is unrestricted in size, but CBoB approval is required for the issue or transfer of shares or control in a Bahamian company to a nonresident. Investments in equities of companies listed on The BISX are restricted to a limit of 10 percent of the issue or offering for each investing entity. Cross listing of Bahamian and foreign companies on CARICOM stock exchanges is allowed, subject to specified limits.

\footnotetext{
${ }^{2}$ The current so-called premium bid and offer rates of 12.5 percent and 10 percent have been in effect since January 2006, when they were reduced from their previous levels of 25 percent and 20 percent, respectively.
} 


\section{Controls of credit operations}

- $\quad$ Resident banks and other lenders must have permission to extend loans in Bahamian dollars to any corporate body controlled by non-residents. Resident companies wholly owned by non-residents are not allowed to raise fixed capital in Bahamian dollars, although those partially owned by residents may borrow in Bahamian dollars for fixed capital purposes to the extent of their resident ownership. Resident companies set up by non-residents are not normally permitted to participate in the wholesale/retail distribution sector.

- $\quad$ Residents other than authorized banks must obtain permission to borrow foreign currency from non-residents or to service foreign currency loans by converting Bahamian dollars. Exchange control approval is required if local real estate is offered as collateral.

- Commercial banks and other credit institutions require exchange control approval to make loans to residents in foreign currency, or to extend loans to non-residents using local real estate as collateral.

\section{Direct investment}

- Inward direct investment requires $\mathrm{CBoB}$ approval. Regarding outward direct investments for residents, the use of the official exchange market is limited to US\$1 million per person or entity, with an overall limit of US\$5 million per transaction, every three years, in cases which are judged as special criterion, i.e.,ventures that promise positive returns to the Balance of Payments within a reasonable time-frame (e.g., three years). While the Central Bank may, at its discretion grant approval for amounts in excess of the allowable limit all other outward direct investments must be funded through the Investment Currency Market or combination of funding, e.g., foreign currency borrowing.

- $\quad$ Recognizing the desirability to provide diversification opportunities for the NIB's investments portfolio, the NIB is permitted to make overseas investments of up to US\$25 million per year at the official exchange rate. Bahamian employees of foreignowned institutions in The Bahamas may invest up to US $\$ 25,000$ per year at the official exchange rate in the shares of their employer as part of an employer-provided benefits program ("employee stock options"), subject to CBoB approval. Amounts above this limit would need to be transacted through the investment currency market.

\section{Real estate}

- $\quad$ Residents require approval from the $\mathrm{CBoB}$ to buy property abroad and face the premium of 12.5 percent on approved purchases. However, residents are permitted, once every ten years, to make an investment of US\$25,000 at the official exchange 
rate for the purposes of purchasing a timeshare real estate property interest. Amounts above US $\$ 25,000$ would need to be transacted through the investment currency market. Non-residents intending to purchase land for commercial purposes or property larger than five acres must obtain a permit from the Investments Board. Non-residents intending to buy properties for residential purposes need to obtain a certificate of registration from the Investments Board on completion of the transaction.

- $\quad$ Remittance abroad of the proceeds of sale of properties in The Bahamas by nonresidents requires approval from the $\mathrm{CBoB}$. On completion of the real estate transaction and on presentation of the required permits and registration documents, the $\mathrm{CBoB}$ issues an "Approved Investment Status" certificate to non-residents for their real estate investment in The Bahamas, which provides them with the assurance that when they wish to sell their property, they will be able to repatriate all the funds (including capital gains) at the official exchange rate.

\section{Emigration}

Bahamians taking permanent residency abroad are allowed to transfer abroad US $\$ 250,000$ per family per year at the official exchange rate, subject to $\mathrm{CBoB}$ approval. Amounts above these annual limits would need to be transacted through the investment currency market or may otherwise be permitted at the Bank's discretion. 